MARKETING WITH EMOTION, COMMUNICATING WITH REASON: A COMPARISON OF GOOGLE'S CONSUMER-BRAND ENGAGEMENT STRATEGIES BY AD EXECUTION FORMAT

\author{
by \\ Vanessa To \\ BA, Simon Fraser University, 2015 \\ A Major Research Paper \\ presented to Ryerson University \\ in partial fulfillment of the \\ requirements for the degree of \\ Master of Professional Communication
}

Toronto, Ontario, Canada, 2017

(C) Vanessa To, 2017 


\section{Author's Declaration for Electronic Submission of a Major Research Paper}

I hereby declare that I am the sole author of this Major Research Paper. This is a true copy of the MRP, including any required final revisions, as accepted by my examiners.

I authorize Ryerson University to lend this MRP to other institutions or individuals for the purpose of scholarly research.

I further authorize Ryerson University to reproduce this MRP by photocopying or by other means, in total or in part, at the request of other institutions or individuals for the purpose of scholarly research.

I understand that my MRP may be made electronically available to the public. 


\title{
MARKETING WITH EMOTION, COMMUNICATING WITH REASON: A COMPARISON OF GOOGLE'S CONSUMER-BRAND ENGAGEMENT STRATEGIES BY AD EXECUTION FORMAT
}

\author{
Vanessa To \\ Master of Professional Communication \\ Ryerson University, 2017
}

\begin{abstract}
This Major Research Paper (MRP) studies how emotional marketing influences brand storytelling and aims to recognize why the tactic is considered effective for driving consumer-brand engagement. Current literature one motional marketing has had limited attention by researchers. This study expands the research available to marketers, advertisers, and communication professionals. To pursue the research, this study focuses on Google's online advertisements, Dear Sophie (2011) and Your Chrome, Everywhere (2012), each of which use different ad execution formats for analysis; the former by emotion and the latter by reason. Following a two-part comparative and multimodal analysis, three major findings appear from the research. First, ad execution by emotion generates increased consumer-brand engagement, in comparison to ad execution by reason. Second, ad execution by reason appears to be more valuable for actionable consumerbrand interaction. Lastly, there is indication that ad execution format by positive emotion influences a response of positive consumer-brand attitude. This study concludes with suggestions for future research on emotional marketing.
\end{abstract}




\section{Acknowledgments}

It is with sincere gratitude that I acknowledge the individuals who contributed to this major research paper, and provided support throughout the course of the master's program.

To my advisor, Dr. Frauke Zeller, thank you for your time, this experience, and the continuous learning opportunities. To my second reader, Dr. John Shiga, thank you for sharing your expertise.

Lastly, to my partner, Nicholas LeRose, whom I'm especially grateful for. Thank you for providing me with optimism, confidence, and perhaps most importantly, perspective. 
Dedication

To my parents,

Whose support means everything to me.

Thank you. 


\section{Table of Contents}

\section{A. Front Matter}

Author's Declaration.............................................................................. page $\mathrm{i}$

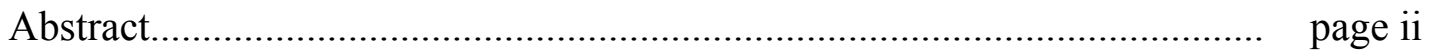

Acknowledgements........................................................................ page $\mathrm{iii}$

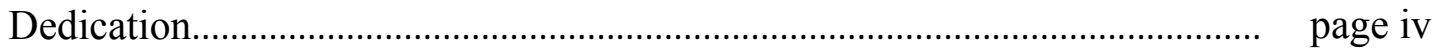

Table of Contents......................................................................... page $\mathrm{v}$

List of Tables......................................................................................... page vii

List of Appendices........................................................................... page viii

\section{B. Main Body}

1. Introduction

page 01

2. Literature Review

page 03

2.1 Emotional Marketing

page 04

2.2 Marketing and Communications

page 09

2.3 Multimodality

page 11

2.4 Research Questions

page 15

3. Research Method

page 16

3.1 Data Collection Method

page 16

3.2 Method of Analysis

page 17

4. Findings and Discussion

page 23

4.1 Part I: Comparative Analysis - Discussion of Results page 24

4.2 Part I: Comparative Analysis - Interpretation of Findings page 27 
4.3 Part II: Multimodal Analysis - Discussion of Results

page 37

4.4 Part II: Multimodal Analysis - Analysis of Findings

page 40

5. Conclusion

page 47

5.1 Significance of Findings

page 47

5.2 Limitations and Implications

page 50

5.3 Concluding Remarks

page 52

Reference List

page 53

\section{Back Matter}

Appendix A.

page 58

Appendix B

page 65

Appendix C.

page 67

Appendix D

page 69

Appendix E

page 79

Appendix F

page 89

Appendix G

page 90 


\section{List of Tables}

Table 3.1: Comparative Analysis - Coding Criteria.......................................... page 19

Table 3.2: Comparative Analysis - Additional Criteria..................................... page 20

Table 4.1: Comparative Analysis - Summary of Results.................................. page 26

Table 4.2: Comparative Analysis - Vanity Metrics.......................................... page 27

Table 4.3: Dear Sophie (2011) Sample Data Collection........................................ page 31

Table 4.4: Your Chrome, Everywhere (2012) Sample Data Collection.................... page 32

Table 4.5: Dear Sophie (2011) - Summary Analysis of Shots and Phases.............. page 38

Table 4.6: Transcription of Dear Sophie (2011) - Summary Analysis.................... page 45 


\section{List of Appendices}

Appendix A. Part I: Comparative Analysis - Data Set Evaluation......................... page 58

Appendix B. Part I: Comparative Analysis - NVivo Final Coding........................ page 65

Appendix C. Part I: Comparative Analysis - Vanity Metrics................................ page 67

Appendix D. Part I: Comparative Analysis - Dear Sophie (2011) Data Set............ p page 69

Appendix E. Part I: Comparative Analysis - Your Chrome, Everywhere (2012)

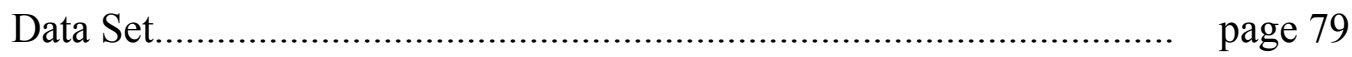

Appendix F. Part II: Multimodal Analysis - Transcription Codebook...................... page 89

Appendix G. Part II: Multimodal Analysis - Transcription of Google's Dear

Sophie (2011) Advertisement......................................................... page 90 


\section{INTRODUCTION}

Strong brand narratives tell compelling stories of meaning and experience, stimulating both imagination and feelings that encourage us to feel something in connection to a brand (Granitz \& Forman, 2015; Herskovitz \& Crystal, 2010; Lundqvist, Liljander, Gummerus, \& Riel, 2013). With powerful storytelling, brands are able to engage with consumers and inspire an attached emotional response. These concepts of marketing with emotion lend meaning to how a brand can come to life through emotional connection and, with this, establish a relationship of brand loyalty (Gobé, 2009). Studies within the discipline of marketing and communications address how brand storytelling and emotional marketing work together to reach a position of brand loyalty. As follows, this major research paper (MRP) intends to distinguish how emotional marketing influences brand storytelling and to recognize why the tactic is considered effective for driving consumer-brand engagement. Specifically, the intention is to understand how emotive meaning in visual images is used in global marketing campaigns. Thus, the analysis part of this MRP will focus on Google's brand storytelling as its 2011 marketing strategy relates to emotional branding.

On September 2, 2008, Google (2008) introduced Google Chrome, a simplified, user-friendly open source web browser. In 2011, Google partnered with marketing and advertising agency Bartle Bogle Hegarty $(\mathrm{BBH})$, to produce a creative campaign to advertise the browser and grow the brand. This was 
Google's first extensive offline marketing initiative, promoting Chrome through a national TV media buy followed by extended online communications with banners, and an interactive YouTube video series (Bartle Bogle Hegarty, 2015). Together, $\mathrm{BBH}$ and the Google Creative Lab brought The web is what you make of it to life, in a three-part television and online advertising campaign featuring short clips titled, Dear Sophie, Lady Gaga, and It Gets Better. The campaign takes a strategic turn from marketing functionality to sentimentality, positioning Chrome as a tool that can be used by the everyday person (Bartle Bogle Hegarty, 2015). Drawing on an emotional theme, Google captures the real-life functions of what Chrome can be used for with an interactive tour of the platform's extensions. The advertisements explore Gmail, YouTube, Google Maps, and more. Much to the campaign's title, the concept behind Google's tactic is simple, that the web is really what you choose to make of it (Bartle Bogle Hegarty, 2015). Google's approach to brand storytelling is in creating a campaign that shows viewers how choosing Chrome has changed lives. Behind each story, is a life made better with Google Chrome.

Of the three-part campaign, this MRP intends to focus on Dear Sophie (2011), the first advertisement that launched. In a brief narration, Dear Sophie tells the story of a father who uses Chrome to develop a digital scrapbook to chronicle his daughter's childhood. The advertisement shows a progression of vignettes put together entirely from screenshots, subject lines, keystrokes and 
clicks, moving to a soft piano composition. With each frame, Dear Sophie brings the brand to life outside of the computing world, where technology meets humanity. Google strategically creates a narrative that is relatable although unfinished, and thus, left to imagination. Dear Sophie allows the audience to continue the narrative by finding relation to their own life's story. This lasting impression, which develops from using emotion to tell a brand's story, is central to this MRP.

\section{LITERATURE REVIEW}

The following literature review will discuss the current state of research around the use of emotions in marketing and communications, in support of the research focus on emotional marketing as a strategy for brand storytelling. Over the past decade, our market has seen a shift towards redefining the meaning of a fulfilling brand concept, followed by an increased recognition for the role that cognitive processes play in shaping a consumer's perception of a brand's identity (Bagozzi, Gopinath, \& Nyer, 1999; Gobé, 2009; Robinette, Brand, \& Lenz, 2001; Soscia, 2013). Motivation for human behaviour has moved from rational to emotional stimuli to drive branding decisions (Gobé, 2009; Papadatos, 2006; Rytel, 2010). Accordingly, brand storytelling has become less about marketing function and more about placing emphasis on the aesthetic and emotional qualities of a brand. Therefore, the literature review will focus on three major 
themes to meet the objectives of this study:

1. Emotional Marketing

2. Marketing and Communications

3. Multimodality

These areas of research provide a framework for understanding how emotions are used to tell a brand's story and why the marketing strategy is considered an effective driver of consumer-brand engagement. The literature review will define emotional marketing within the field of marketing and communications, and establish a theoretical understanding of a multimodal approach to further analyze the concept and its use in brand storytelling.

\subsection{Emotional Marketing}

This component of the literature review helps to define emotional marketing. It is essential for outlining the scope of study and to identify the limitations of research for this MRP. The study of emotional marketing extends across many disciplines inclusive of advertising, business, communications, marketing, psychology and sociology. For the purpose of this research paper, emotional marketing will be defined primarily within the field of marketing and communications, and consider secondary disciplines.

To begin, behavioural and marketing studies define emotion by response categories and in relation to branding purposes. There are variations of emotions 
that are considered as universal or fundamental and, with this, produce predictable reactions (Chaudhuri, 2006; Dobele, Lindgreen, Beverland, Vahamme, and van Wijk, 2007; Fox, 2008; Soscia, 2013). From a cognitive and neuroscientific approach, there are four distinct categories of emotion: happiness, sadness, fear, and anger (Fox, 2008; Jack, Garrod, Schyns, 2014). Similarly, in marketing research, there are six primary emotions identified as surprise, joy, sadness, anger, fear, and disgust (Chaudhuri, 2006; Dobele et al., 2007; Soscia, 2013). Scientific studies on emotions, group these distinctions further into opposing categories of positive versus negative emotions. In this view, positive emotions are likened to pleasant experiences, whereas negative emotions are considered to be unpleasant, and can be measured as either a good or bad reaction (Bagozzi et al., 1999; Fox, 2008; Yoo \& MacInnis, 2005). Such references see emotions of happiness and joy to be positive and responses of sadness, anger, and fear to be negative (Bagozzi et al., 1999; Fox, 2008; Yoo \& MacInnis, 2005).

Moving away from discrete categories, additional literature reference the theory and function of emotions. Bagozzi et al. (1999) focus on the state of readiness that is extended by felt subjective experiences, physiological response, and bodily expression. Grisaffe and Nguyen (2011;2010;) provide coding and categories of superior marketing characteristics, traditional customer outcome states, unique user-derived benefits, socialization forces and sentimentality or emotional memory. O'Shaughnessy and O'Shaughnessy (2003) distinguish 
emotions as either being factive, as in "grounded in belief" (p.81) or epistemic, meaning "pertaining to knowledge" (p.86). Lastly, Huang (2001) discusses the use of emotions in advertising through defining characteristics in psychology and marketing as understood with corresponding theoretical proposals. While there is literature specific to identifying what factors motivate emotions in marketing, there are also limitations posed across many studies stating that emotions are difficult to measure, considering human sensitivity to personal and contextual factors (Akhün et al., 2013; Bagozzi et al., 1999; Fox, 2008; Soscia, 2013). As well, there are few studies focused on the unintended consequences of emotional branding (Thompson, Rindfleisch \& Arsel, 2006). With this, marketing research on emotional response is wide-ranging.

Further, literature that references emotional marketing define the concept with regards to terms alike, such as emotion, emotional branding, and emotional sentiment. Additional key terms associate emotional marketing by purpose, relating the concept to trust, brand loyalty, and brand sentiment; this will be addressed in the second part of the literature review. The purpose of defining emotion is to provide structure for the interpretation of emotional behaviour and accompanying reactions. Aforementioned, behavioural research by Bagozzi et al. describe the term 'emotion' as "mental states of readiness that arise from appraisals of events or one's own thoughts" (1999, p.184). This leads to the understanding that emotions are attached to recognizable behavioural and 
physiological responses, which are observable in facial expressions and bodily movements (Bagozzi et al., 1999; Fox, 2008). In this view, additional studies place emphasis on the inconsistent uses of the terms affect, emotions, mood, and attitudes, which contradicts literature that associates emotion with passion, affect, affection, and feelings (Balgaradean, 2015; Bagozzi et al., 1999; Fox, 2008; Soscia, 2013). Turning to 'emotional branding', researchers offer definitions that associate emotion to lasting connections with a brand (Akgün, Koçoğlu, \& İmamoğlu, 2013; Gobé, 2009; Rytel, 2010). This reference describes consumer engagement with a brand as relating to terms of intimacy, sensation, and satisfaction. This ties into 'emotional sentiment', otherwise perceived as having feelings of strong positive brand fondness, which is linked to the overall purpose of the branding strategy (O'Shaughnessy \& O'Shaughnessy, 2003). Altogether, reference to emotional marketing is defined in the context of contemporary marketing as a branding practice that focuses on the emotional connection between brands and consumers. The term represents a branding approach that goes beyond material satisfaction and reaches emotional fulfillment, thus establishing a strong relationship with the consumer as a brand partner (Gobé, 2009; Rytel, 2010). Studies involving emotional marketing are primarily found in research related to consumer behaviour and consumption, as well as strategies that drive consumer-brand relationships. 
Additional literature on emotional marketing points to how the approach can be used in branding strategies. Research in business and marketing address the function of emotions in how an advertisement (ad) format is executed, from type of appeal to execution style. Yoo and MacInnis (2005), amongst supporting authors and researchers, distinguish the two formats as ad execution by reason versus ad execution by emotion. Within brand advertising, a format of reason is designed to communicate a service or product's rational, informational, and functional aspects, using objective information to explain a brand's attributes or benefits to the consumer (Chaudhuri, 2006; O'Shaughnessy \& O'Shaughnessy, 2003; Rytel, 2010; Yoo \& MacInnis, 2005). When the ad execution is informational the aim is to persuade with reason, using "knowledge by description" (Chaudhuri, 2006, p.3). Therefore, the focus of the advertisement is to provide evidence of the tangible benefits and features, such as, of a brand's efficiency, practicality, or affordability (O'Shaughnessy \& O'Shaughnessy, 2003). By contrast, a brand storytelling ad format serves to stimulate an emotional experience through focusing on the relational and participatory features of a brand (Rytel, 2010; Yoo \& MacInnis, 2005). Specifically, an emotional ad format is characteristically designed from a "narrative process of antecedents, such as relevant stimuli, wants, and beliefs that [give] rise to the emotional experience" (O'Shaughnessy \& O'Shaughnessy, 2003, p.35). When the ad execution is emotional the intention is to sell the brand rather than the product, using 
"knowledge by acquaintance" (Chaudhuri, 2006, p.3); this is the essence of brand storytelling. The advertisement uses an emotional format to influence brand attitudes that are driven by feeling responses and, therefore, develops a connection between the brand and the consumer (Yoo \& MacInnis, 2005). Essentially, the type of appeal and execution format is defined by the underlying purpose of an advertisement to influence consumer decision-making, and thus, the extent of engagement and interaction with the brand.

Research on emotional marketing appear in studies that focus on measuring the degree of impact and effectiveness (Akbari, 2015), the nature of response as positive or negative (Yoo \& MacInnis, 2005), and additional contributing factors, such as, culture or gender (Albers-Miller \& Stafford, 1999; Doebel et al., 2007). These studies have been both qualitative and quantitative in nature, using quasi-experimental methods (Akbari, 2015), stimulus selection and questionnaires (Yoo \& MacInnis, 2005), surveys and interviews (Doebel et al., 2007), or content analysis (Albers-Miller \& Stafford, 1999; Grisaffe \& Nguyen, $2011 ; 2010 ;)$.

\subsection{Marketing and Communications}

There are two primary areas of focus that appear in the literature of emotional marketing and within the field of marketing and communications: brand storytelling and brand loyalty. In this section of the literature review, the 
aforementioned associated key terms of trust, brand loyalty and brand sentiment are addressed, as each relate to the discussion of the two focuses.

Brand storytelling enables the consumer-brand relationship that emotional marketing helps to create, shifting the consumption experience from being individual to collective (Granitz \& Forman, 2015; Lundqvist et al., 2013; Pera \& Viglia, 2016). In marketing and communications literature, storytelling is recognized as essential to successful branding by giving way to a deeply-felt and long-lasting emotional bond that is relatable and consistent with an audience's needs and attitudes (Herskovitz \& Crystal, 2010). Although there are many studies written about the power of brand storytelling, there are only few that link emotional marketing to the practice. Across these studies, emotional attachment is considered central to brand storytelling (Lundqvist et al., 2013) and there is emphasis that emotional memory stores positive emotions factually and visually (Pera \& Viglia, 2016). This is where the importance of understanding human nature comes to play, to tap into the innate characteristics that motivate emotions that intensify consumer wants and desires. Gobé (2009) and Thompson et al. (2006) suggest that branding strategies should shift focus to telling stories that respond emotionally to life experiences in a genuine and reflective manner, to mark the brand as enriching to a consumer's life. O'Shaughnessy and O'Shaughnessy bring emotional marketing and brand storytelling together in establishing that "emotion is the adhesive that, when mixed with trust, equals 
loyalty" (2003, p.5). Ultimately, brand loyalty is the underlying objective to gain devoted brand partners (consumers), profit and repurchasing (Grisaffe \& Nguyen, 2011; 2010;).

Marketing and communications studies focus on the role of emotional marketing in brand storytelling by measuring the relationship experience, the effect on consumer response, and the types of brand stories consumers want to hear. Additional literature addresses brand storytelling in the digital age, with studies around which media consumers want to find their stories and how to communicate on these platforms. Research in this area of focus have been primarily qualitative in nature, using in-depth interviews (Granitz \& Forman, 2015; Lundqvist et al. 2013), comparative analysis (Lundqvist et al. 2013), or a multi-method approach (Pera \& Viglia, 2016). The underlying purpose across these studies looks at recognizing the meanings across a brand's story and finds the linkages to the consumer-brand relationship experience.

\subsection{Multimodality}

The final section of this literature review ties the first two themes of focus together, in discussing multimodality as a framework for analyzing emotional marketing in brand storytelling. O'Halloran (2008) and Jewitt (2009) are amongst known scholars of multimodality that approach communication and representation in a more visual manner, to demonstrate how digital technologies are 
transforming the communicational landscape through sound, image, and movement. A multimodal framework takes into account function and meaning, and considers, "the full range of communicational [modes] people use - image, gesture, gaze, posture, and so on - and the relationships between them" (Jewitt, 2009, p.14). The term 'multimodal' recognizes that, when taken together, these communicative modes construct meaning (Baldry \& Thibault, 2006; Machin, 2007; O'Halloran, 2004). With this, a social semiotic multimodal approach allows for an analysis of, "interpersonal meaning, to present the world in specific ways, and to realize coherence" (Jewitt, 2009, p.29). As such, multimodality guides meaning making with rules and principles for analysis, by which the framework acts as a multipurpose toolkit (Baldry \& Thibault, 2006; Machin, 2007).

Central to multimodal analysis is the process of transcription, to pinpoint characteristic patterns that make meaning (Baldry \& Thibault, 2006; Baldry, 2004). Multimodal analysis considers all semiotic modalities as a whole, rather than taking meaning from separate semiotic selections (Baldry \& Thibault, 2006). The process of transcription is defined by "a set of co-patterned semiotic selections that are co-deployed in a consistent way over a given stretch of text" (Baldry \& Thibault, 2006, p.47). Thus, multimodal transcription allows researchers to capture the "activities, people, objects and circumstances represented in a television advertisement, in such a way that an advertisement's basic message can be reconstructed" (Baldry \& Thibault, 2006, p.49). The aim of 
this approach is to emphasize patterns that make up the functioning parts and give meaning to a larger whole.

In applying multimodal transcription to TV advertisements, Baldry and Thibault (2006) outline the components for analysis, taking into account the participants and chosen setting, as well as factors of time, sound, image, gesture, text and language. Particularly, the transcription of images, such as video stills, focus on the researcher's intent to, “depict the visual characteristics of people, objects and places, and relationships between them, as well as sequences of action" (Bezemer \& Mavers, 2011, p.199). The technique adopts a chronological frame-based dissection of linguistic, musical, and pictorial modes to reconstruct meaning (Baldry \& Thibault, 2006). With this, two methods for frame extraction are discussed as either following a fixed time-per-second correlation (Baldry, 2004) or through partial selection (Bezemer \& Mavers, 2011). The latter option involves selection criteria that are set by the researcher, based on analytical and rhetorical purposes (Baldry, 2004; Baldry \& Thibault, 2006; Bezemer \& Mavers, 2011). As a whole, multimodality provides a framework by which the combination of visual and auditory modes in a genre can be analyzed, to show what patterns exist and the overall meaning this elicits.

Multimodal analysis is a particularly useful approach for studying the genre of advertising (Del Saz-Rubio \& Pennock-Speck, 2009). As a method that considers non-verbal stimuli together with verbal messages in the process of 
meaning making, multimodal analysis captures the reliance of images and sound in advertising (Baldry, 2004; Del Saz-Rubio \& Pennock-Speck, 2009). Specifically, for the study of marketing with emotions in a TV advertisement, the transcription format provides a closer look at the interaction between the ad and the audience. The frame-by-frame dissection follows a tagging system to indicate where, what, when, and how often an emotion is used throughout an advertisement to establish the brand's identity and value (Baldry, 2004). Together with a user response analysis, a multimodal analysis allows an understanding of how emotions in marketing affect an emotional reaction in return.

Research around multimodal analysis specific to using the method to study digital narratives is fairly limited. Within this limitation, the case studies provided are specific to the discipline of education rather than marketing and communications. However, there are several authors who apply methods that are useful to reference for this study. Baldry and Thibault (2006), Honeyford (2013), and Lim and O'Halloran (2012) discuss systemic functional multi-discourse analysis, phasal analysis, critical discourse analysis, literary analysis, and visual analytic framework development. Wang (2016) uses a comparative and systemic functional analysis. Beyond this, Dash, Patnaik, and Suar (2016) follow Kress and Van Leeuwen's inter-semiosis framework, using content analysis and a multidiscourse analysis. 


\subsection{Research Questions}

This MRP aims to discuss emotional marketing in brand storytelling and attempts to identify why the tactic is considered effective for driving consumerbrand engagement. Based on current literature, this research paper considers the argument that, "emotional positioning is inherently superior to positioning your brand only on rational attributes" (Chaudhuri, 2006, p.29), and intends to explore this statement. The literature review discussed the power of emotion and its relevance within the field of marketing and communication. Further, the literature review addressed multimodality as a measurable framework to which the intended research questions appear feasible.

The first area of research will focus on why emotional marketing is considered an effective tactic, by evaluating user's reactions. The purpose is to gauge the nature of response attached to an emotionally formatted advertisement, in comparison to a rationally formatted advertisement.

RQ 1: What is the nature of response to Google's emotional marketing strategy from the YouTube advertisement, Dear Sophie (2011), posted on the brand's Google Chrome account?

RQ 1(a): Given the difference in ad format, what consumer-brand connections are evident in Google's Dear Sophie (2011) advertisement, in comparison to Google's Your Chrome, Everywhere (2012) advertisement? 
The second area of research will consider the fundamentals of emotional marketing and develop reasoning for its use as a branding strategy. The intention is to demonstrate how the tactic is integrated within a global marketing strategy, particularly Google's Dear Sophie (2011) online advertisement. Taking a multimodal approach, the objective is to identify what patterns exist to create meaning within a marketing campaign that uses emotion to tell the brand's story.

RQ 2: How is emotional marketing used in Google's Dear Sophie (2011) advertisement, to tap into feelings that encourage viewers to use Chrome?

\section{RESEARCH METHOD}

This section of the MRP outlines the proposed research methods to study how and why emotional marketing in brand storytelling is considered an effective marketing strategy. In the following sections, the process for data collection as well as the method of analysis is presented.

\subsection{Data Collection Method}

This research paper intends to study how emotion is used in a global marketing campaign. To address the research questions, the data will be collected using several methods, which contribute to a two-part analysis.

First, the study will take a comparative analysis of the emotional meanings and connections that are evident in Google's advertisements, Dear Sophie (2011) 
and Your Chrome, Everywhere (2012). Both advertisements are shared on Google Chrome's official YouTube channel. Therefore, the data will be collected using the YouTube Comment Scraper to pull all user-generated comments from each video. The data will then be imported into NVivo to sort user response groupings into node categories; this allows the data from each advertisement to be coded for observation and analysis. For additional comparison, the analysis will look at vanity metrics inclusive of total number of views, likes, dislikes, and comments for each ad format. To provide precise figures for comparison and further discussion, a screenshot of each advertisement will be captured at the time of data collection and then recorded in a table.

Next, to understand the function and meaning of emotions as a marketing tactic, a multimodal analysis will be prepared. This part of the study primarily focuses on Google's Dear Sophie (2011) advertisement for its emotional ad format. To collect the data, the video will be downloaded from YouTube where Google first shared the advertisement. From here, the video will be transcribed frame-by-frame in a spreadsheet and organized by codebook headings for further interpretation and analysis.

\subsection{Method of Analysis}

Aforementioned, this study will take place as a two-part analysis and apply methods that are both qualitative as well as quantitative in nature. The first 
part follows a comparative analysis to understand how emotional marketing influences brand storytelling and to recognize why the tactic is considered effective for driving consumer-brand engagement. The analysis will compare Google's advertisements, Dear Sophie (2011) to Your Chrome, Everywhere (2012). Both online advertisements are similar in length, content (promotion of Google Chrome), and production date; yet, each advertisement differs by tactic. Dear Sophie focuses on brand storytelling by marketing with emotion and Your Chrome, Everywhere emphasizes brand advertising through communicating with reason. The difference in ad execution format is essential to this study. With this, a comparative analysis is intended to reveal how user engagement and interaction differs by each ad format.

To define a measurable outcome, the analysis will consider consumer to brand connections based on user-generated feedback provided in the comments section of each online video. The research method involves cataloging user comments by the nature of response as reactional, non-reactional, or other; this is outlined in Table 3.1. From here, comments will be further grouped by subcategories of emotional response as being positive, negative, or neutral, and in consideration of other response types of foreign languages, non-related content or non-legible spam. Additional criteria for blank, duplicate, and multiple comments, as well as user to user replies, is also noted in Table 3.2. 
Table 3.1: Comparative Analysis - Coding Criteria

\begin{tabular}{|c|c|}
\hline $\begin{array}{l}\text { Coding Groups } \\
\text { and Subcategories }\end{array}$ & Criteria \\
\hline $\begin{array}{l}\text { 1. Reactional } \\
\text { 1A. Positive } \\
\text { 1B. Negative } \\
\text { 1C. Neutral }\end{array}$ & $\begin{array}{l}\text { The comment elicits an emotional reaction, ranging from } \\
\text { happiness, surprise, joy, sadness, anger, fear, or disgust } \\
\text { (Chaudhuri, 2006; Dobele et al., 2007; Soscia, 2013). } \\
\text { Subcategories will consider corresponding emotional } \\
\text { reactions as positive or negative - otherwise viewed as } \\
\text { good-bad, pleasant-unpleasant (Bagozzi et al., 1999; Fox, } \\
\text { 2008; Yoo \& MacInnis, 2005). Responses of this nature } \\
\text { indicate engagement towards the advertisement or the } \\
\text { brand, rather than specific to the product itself. An } \\
\text { additional category of 'neutral' is available, for responses } \\
\text { in reference to the video advertisement, with no attached } \\
\text { emotion; this includes comments such as, "I don't get it". }\end{array}$ \\
\hline $\begin{array}{l}\text { 2. Non-Reactional } \\
\text { Subcategories are } \\
\text { not applicable. }\end{array}$ & $\begin{array}{l}\text { The comment elicits an informational reaction and serves } \\
\text { a functional purpose. Responses of this nature indicate } \\
\text { engagement towards the product/service, rather than } \\
\text { specific to the advertisement or brand itself; this includes } \\
\text { comments such as, "tell me how to get rid of the refusal } \\
\text { to allow me to now add any account." Users reference the } \\
\text { product's tangible benefits and features, such as, of a } \\
\text { brand's efficiency, practicality, or affordability } \\
\text { (O'Shaughnessy \& O'Shaughnessy, 2003). }\end{array}$ \\
\hline $\begin{array}{l}\text { 3. Other } \\
\text { 3A. Foreign } \\
\text { Language } \\
\text { 3B. Non-Related } \\
\text { Content } \\
\text { 3C. Non-Legible } \\
\text { Spam }\end{array}$ & $\begin{array}{l}\text { The comment is unrelated or unsolicited. Responses of } \\
\text { this nature comments shared in languages other than } \\
\text { English, unconnected subject matters, and random } \\
\text { symbols or alphabets placed together. The non-related } \\
\text { grouping includes user to user responses, where } \\
\text { comments provided are directed to another user, rather } \\
\text { than user to advertisement engagement. }\end{array}$ \\
\hline
\end{tabular}


Table 3.2: Comparative Analysis - Additional Criteria

\begin{tabular}{|c|c|c|}
\hline Comment Type & Definition & Criteria \\
\hline Blank Comments & $\begin{array}{l}\text { The comment field is } \\
\text { empty. Blank data is not } \\
\text { codable on NVivo. }\end{array}$ & $\begin{array}{l}\text { Blank comments will be } \\
\text { removed from the data set. }\end{array}$ \\
\hline $\begin{array}{l}\text { Duplicate } \\
\text { Comments }\end{array}$ & $\begin{array}{l}\text { The comment is repeated } \\
\text { by the same user. } \\
\text { For example: } \\
\text { Comment 1: Google really } \\
\text { did live up to its motto! } \\
\text { Comment 2: Google really } \\
\text { does live up to its motto. }\end{array}$ & $\begin{array}{l}\text { Duplicate comments will } \\
\text { only include one comment } \\
\text { in the data set. }\end{array}$ \\
\hline $\begin{array}{l}\text { Multiple } \\
\text { Comments } \\
\text { (Consecutive) }\end{array}$ & $\begin{array}{l}\text { The same user separates a } \\
\text { comment into multiple } \\
\text { responses, consecutively. } \\
\text { For example: } \\
\text { Comment 1: It's an iPhone } \\
\text { 5? See screen } \\
\text { Comment 2: second } 52\end{array}$ & $\begin{array}{l}\text { Multiple comments that } \\
\text { occur consecutively will be } \\
\text { considered as one full } \\
\text { comment in the data set. }\end{array}$ \\
\hline $\begin{array}{l}\text { Multiple } \\
\text { Comments } \\
\text { (Nonconsecutive) }\end{array}$ & $\begin{array}{l}\text { The same users separate the } \\
\text { comment into multiple } \\
\text { responses; however, each } \\
\text { comment is separated by } \\
\text { other users' responses. }\end{array}$ & $\begin{array}{l}\text { Multiple comments that } \\
\text { occur non-consecutively } \\
\text { will be considered as two } \\
\text { separate comments in the } \\
\text { data set. }\end{array}$ \\
\hline $\begin{array}{l}\text { Multiple } \\
\text { Comments } \\
\text { (Nonconsecutive, } \\
\text { in response to other } \\
\text { users' comments) }\end{array}$ & $\begin{array}{l}\text { The comment is in } \\
\text { response to another user's } \\
\text { comment. }\end{array}$ & $\begin{array}{l}\text { Replies will not be } \\
\text { included in the data set } \\
\text { because the measurement is } \\
\text { reflective of a user's } \\
\text { reaction to other users' } \\
\text { comments and not to the } \\
\text { advertisement. }\end{array}$ \\
\hline
\end{tabular}


The structure for data collection is set within parameters of time and quantity. Data will be collected for the first 100 comments posted, and again for the last 100 comments available to date; this will be done for both Chrome ads, reaching a total number of 200 responses per advertisement for analysis. This approach considers that, if given an outcome with a high ratio of other comments to a low ratio of reactional and non-reactional responses, the quantity will be increased to provide a data set with a greater quality score. From the sample population of data collected, a manual scan will be taken to remove blank and duplicate comments, and to combine multiple responses from the same user. This process is to ensure that the data set yields a total of 100 comments from each allotted timeframe, per advertisement. Overall, the purpose of performing a comparative analysis is to gain insight as to how well or poorly the emotional marketing tactic is received, with the intention of determining its extent of effectiveness as a branding strategy.

Aforementioned, the second part of the research study follows a multimodal framework to understand the function and meaning of emotions as a marketing tactic. Here, the primary focus is to study Google's Dear Sophie (2011) advertisement. Drawing from Baldry and Thibault (2006) as well as Lim and O'Halloran (2012), this research paper takes both a macro- and micro-analytical approach to multimodal transcription to capture the semiotic modes represented in Dear Sophie; this allows the advertisement's basic message to be deconstructed. 
To do so, a codebook will be used for analysis, one that is designed with a format that mirrors the chronological sequence of frames and includes emotional marketing characteristics to group modes within each frame. The codebook used for transcription is presented in Appendix F. The criteria for frame extraction is based on transcribing the mini-narratives that, when taken together, tell Google's brand story.

The codebook will be used for two purposes. First, from a macroanalytical approach, the transcription will produce a video dissection of shots and macrophases for a summary analysis. This is adopted from Baldry and Thibault's (2006) method of a multimodal transcription through phasal analysis, which helps to pinpoint the basic strategic meaning-making units in a film text. With this, the information transcribed can be reconstructed to understand how each phase is integrated with written commentary, to flow together in time (Baldry, 2004; Baldry \& Thibault, 2006). This supports the research interests to develop an understanding of Google's brand story through the unfolding of the advertisement's narrative. Second, from a micro-analytical approach, the research extends to provide a detailed multimodal transcription and text analysis of the individual frames in Dear Sophie (2011). The codebook follows Baldry and Thibault's (2006) method of transcription, with an organized table to collect data by timestamp, visual frame, visual image, kinesic action, and soundtrack. To support the research interests of this MRP, a column titled, Meaning and 
Emotional Indicators, will be added for analysis, which also mirrors Baldry and Thibault's (2006) method of transcription from a selective perspective. With a specific focus on emotional appeal, the purpose is to investigate the, "complex multiplication of meanings made in a film text”' (Lim \& O'Halloran, 2012, p.230). The purpose of taking a multimodal approach is to study how emotional appeal is being achieved in the advertisement. This step provides a transcription to reveal the emotive representations within the advertisement's elements (modes) and written commentary, for a multimodal analysis of what patterns exist and what overall meaning this elicits. Based on the literature found on multimodality, this approach will present an organized data set to uncover emerging themes within Google's Dear Sophie (2011) advertisement.

\section{FINDINGS AND DISCUSSION}

The following sections present the research findings for analysis and discussion, to address the topic of the use of emotion in marketing, for brand storytelling. The discussion is led by findings from both the comparative analysis and multimodal transcription, and guided by current literature. The research questions associated with each area of study are addressed in the corresponding sections. The final section closes with considerations of the study's limitations and implications and from here, proposes new avenues for research. 


\subsection{Part I: Comparative Analysis Discussion of Results}

This discussion focuses on the first area of research, which aims to evaluate emotional marketing as an effective tactic for consumer-brand engagement. The intent of Part I is to address Research Questions 1 and 1(a). The research method for this study adopts the format and coding scheme from studies found in current literature. Particularly, the method echoes the research approach of Rytel (2010) and Yoo and MacInnis (2005) in evaluating response groupings based on consumer engagement, to study the relational and participatory features

of an ad format. Thus, the data collection method for this research paper considers response to be a measurable variable, as an indication of consumer-brand engagement relative to ad format. The objective of the analysis is to collect viewer response data from Google's advertisements promoting Chrome - Dear Sophie (2011) and Your Chrome, Everywhere (2012) - for a comparison of user reactions to an emotional ad format versus a functional ad format.

For the comparative analysis, 400 user-generated comments were extracted from YouTube, using a purposive sampling method. Each advertisement contributed 200 responses to the data set, collected from the first 100 and last 100 comments available to date. Note that, within these parameters, the date range was increased to provide codable data on account of removing blank and duplicate comments as well as the combination of multiple responses. For the 
purpose of measuring only user-generated responses, a single comment from account owner@GoogleChrome was removed from the data set. Record of all comments removed from or combined for the data set is referenced in Appendix A, with tables corresponding to each advertisement by allotted timeframe. Based on the initial results, the data collected yields a measurable quality score, given the low ratio of other comments posted in a foreign language, as non-related content or non-relevant spam. The final data set of 200 comments per video was imported to NVivo for manual user response sorting, by predefined primary categories (coding groups) and further into secondary groupings (subcategories). The coded results are summarized in Table 4.1, as per Figures B1 and B2 in Appendix B.

Table 4.1 provides a summary of the comments coded into NVivo. Primary coding groups are highlighted in grey and secondary coding groups are indicated in white. The results are calculated by percentage of response category per set of 200 responses, for each advertisement. Within each subcategory, percentages are calculated out of 200 comments, per advertisement. The table reads as, percentage by primary coding group, and again by secondary coding group. As follows, coding groups are calculated from 1, 2, and 3, whereas subcategories are calculated from 1A, 1B, 1C, 2, 3A, 3B, and 3C, each out of 200 responses per advertisement. 
Table 4.1: Comparative Analysis - Summary of Results

\begin{tabular}{l|l|l|l|l|}
\hline $\begin{array}{l}\text { Coding Groups and } \\
\text { Subcategories }\end{array}$ & Dear Sophie & $\%$ & $\begin{array}{l}\text { Your Chrome, } \\
\text { Everywhere }\end{array}$ \\
\hline 1. Reactional & 151 & 75.5 & 97 & 48.5 \\
\hline 1A. Reactional - Positive & 73 & 36.5 & 52 & 26 \\
\hline 1B. Reactional - Negative & 60 & 30 & 15 & 7.5 \\
\hline 1C. Reactional - Neutral & 18 & 9 & 30 & 15 \\
\hline 2. Non-Reactional & 23 & 11.5 & 54 & 27 \\
\hline 2. Non-Reactional & 23 & 11.5 & 54 & 27 \\
\hline 3. Other & 26 & 13 & 49 & 24.5 \\
\hline 3A. Foreign Languages & 5 & 2.5 & 7 & 3.5 \\
\hline 3B. Non-Related Content & 14 & 7 & 36 & 18 \\
\hline 3C. Non-Legible Spam & 7 & 3.5 & 6 & 3 \\
\hline
\end{tabular}

Additional metrics for comparison between Dear Sophie and Your

Chrome, Everywhere are provided in Table 4.2, as per the screenshots shown in Figures $\mathrm{C} 1$ and $\mathrm{C} 2$ in Appendix $\mathrm{C}$. The purpose of reviewing vanity metrics number of views, likes, dislikes, and comments - is to provide further rationale for the discussion of results and the interpretation of findings. To this point, the figures provide methodological considerations of the sampling strategy, such as, of the sampling ratio. The information also offers insight into how well each advertisement is performing, given the difference in ad format for promotion of 
the same product and services; thus, the comparison informs the research paper of the consumer-to-brand engagement.

Table 4.2: Comparative Analysis - Vanity Metrics

\begin{tabular}{|l|l|l|l|l|}
\hline Metrics & \multicolumn{2}{|l|}{ Dear Sophie } & \multicolumn{2}{l|}{ Your Chrome, Everywhere } \\
\hline Channel & \multicolumn{2}{|l|}{ Google Chrome } & \multicolumn{2}{l|}{ Google Chrome } \\
\hline Publish Date & \multicolumn{2}{|l|}{ May 2, 2011 } & \multicolumn{2}{|l|}{ June 28, 2012 } \\
\hline Views & $10,820,915$ & 374,091 \\
\hline & \% per total number of views & \% per total number of views \\
\hline Likes & 30,000 & 0.277 & 2,598 & 0.694 \\
\hline Dislikes & 2,889 & 0.027 & 97 & 0.026 \\
\hline Comments & 3,806 & 0.035 & 286 & 0.076 \\
\hline
\end{tabular}

* The information provided in the table indicates numerical values as of May 5, 2017

\subsection{Part I: Comparative Analysis Interpretation of Findings}

Many studies in consumer marketing interpret advertising according to behavioural appeal, by an ad's use of emotion or reason (Akbari, 2015; AlbersMiller \& Stafford, 1999; Chaudhuri, 2006; O'Shaughnessy \& O'Shaughnessy, 2003; Robinette et al., 2001; Rytel, 2010; Soscia, 2013; Thompson et al., 2006; Yoo \& MacInnis, 2005). The purpose of a comparative analysis is to evaluate the argument that, "emotional positioning is inherently superior to positioning your brand only on rational attributes" (Chaudhuri, 2006, p.29). As follows, the first 
area of research aims to understand why emotional marketing is considered an effective tactic for driving consumer-brand engagement.

In marketing literature, brand attitude and consumer purchase decisions are major targets of effective advertising (Gobé, 2009; O'Shaughnessy \& O'Shaughnessy; Soscia, 2013). Based on the theoretical intention behind an ad's execution format, emotional appeal is the primary focus for this research paper. The emphasis here derives from scholarly definitions of persuasive advertising, in differentiating rational appeal by intent to sell a product, from emotional appeal by intent to sell a brand. In this perspective, Robinette et al. suggest that, "emotion marketing impels people to act on [feelings] and gives them a reason to go beyond a single purchase to long-term loyalty" (2001, p.8). As discussed in the literature review, the focus of effective advertising is moving from rational to emotional stimuli to drive branding decisions (Gobé, 2009; Papadatos, 2006; Rytel, 2010). For this reason, emotional motive is the focus of Research Question 1, and the comparison to rational motive follows, with Research Question 1(a). Research Question 1 asks, "what is the nature of response to Google's emotional marketing strategy from the YouTube advertisement, Dear Sophie (2011), posted on the brand's Google Chrome account"? From an initial observation, the data collection indicates that emotional marketing produces high engagement between consumer to brand, and specific to the positive emotional appeal of Dear Sophie, the majority of reactions identify as being positive in 
return. In particular, the Dear Sophie response set shows that user-generated comments yield highest as reactional $(75.5 \%)$ and lowest as non-reactional (11.5\%). This means, of the 200 comments collected, 151 responses are emotional in nature and suggest engagement towards the advertisement or the brand. From here, 23 responses categorized as informational in nature and make a functional reference to the product itself. The remainder of responses coded as other $(26 \%)$, given that, of these comments, 5 are in foreign languages, 14 are non-related content, and 7 read as non-legible spam. The full summary of comments collected from Dear Sophie (2011) is provided in Appendix D.

Based on current literature, this research study considers the theoretical intent of an emotional appeal, that, "when the commercial uses an emotional format, brand attitudes are apparently driven through feeling responses" (Yoo \& MacInnis, 2005, p.1404). Taking into account, the ratio of reactional to nonreactional comments, the nature of response to the use of emotions in Google's Dear Sophie (2011) advertisement is favourably reactional; it influences a response that conveys feeling. This finding indicates that an emotionally motivated advertisement can drive consumer-brand connection. With this, Yoo and MacInnis confirm that both positive and negative feelings make an advertisement more appealing, "because those feelings positively influence ad attitudes through the mediational effect of evaluative thoughts" (2005, p.1404). This concludes Research Question 1. 
Next, Research Question 1a asks, "given the difference in ad format, what consumer-brand connections are evident in Google's Dear Sophie (2011) advertisement in comparison to Google's Your Chrome, Everywhere (2012) advertisement"? There are several areas of research to consider for discussion, taking into account the primary coding groups, secondary subcategories, and vanity metrics. From a micro perspective, the primary response sets from Dear Sophie and Your Chrome, Everywhere suggest that emotional appeal positively influences consumer-to-brand engagement. Following the coding criteria for data collection, comments that imply engagement towards the advertisement or brand, rather than to the product itself categorized as reactional; therefore, responses of this nature inform Research Question 1a of the impact an ad execution format has on consumer-to-brand engagement. With reference to the Comparative Analysis Summary of Results presented in Table 4.1, the findings indicate that reactional responses appear highest from Dear Sophie, and these results significantly outweigh the additional coding groups of both advertisements. Specifically, the extent of reactional responses yielded as $75.5 \%$ to Dear Sophie in comparison to 48.5\% to Your Chrome, Everywhere. Thus, the results from Part I of this study support the rationale discussed in Research Question 1, that an emotional ad format generates increased engagement from consumer to brand in comparison to an informational ad format. 
To further address Research Questions 1 and 1a, Table 4.3 and Table 4.4 provide a sample of the data collection from each advertisement. The tables are representative of the response characteristics associated with this study's emotionally formatted ad in comparison to the rationally formatted ad. The comments are selected at random, taking Reference 5 from each coding group of the data set. The sample excludes comments from the category of other, due to the scope of the research question as measuring the nature of response.

\section{Table 4.3: Dear Sophie (2011) Sample Data Collection}

\begin{tabular}{|c|c|}
\hline Data Set & Comment \\
\hline $\begin{array}{l}\text { Newest } 100 \text { - } \\
\text { 1.Reactional/1A.Positive Responses }\end{array}$ & This is beautiful! $<3$ \\
\hline $\begin{array}{l}\text { Oldest } 100- \\
\text { 2.Reactional/1A.Positive Responses }\end{array}$ & ooouuunm :') \\
\hline $\begin{array}{l}\text { Newest } 100- \\
\text { 1.Reactional/1B.Negative Responses }\end{array}$ & tears rolled down my eyes \\
\hline $\begin{array}{l}\text { Oldest } 100- \\
\text { 1.Reactional/1B.Negative Responses }\end{array}$ & $\begin{array}{l}\text { Marketing consultants take note - make } \\
\text { people fecking cry! }\end{array}$ \\
\hline $\begin{array}{l}\text { Newest } 100- \\
\text { 1.Reactional/1C.Neutral Responses }\end{array}$ & What does he say at $0: 18 ?$ \\
\hline $\begin{array}{l}\text { Oldest } 100- \\
\text { 1.Reactional/1B.Neutral Responses }\end{array}$ & $\begin{array}{l}@ \text { Robstailey his daughter... did you not } \\
\text { watch it? }\end{array}$ \\
\hline Newest $100-2$. Non-Reactional & I need help on how to email photos \\
\hline Oldest $100-2$. Non-Reactional & $\begin{array}{l}\text { This is awssm...can user create their } \\
\text { own chrome experiences ...?? }\end{array}$ \\
\hline
\end{tabular}


Table 4.4: Your Chrome, Everywhere (2012) Sample Data Collection

\begin{tabular}{|c|c|}
\hline Data Set & Comment \\
\hline $\begin{array}{l}\text { Newest } 100 \text { - } \\
\text { 1.Reactional/1A.Positive Responses }\end{array}$ & I'm so trying that beatbox \\
\hline $\begin{array}{l}\text { Oldest } 100 \text { - } \\
\text { 2.Reactional/1A.Positive Responses }\end{array}$ & Bravo, google is simply the best \\
\hline $\begin{array}{l}\text { Newest } 100- \\
\text { 1.Reactional/1B.Negative Responses }\end{array}$ & $\begin{array}{l}\text { I see this commercial EVERYWHERE } \\
\text { and it annoys the living heck out of } \\
\text { me... PLEASE LET IT STOP!!!!!! }\end{array}$ \\
\hline \multirow[t]{2}{*}{$\begin{array}{l}\text { Oldest } 100- \\
\text { 1.Reactional/1B.Negative Responses }\end{array}$} & $\begin{array}{l}\text { As much as I believe that everyone } \\
\text { should be able to experience chrome for } \\
\text { mobile, I'm a little bitter that google has } \\
\text { decided to put it on iOS. Chrome isn't } \\
\text { one of the reasons I'm on android, but } \\
\text { it's a nice distinguishing GOOGLE } \\
\text { feature. }\end{array}$ \\
\hline & $\begin{array}{l}\text { It's like google doesn't want Android to } \\
\text { succeed. }\end{array}$ \\
\hline \multirow[t]{2}{*}{$\begin{array}{l}\text { Newest } 100- \\
\text { 1.Reactional/1C.Neutral Responses }\end{array}$} & $\begin{array}{l}\text { because when he says "and now even } \\
\text { here" hes referring to the fact that } \\
\text { chrome is now available on iOS because } \\
\text { it hasn't always been where as it was on } \\
\text { android since release. }\end{array}$ \\
\hline & $\begin{array}{l}\text { I don't need saving by a pretend dead } \\
\text { man in a dress thanks. }\end{array}$ \\
\hline $\begin{array}{l}\text { Oldest } 100- \\
\text { 1.Reactional/1B.Neutral Responses }\end{array}$ & $\begin{array}{l}\text { WHAT IS THE SONG!!! ALSO } \\
\text { ANDROID FTW }\end{array}$ \\
\hline Newest $100-2$. Non-Reactional & can't open technitone on Iphone??? \\
\hline Oldest $100-2$. Non-Reactional & $\begin{array}{l}\text { so where can i get this in the market for } \\
\text { android? }\end{array}$ \\
\hline
\end{tabular}


In review of Table 4.3, the response to Dear Sophie indicates that a majority of the sample comments convey emotional engagement to the brand or advertisement, from both reactional and non-reactional categories. To exemplify, from the data set, "Oldest $100-2$. Non-Reactional", the comment reads, "This is awssm...can user create their own chrome experiences ... ??"; this can be interpreted from two perspectives. First, "This is awssm" expresses a positive reactional response towards the advertisement. Second, "can user create their own chrome experiences" indicates a non-reactional response and represents a functional question. For the purpose of this study, the comment was processed as non-reactional; however, it is important to note the emotional aspect attached to the functional response. This leads to the understanding that, the advertisement's execution format as emotional affects the consumer to engage with a response, which elicits a feeling towards the brand. Similarly, from a rational execution format, the response to Your Chrome, Everywhere as per Table 4.4, reveals shared expressions of informational engagement towards the product and services of Google Chrome. For example, from the data set, "Oldest 100 - 1.Reactional/ 1B.Negative Responses", the comment reads, "As much as I believe that everyone should be able to experience chrome for mobile, I'm a little bitter that google has decided to put it on iOS. Chrome isn't one of the reasons I'm on android, but it's a nice distinguishing GOOGLE feature. It's like google doesn't want Android to succeed." The comment communicates concern (eliciting surprise, anger and fear) 
for the brand's success and thus, is categorized as a reactional response. However, while the response appears reactional in nature, it remains targeted towards the functional aspect that is advertised of the product. Beyond the research scope this is an interesting observation, considering that the intent of using an informational ad format is to persuade consumers' purchase decisions (Chaudhuri, 2006; O'Shaughnessy \& O'Shaughnessy, 2003). More specific to this study, Yoo and MacInnis (2005) note that the purpose of an informational ad execution is to address an audience's evaluative thoughts towards the ad's credibility, which in turn, may affect consumers' feeling responses. The data collected for Dear Sophie is provided in Appendix D, which is summarized by coding group in Tables D1, D2, D3, D4, D5, D6, and D7. The data collected for Your Chrome, Everywhere is provided in Appendix E, and further summarized by coding group in Tables E1, E2, E3, E4, E5, E6, and E7.

Altogether, the sample data from Tables 4.3 and 4.4 suggest that audience engagement is influenced by ad execution format. The nature of response to Dear Sophie is feelings-oriented with consumer-to-brand interaction qualities; whereas, to Your Chrome, Everywhere, the response is knowledge-oriented with a consumer-to-product relationship. This reasoning is discussed in marketing literature, whereby behavioural response is determined by the emotional or rational value that a consumer attaches to an advertisement, whether that be 
towards a brand or a product and service (Akbari, 2015; Chaudhuri, 2006; Matthes, Wonneberger \& Schmuck, 2013; 2014; Yoo \& MacInnis, 2005).

While the focus of this study is to evaluate the extent that consumer-tobrand engagement is relative to ad format, it is valuable to understand the research context from a macro perspective. The Comparative Analysis - Vanity Metrics provided in Table 4.2 informs this study of the sampling ratio from which the data was collected and serves as a performance indicator. Vanity metrics are useful analytics to measure the value of the data collected, by showing if and how active a user is. Accordingly, engagement simply implies traffic, whereas, interaction is specified by a click or comment that requires the user to take action beyond a site visit. Specific to this study, vanity metrics indicate the extent that consumer interaction occurs as an active form of engagement towards the brand and therefore, is considered actionable data.

The statistics from Table 4.2 are displayed in percentages, which is calculated by number of likes, dislikes, and comments per total number of views on YouTube. By comparison, the sampling ratio differed considerably with a sample size of 200 comments per advertisement. Dear Sophie reached a total population of $10,820,915$ views, yielding a $0.0018 \%$ sampling ratio, whereas, Your Chrome, Everywhere amounted to a population of 374,091 views, generating a $0.053 \%$ sampling ratio. On account of performance, Dear Sophie surpassed Your Chrome, Everywhere in total number of views, gaining 
$10,820,915$ impressions to the emotional ad format in comparison to 374,091 impressions to the rational ad format. In addition to number of views, the emotional ad format exceeded the rational ad format with 30,000 likes to 2,598 likes. Based on traffic in views and interaction in terms of positive clicks, the data initially suggests that ad execution format by emotion generates greater consumer-brand engagement relative to ad execution format by reason. However, in evaluating the amount of actionable data - likes, dislikes, and comments - per total number of views, the findings reveal that the audience is more interactive with the brand when the ad execution format is functional. Your Chrome, Everywhere generated higher interaction (active engagement) than Dear Sophie, in terms of likes, dislikes, and comments relative to advertisement views. In particular, the functional ad format gained $0.694 \%$ in likes and $0.076 \%$ in comments, compared to $0.277 \%$ in likes and $0.035 \%$ in comments towards the emotional ad format. These findings are further supported by the metrics indicated of negative engagement, showing that Your Chrome, Everywhere received fewer dislikes than Dear Sophie. Altogether, the vanity metrics suggest that ad execution by emotion is effective for consumer engagement with the brand; however, ad execution by reason appears to be more valuable in terms of actionable results for consumer to brand interaction. This concludes Research Questions 1a. 


\subsection{Part II: Multimodal Analysis Discussion of Results}

This discussion focuses on the second area of research, which aims to study how emotion is used to market for the purpose of brand loyalty. The intent of Part II is to address Research Question 2, as the discussion corresponds with Part I of this study. This component of the study primarily focuses on Google's Dear Sophie (2011) advertisement for its emotional ad format, and uses multimodal transcription for analysis.

The advertisement tells the story of a father who creates a digital scrapbook to chronicle his daughter's childhood using Google Chrome in collaboration with Google's applications. The frame-based transcription of Dear Sophie (2011) is prepared in such a way as to show how the story creates meaning through a series of functional units. Each video still captures the emotions used to advertise Google Chrome and informs this study of how the brand is marketed, as each scene of the story unfolds. The micro-analytical approach is adopted from Baldry and Thibault's (2006) multimodal method of analysis, with a few additions and modifications. The advertisement is organized in six phases that group together 57 individual shots, which collectively, tell Google's brand story. The full transcription of Dear Sophie is provided in Appendix G. Table 4.5 is a summary analysis of the advertisement's shots and phases. 
Table 4.5: Dear Sophie (2011) - Summary Analysis of Shots and Phases

\begin{tabular}{|c|c|c|}
\hline Shots & Phases & Description of Phases \\
\hline Shots $1-2$ & $\begin{array}{l}\text { Phase 1: } \\
\text { Introduction }\end{array}$ & Google Chrome logo appears on screen \\
\hline Shots 3-19 & $\begin{array}{l}\text { Phase 2: } \\
\text { Story Begins } \\
\text { (context) }\end{array}$ & $\begin{array}{l}\text { The dear.sophie.lee@gmail.com account is } \\
\text { created, and the story begins with an email } \\
\text { message, "Dear Sophie, You arrived!"; } \\
\text { from here, the scenes move to Sophie's first } \\
\text { birthday, a train ride, and the moment she } \\
\text { becomes a big sister }\end{array}$ \\
\hline Shots $20-23$ & Phase 3: Conflict & $\begin{array}{l}\text { The subject line reveals that Sophie is in the } \\
\text { hospital; the message reads, "We felt so } \\
\text { helpless"; the scene concludes with Sophie } \\
\text { smiling in the hospital bed indicating her } \\
\text { recovery }\end{array}$ \\
\hline Shots $24-45$ & $\begin{array}{l}\text { Phase 4: } \\
\text { Climax }\end{array}$ & $\begin{array}{l}\text { The scenes move from a video of Sophie's } \\
4^{\text {th }} \text { birthday, a map of her first home, } \\
\text { Father's Day, and an online photo album of } \\
\text { father-daughter moments (underwater, } \\
\text { snowboarding, the tooth fairy, learning to } \\
\text { ride a bike, and ballet lessons); the } \\
\text { functions of Chrome and Google } \\
\text { applications are revealed }\end{array}$ \\
\hline Shots $46-52$ & $\begin{array}{l}\text { Phase 5: } \\
\text { Closure }\end{array}$ & $\begin{array}{l}\text { The story comes to a close, indicated by a } \\
\text { final email that reads, "I've been writing } \\
\text { you since you were born. I can't wait to } \\
\text { share these with you someday. Until then... } \\
\text { Love, Dad" }\end{array}$ \\
\hline Shots $53-57$ & $\begin{array}{l}\text { Phase 6: } \\
\text { Conclusion }\end{array}$ & $\begin{array}{l}\text { The campaign title, The web is what you } \\
\text { make of it, appears; Google Chrome and its } \\
\text { extension icons appear; the advertisement } \\
\text { concludes with the Google Chrome icon } \\
\text { and website link }\end{array}$ \\
\hline
\end{tabular}


From a macro perspective, it appears that the story of Dear Sophie is told using a typical literary structure, which allows the audience to follow along as the narrative unfolds. Throughout the advertisement, there is a distinct outline of where one phase transitions to another and this is distinguished in the transcription; the story has a beginning, middle (climax), and end. More specifically, Phase 1 groups together the advertisement's opening; it introduces the brand as well as the product being advertised through a logo placement of Google Chrome. Moving into Phase 2, each frame establishes the advertisement's context and tone, and develops the plot. From shots 3 to 19, the audience is familiarized with the advertisement's emotional appeal, whereby a father uses Google's applications to create, capture, and share many of his daughter's milestones, to her future self. Close-up shots of the email account, dear.sophie.lee@gmail.com, indicates how the advertisement transitions from one scene to the next through text, picture, and video attachments. Next, Phase 3 alters the emotional tone from positive to negative by bringing conflict to the sentimental storyline. A combination of suspense and sadness are conveyed solely through the use of text, rather than picture. There is no connection from viewer to participant to gauge facial expression or gesture Moving to Phase 4, the advertisement is repositioned as positive where the story reaches its climax. From shots 24 to 45 , the advertisement connects emotion with reason by revealing the functional aspects of what Google, as a brand, can offer to the consumer. The 
story prepares to close in Phase 5 with a nostalgic final email. Lastly, Phase 6 presents the campaign, brand, and product logo to conclude the advertisement. The full analysis of Dear Sophie is discussed in the following section.

\subsection{Part II: Multimodal Analysis Analysis of Findings}

Studies on emotional marketing suggest that feelings can be used to predict brand attitudes (Bagozzi et al., 1999; Chaudhuri, 2006; Dobele et al., 2007; Fox, 2008; Matthes et al., 2013; 2014; Soscia, 2013; Yoo \& MacInnis, 2005). As discussed in Part I, there is a strong relationship between ad execution format and consumer-brand engagement as well as brand attitude; it is likely that positive evaluative thoughts towards an advertisement will influence positive engagement in return (Yoo \& MacInnis, 2005). Continuing from Part I of this study, Research Question 2 asks, "how is emotional marketing used in Google's Dear Sophie (2011) advertisement, to tap into feelings that encourage viewers to use Chrome"? As follows, this section will first discuss the use of emotions in Google's Dear Sophie (2011) advertisement based on the data collected for transcription and then, cross-reference the response sets from the comparative analysis. The aim is to address Research Question 2 by formulating conclusions around the patterns that exist between ad execution format and consumer to brand engagement. 
Appendix G presents the frame-by-frame transcription of Google's Dear Sophie (2011) advertisement. The transcription is arranged in a table format and organized by seven vertical columns: 1) Timestamp; 2) Visual Frame; 3) Visual Image; 4) Kinesic Action; 5) Soundtrack; 6) Emotive Expression; and 7) Meaning and Emotional Indicators. Column 1 specifies the time in seconds, at which each visual frame in Column 2 occur. The subsequent columns provide descriptive accounts of the individual semiotic resources that exist as the film text progresses. Column 3, headed Visual Image, relates to the previous column; it describes the pictorial details of the visual frame with which it corresponds. Column 4, headed Kinesic Action, indicates the use of on-screen movements (on Google's interface) and human action (by participants). Column 5, headed Soundtrack, refers to all relevant aspects of the soundtrack - music and tempo, ambient sounds, and voiceovers. Lastly, Columns 6 and 7 represent the use of emotions, from both pictorial and textual interpretations. Emotional appeal is referenced as positive (pleasant) or negative (unpleasant) in Column 6, and the emotion is specified in Column 7. Further, for each vertical column, a horizontal row is assigned for each of the 57 video stills, titled Shot. The shots are numbered in the leftmost vertical column for the purpose of cross-referencing any of the seven columns by the particular row with which it intersects. On the rightmost vertical column, the horizontal rows are grouped into six macrophases. The abbreviations used for the transcription are provided in the second row, as each corresponds with the vertical 
column directly above. Note that, the short form for Participants $(P 1=\mathrm{Dad} ; P 2=$ Sophie) is specified in the second row of Column 2, as the abbreviations are used across Columns 3, 4, and 5. The table can be read from left to right, as the transcription progresses chronologically from top to bottom.

The transcription of Dear Sophie (2011) represents a visual, auditory, and textual description of the original interactions and sound accompaniments, as each shot appears in the advertisement. The multimodal timeline layout, as outlined above, is intended for interpretation and analysis of the patterns that exist within and between modes. The table format is designed to address the question of how emotional marketing is used, by answering with what resources exist to produce a given (phase-specific) meaning (Baldry, 2004; Baldry \& Thibault, 2006). Because the focus of this analysis is to answer Research Question 2, the following discussion primarily evaluates the transcription from Columns 6 and 7, as the preceding columns relate.

To begin, the transcription informs this study of the interactions and relationships that contribute to the emotional appeal of the advertisement. These meaning-making semiotic resources are described in Columns 3, 4, and 5, and interpreted in Columns 6 and 7. The advertisement creates meaning in the relations between the participants, process and circumstances that are realized in the use of verbal and nonverbal cues. Specifically, Column 3 describes two types of nonverbal interactions, which occur between participant to participant and from 
participant to computer (Google). The latter relationship considers any on-screen text, such as, in the form of an email, to be a participant to computer interaction. Of the 57 video stills, 16 frames showed $P 1$ and $P 2,22$ displayed Google's applications, and 19 used text to develop the story. With this, Column 4 describes the type of interaction by gesture (participants), movement (computer), or as static (computer). Out of 57 shots, 14 indicated a gesture by $P 1$ or $P 2,40$ had on-screen movement (i.e. typing), and 3 appeared as a still text. Further, Column 5 indicates how the instrumental (nonverbal) soundtrack guides the story and reaffirms the emotions that are conveyed in each scene. In particular, Column 5 corresponds with Column 7, whereby as the tempo moves at a medium to fast pace the emotion is indicated as happiness; similarly, as the tempo slows, the emotion is felt as sadness. The purpose of acknowledging these variables is to understand how emotion is communicated through the interactions that take place, to progress the advertisement.

Based on current literature, the emotional appeal of Dear Sophie (2011) derives from participant interaction in relation to the circumstance of the given situation (scene). This is consistent with the notion that, "emotional branding is a means of creating a personal dialogue with consumers" (Gobé, 2009, p.xxvi). In this way, the type and frequency of exchange in each frame helps to explain how emotion is used in the advertisement. There are two considerations that define how the communication of emotion can be interpreted. First, emotion is often 
expressed physically by way of bodily movements, such as in gestures or facial features (Bagozzi et al., 1999). Second and in relation, basic emotions, such as happiness or sadness, are universally recognizable (Feng \& O’Halloran, 2012). Accordingly, Columns 6 and 7 of the transcription reveal that basic emotions are used in Dear Sophie (2011) to connect the consumer to the brand. In considering the variable with the greatest number of visual frames, Column 3 indicates that participant to computer interaction appeared in 41 frames. Accordingly, Column 6 reveals that 32 frames expressed positive emotion through text or image; and Column 7 specifies that 24 of the emotions expressed happiness. Further, Column 5 shows that 39 out of 57 shots played the soundtrack at a medium to fast tempo, indicating happiness or excitement. Aforementioned, the soundtrack places emphasis on the emotions that are visible in each frame. For the most part, the tempo moves at a medium to fast pace when the emotion is indicated as happiness, as per Column 7. Thus, in response to Research Question 2, Dear Sophie (2011) primarily uses emotions of happiness to advertise Google Chrome in the form of human to computer interactions, positive visual and textual expression, and positive auditory accompaniments. Table 4.6 is a summary analysis of the transcription specific to Columns $3,4,5,6$, and 7 . 
Table 4.6: Transcription of Dear Sophie (2011) - Summary Analysis

\begin{tabular}{|c|c|c|}
\hline Variable & \# of Shots & $\%$ per 57 shots \\
\hline \multicolumn{3}{|c|}{ Column 3: Visual Image } \\
\hline Human Interaction (P1 or P2) & 16 & 28.1 \\
\hline Computer Interaction (Google Interface) & 22 & 38.6 \\
\hline Text & 19 & 33.3 \\
\hline \multicolumn{3}{|c|}{ Column 4: Kinesic Action } \\
\hline Gesture (Human) & 14 & 24.6 \\
\hline Movement (Computer) & 40 & 70.2 \\
\hline$\varnothing$ & 3 & 5.2 \\
\hline \multicolumn{3}{|c|}{ Column 5: Soundtrack } \\
\hline Tempo: Slow & 18 & 31.6 \\
\hline Tempo: Medium or Fast & 39 & 68.4 \\
\hline \multicolumn{3}{|c|}{ Column 6: Emotive Expression } \\
\hline Positive (Pleasant) & 32 & 56.1 \\
\hline Negative (Unpleasant) & 4 & 7.1 \\
\hline Neutral & 21 & 36.8 \\
\hline \multicolumn{3}{|c|}{ Column 7: Meaning and Emotional Indicators } \\
\hline Positive (Happiness) & 24 & 42.1 \\
\hline Negative (Sadness, Nostalgia) & 16 & 28.1 \\
\hline Neutral & 17 & 29.8 \\
\hline
\end{tabular}


Finally, from cross-referencing the data collected for Part I and Part II of this research project, the results indicate there is a correlation between ad execution format and consumer-brand engagement. When positive emotion is used in an advertisement, consumer engagement is apparently positive in response. Drawing from Tables 4.6 and 4.1, the data collected for Dear Sophie (2011) reveals that $42.1 \%$ of the advertisement shows positive emotion (happiness), and similarly, $48.3 \%$ of the users responded with a positive comment. This means, specific to positive emotion as relating to positive response, the results from the multimodal analysis are aligned with that of the comparative analysis. The transcription shows that of the 57 shots captured, 24 indicate happiness in the visual frame. In the same way, the response set indicates that of the 151 reactional comments, 73 are positive. At this time, there is little indication that negative emotion (sadness, fear, anger, etc.) correlates with user engagement as being negative in response.

Overall, the results from Part I and Part II of this study indicate three major findings: 1) ad execution by emotion drives higher consumer-brand engagement, in comparison to ad execution by reason; 2) ad execution by reason appears to be more valuable for actionable consumer-brand interaction; and 3) there is indication that ad execution format by positive emotion influences a response of positive consumer-brand attitude. 


\section{CONCLUSION}

This research paper intended to study how emotional marketing influences brand storytelling, and develop an understanding as to why the strategy is considered effective for driving consumer-brand engagement. Section 1 introduced the research interests. Section 2 referenced current literature to clearly state the research questions. Next, Section 3 presented the research methods to carry out this study. From here, Section 4 provided an in-depth discussion of the results and interpretation of findings to answer the research questions. Finally, this section concludes the research paper in a discussion of the findings, and outlines the research limitations, followed by suggestions for further research beyond this study.

\subsection{Significance of Findings}

Current marketing and communications literature address brand storytelling in comparison to product advertising. This study places emphasis on the differentiation of the two strategies, by exploring branding through marketing with emotion and advertising through communicating with reason. Beyond the question of how and why emotional marketing is effective for consumer-brand engagement, the findings provide answers as to what this means in terms of interaction and attitude based on ad execution format. The significance of this study's findings is specific to the results of Google's marketing campaigns, Dear 
Sophie (2011) and Your Chrome, Everywhere (2012), which establishes valuable groundwork for further research. The results from both Part I and Part II of this study suggest there is opportunity to develop the findings to understand the use of emotion in marketing.

Considering the argument that, "emotional positioning is inherently superior to positioning your brand only on rational attributes" (Chaudhuri, 2006, p.29), this study supports the statement for the purpose of branding. Given the overall findings in consumer-brand engagement and user response in attitude, the strategy of marketing with emotion indicates greater brand positioning. However, if the advertising intention is to market the product, the findings indicate that rational positioning provides greater benefit in terms of consumer-brand interaction; that is, it causes active engagement. The value in these findings is the perspective that this study offers to communication researchers and industry professionals for the purpose of developing a marketing strategy. Although the findings are not indicative of specific marketing objectives, such as, to generate positive feelings towards a brand, there is value in having the ability to focus on an ad format that helps to achieve a particular type of attachment; that being, loyalty to the brand or purchasing of the product. The results encourage critical thinking as to what the overall goal is and how the strategy can support this based on ad execution format; this is especially relevant to a global marketing campaign, to determine what expected outcomes can be achieved reasonably. 
Further, this study brings emotional marketing and brand storytelling together from the perspective of O'Shaughnessy and O'Shaughnessy, in establishing that, "emotion is the adhesive that, when mixed with trust, equals loyalty" (2003, p.5). While the scope of research limits the extent of this study from confirming this statement, the findings are supportive of the studies discussed in the literature review. Given that the research resulted in a relatively high number of reactional responses for both the emotional and functional advertisements, there are several key points for discussion. First, the results correspond with current literature findings, that brand storytelling enables the consumer-brand relationship that emotional marketing helps to create (Granitz \& Forman, 2015; Lundqvist et al., 2013; Pera \& Viglia, 2016). This is indicated by the significant number of reactional responses primarily to the emotionally formatted ad. Second, there is reason to consider that, regardless of the ad format, emotional codes are becoming the dominant manner through which audiences are interpreting advertisements. Lastly and in direct relation to brand loyalty, there is the possibility that since Dear Sophie (2011) preceded Your Chrome, Everywhere (2012), the consumer-brand relationship carried on from the first advertisement to the next. This supports that fact that, emotional marketing is considered effective for driving consumer-brand engagement, which leads to brand loyalty. Additional research into this relationship can provide greater insight into how ad execution format influences consumer-brand engagement and overall brand attitude. 


\subsection{Limitations and Implications}

Part I of this study saw several challenges from the data collection process, leading to the comparative analysis. By comparison, the sampling strategy is considerably disproportionate in evaluating Dear Sophie (2011) and Your Chrome, Everywhere (2012); however, this may be an indication of how ad execution format differs in engagement. For this reason, the sample size remained at 200 comments per advertisement given the difference in total population, which is further reduced by multiple, duplicate and blank comments. The irregularity in comments impacted the data for several reasons, being that first, the user set is not diverse; second, the sample size is lowered; and lastly, the conversational response is changed in meaning as a singular comment. Future research should expand the sampling strategy, either by advertisement selection for comparison, or revise the coding criteria to include all irregular responses as is. Of additional concern with data processing, is the coding of user-generated comments. That is, the true meaning intended of a user-generated response remains unknown, and to this extent, coding is subjective to the researcher. A study designed in collaboration with linguists and psychologists on emotional meaning could provide valuable guidance for marketers.

In Part II of this study, the multimodal analysis is limited in scope and scale. Scholars of multimodality discuss a major challenge to transcription of a film text, that is, the amount of information that can be processed (Baldry, 2004; 
Baldry \& Thibault, 2006; Lim \& O’Halloran, 2012). The process of transcription is time consuming and labour intensive. Therefore, to fully execute a multimodal transcription and text analysis, the study requires access to software programs that have the capacity to capture all of the modes that are found in a film text. With these resources, a large number of dynamic texts can be transcribed accurately and efficiently for further analysis (Baldry, 2004).

Finally, due to the scope of this study, the research was limited by time as well as resources. That is, this study focuses on ad format effectiveness primarily from appeal by emotion, rather than reason. Future research could continue this study by expanding the multimodal transcription to include Your Chrome, Everywhere in addition to studying Dear Sophie. With this, the researcher could carry out an extensive comparative analysis that cross-references response sets to both transcriptions. This would contribute to this study's conclusion on the relationship between ad execution format and brand attitude. To take this further, future research could quantify the results of this study with data for how many individuals used Chrome post advertisement release date. Again, a crosscomparison with the numbers presented in this research project could suggest the extent of effectiveness of an emotional ad execution format versus an informational ad execution format. This information would be valuable to marketers, in developing an engaging and profitable marketing strategy. 


\subsection{Concluding Remarks}

Studies on emotional marketing have had limited attention by researchers. However, this study expands the literature available to marketers, advertisers, and communication professionals. This research paper discussed three major findings: 1) ad execution by emotion drives higher consumer-brand engagement, in comparison to ad execution by reason; 2) ad execution by reason appears to be more valuable for actionable consumer-brand interaction; and 3) there is indication that ad execution format by positive emotion influences a response of positive consumer-brand attitude. To conclude, the research carried out in this study in addition to the issues outlined above, suggest there is opportunity to expand this understanding for the role that emotions have in marketing. 


\section{Reference List}

Akbari, M. (2015). Different impacts of advertising appeals on advertising attitude for high and low involvement products. Global Business Review, 16(3), 478-493. doi:10.1177/0972150915569936

Akgün, A. E., Koçoğlu, İ., \& İmamoğlu, S. Z. (2013). An emerging consumer experience: Emotional branding. Procedia - Social and Behavioral Sciences, 99, 503-508. doi:10.1016/j.sbsro.2013.10.519

Albers-Miller, N. D., \& Royne Stafford, M. (1999). An international analysis of emotional and rational appeals in services vs goods advertising. Journal of Consumer Marketing, 16(1), 42-57. doi:10.1108/07363769910250769

Bagozzi, R. P., Gopinath, M., \& Nyer, P. U. (1999). The role of emotions in marketing. Journal of the Academy of Marketing Science, 27(2), 184-206. doi:10.1177/0092070399272005

Balgaradean, C. (2015). Emotions and marketing: A theoretical approach. The Proceedings of the International Conference "Marketing - from Information to Decision", 8-22.

Retrieved from http://ezproxy.lib.ryerson.ca/login?url=http://search.proquest.com /docview/1751219522?accountid=13631

Baldry, A., \& Thibault, P.J. (2006). Multimodal transcription and text analysis: A multimedia toolkit and coursebook. Equinox Publishing.

Baldry, A. (2004). Phase and transition, type and instance: patterns in media text as seen through a multimodal concordancer. In K.L. O’Halloran (Ed.), Multimodal discourse analysis: Systemic-functional perspectives (pp. 83-108). New York, NY: Continuum.

Bartle Bogle Hegarty (2015). Google chrome: the web is what you make of it. Retrieved from http://www.bartleboglehegarty.com/newyork/work/the-web-is-what-you-make-of-it/ 
Bezemer, J., \& Mavers, D. (2011). Multimodal transcription as academic practice: A social semiotic perspective. International Journal of Social Research Methodology, 14(3), 191-206. doi:10.1080/13645579.2011.563616

Bou Franch, P. (2012). Multimodal discourse strategies of factuality and subjectivity in educational digital storytelling. Digital Education Review, (22), 80-91.

Chaudhuri, A. (2006). Emotion and reason in consumer behavior. Burlington, MA: Elsevier Butterworth-Heinemann.

Dash, A. K., Patnaik, P., \& Suar, D. (2016). A multimodal discourse analysis of glocalization and cultural identity in three indian TV commercials. Discourse \& Communication, 10(3), 209-234. doi:10.1177/1750481315623892

Del Saz-Rubio, M., \& Pennock-Speck, B. (2009). Constructing female identities through feminine hygiene TV commercials. Journal of Pragmatics, 41(12), 2535=2556/ doi:10.1016/j.pragma.2009.04.005

Dobele, A., Lindgreen, A., Beverland, M., Vanhamme, J., \& van Wijk, R. (2007). Why pass on viral messages? Because they connect emotionally. Business Horizons, 50(4), 291-304. doi:10.1016/j.bushor.2007.01.004

Fox, E. (2008). Emotion science: Cognitive and neuroscientific approaches to understanding human emotions. London, United Kingdom: Palgrave Macmillan.

Gobé, M. (2009). Emotional branding: The new paradigm for connecting brands to people. New York: Allworth Press.

Google. (2008, September 2). Google chrome: A new take on the browser [Press release]. Retrieved from http://googlepress.blogspot.ca/2008/09/google-chrome-new-take-onbrowser_02.html 
Google Chrome. (2012, June 28). Your chrome, everywhere [Video file]. Retrieved from https://www.youtube.com/watch?v=tSKZy2ayvMs

Google Chrome. (2011, May 2). Google chrome: Dear Sophie [Video file]. Retrieved from https://www.youtube.com/watch?v=R4vkVHijdQk

Granitz, N., \& Forman, H. (2015). Building self-brand connections: Exploring brand stories through a transmedia perspective. Journal of Brand Management, 22(1), 38-59. doi: $10.1057 / \mathrm{bm} .2015 .1$

Grisaffe, D. B., \& Nguyen, H. P. (2011;2010;). Antecedents of emotional attachment to brands. Journal of Business Research, 64(10), 1052-1059. doi:10.1016/j.jbusres.2010.11.002

Herskovitz, S., \& Crystal, M. (2010). The essential brand persona: Storytelling and branding. Journal of Business Strategy, 31(3), 21-28. doi:10.1108/02756661011036673

Honeyford, M. A. (2013). The simultaneity of experience: Cultural identity, magical realism and the artefactual in digital storytelling. Literacy, 47(1), 17-25. doi:10.1111/j.17414369.2012.00675.x

Huang, M. (2001). The theory of emotions in marketing. Journal of Business and Psychology, 16(2), 239-247. doi:10.1023/A:1011109200392

Jack, R. E., Garrod, O. G. B., \& Schyns, P. G. (2014). Dynamic facial expressions of emotion transmit an evolving hierarchy of signals over time. Current Biology, 24(2), 187-192. doi:10.1016/j.cub.2013.11.064

Jewitt, C. (2009). An introduction to multimodality. In The routledge handbook of multimodal analysis. (pp. 14-27). New York: Routledge.

Lim, V., \& O'Halloran, K. L. (2012). The ideal teacher: An analysis of a teacher-recruitment advertisement. Semiotica, 2012(189), 229-253. doi:10.1515/sem-2012-0032 
Lundqvist, A., Liljander, V., Gummerus, J., \& Riel, A. (2013). The impact of storytelling on the consumer brand experience: The case of a firm-originated story. The Journal of Brand Management, 20(4), 283-297. doi:10.1057/bm.2012.15

Machin, D., Ph. D. (2007). Introduction to multimodal analysis. New York: Hodder Arnold.

Matthes, J., Wonneberger, A., \& Schmuck, D. (2013;2014;). Consumers' green involvement and the persusasive effects of emotional versus functional ads. Journal of Business Research, 67(9), 1885. doi:10.1016/j.busres.2013.11.054

O'Halloran, K. L. (2008). Systemic functional-multimodal discourse analysis (SF-MDA): Constructing ideational meaning using language and visual imagery. Visual Communication, 7(4), 443-475. doi:10.1177/1470357208096210

O’Halloran, K. L. (2004). Multimodal discourse analysis: Systemic functional perspectives. New York, NY: Continuum.

O'Shaughnessy, J., \& O'Shaughnessy, N. J. (2003). The marketing power of emotion. New York: Oxford University Press.

Papadatos, C. (2006). The art of storytelling: How loyalty marketers can build emotional connections to their brands. Journal of Consumer Marketing, 23(7), 382-384. doi:10.1108/07363760610712902

Pera, R., \& Viglia, G. (2016). Exploring how video digital storytelling builds relationship experiences. Psychology \& Marketing, 33(12), 1142-1150. doi:10.1002/mar.20951

Robinette, S. Brand., C., \& Lenz, V. (2001). Emotion marketing: The hallmark way of winning customers for life. New York, NY: McGraw-Hill.

Rytel, T. (2010). Emotional marketing concept: The new marketing shift in the postmodern era. Business: Theory and Practice, 11(1), 30-38. Retrieved from 
http://go.galegroup.com.ezproxy.lib.ryerson.ca/ps/i.do? $\mathrm{p}=\mathrm{AONE \& sw}=\mathrm{w} \& \mathrm{u}=\mathrm{rpu}$ main\& $\mathrm{v}=2.1 \& \mathrm{it}=\mathrm{r} \& \mathrm{id}=\mathrm{GALE} \% 7 \mathrm{CA} 227364021 \& \mathrm{sid}=$ summon\&asid $=693351223 \mathrm{a} 501 \mathrm{e} 8 \mathrm{fd} 8 \mathrm{e} 00$ $5 \mathrm{~b} 551 \mathrm{fld} 373$

Soscia, I. (2013). Emotions and consumption behaviour. United Kingdom: Edward Elgar Publishing Limited.

Thompson, C. J., Rindfleisch, A., \& Arsel, Z. (2006). Emotional branding and the strategic value of the doppelgänger brand image. Journal of Marketing, 70(1), 50-64.

doi:10.1509/jmkg.2006.70.1.50

Wang, J. (2016). Multimodal narratives in SIA's "singapore girl" TV advertisements - from branding with femininity to branding with provenance and authenticity? Social Semiotics, 26(2), 208-225. doi:10.1080/10350330.2015.1092277

Yoo, C., \& MacInnis, D. (2005). The brand attitude formation process of emotional and informational ads. Journal of Business Research, 58(10), 1397-1406.

doi:10.1016/j.jbusres.2005.03.011 


\section{Appendix A: Part I: Comparative Analysis Data Set Evaluation}

The following Tables A1, A2, A3, and A4 in Appendix A provide record of the blank, duplicate, and multiple user responses found in the data collected with the YouTube Comment Scraper. The report is organized by data set of each advertisement's first 100 comments (newest 100) and last 100 comments (oldest 100), collected as of May 5, 2017.

Table A1: Dear Sophie (2011) - Newest 100 report for blank, duplicate, and multiple responses.

\begin{tabular}{|c|c|c|c|}
\hline \multicolumn{4}{|c|}{ Dear Sophie - Newest 100} \\
\hline Criteria & User & Comment & Research Notes \\
\hline $\begin{array}{l}\text { Blank } \\
\text { Comments }\end{array}$ & $\begin{array}{l}\text { Youssef Ait } \\
\text { Man }\end{array}$ & No comment & Removed from data set \\
\hline $\begin{array}{l}\text { Duplicate } \\
\text { Comments }\end{array}$ & aaron green & $\begin{array}{l}\text { Comment 1: This is gay af } \\
\text { Comment 2: this is gay af }\end{array}$ & $\begin{array}{l}\text { Comment } 2 \text { removed } \\
\text { from the data set }\end{array}$ \\
\hline \multirow[t]{2}{*}{$\begin{array}{l}\text { Multiple } \\
\text { Comments } \\
\text { (Consecutive) }\end{array}$} & Maskindelar & $\begin{array}{l}\text { Comment 1: So nice } \\
\text { Comment 2: I'm from } 2017 \\
\text { but good luck everyone } \\
\text { Comment 3: Happy Father's } \\
\text { Day your good people who } \\
\text { watched this vid }\end{array}$ & $\begin{array}{l}\text { Combined as one } \\
\text { comment in the data set }\end{array}$ \\
\hline & $\begin{array}{l}\text { Sherry } \\
\text { Patterson }\end{array}$ & $\begin{array}{l}\text { Comment 1: This is me sherry } \\
\text { Patterson } \\
\text { Comment 2: can someone } \\
\text { help me get back on Facebook } \\
\text { plz }\end{array}$ & $\begin{array}{l}\text { Combined as one } \\
\text { comment in the data set }\end{array}$ \\
\hline \multicolumn{4}{|l|}{$\begin{array}{l}\text { Multiple } \\
\text { Comments } \\
\text { (Nonconsecutive) } \\
\end{array}$} \\
\hline \multicolumn{4}{|l|}{$\begin{array}{l}\text { Multiple } \\
\text { Comments } \\
\text { (Nonconsecutive, } \\
\text { in response to } \\
\text { other users' } \\
\text { comments) }\end{array}$} \\
\hline $\begin{array}{l}\text { Additional } \\
\text { Comments }\end{array}$ & $\begin{array}{l}\text { Google } \\
\text { Chrome }\end{array}$ & $\begin{array}{l}\text { Comment 1: Happy Father's } \\
\text { Day to all the dads out there } \\
\text { goo.gl/XMV27d \#throwback } \\
\text { Likes: } 1,192\end{array}$ & $\begin{array}{l}\text { The data set only } \\
\text { includes user-generated } \\
\text { reactions and does not } \\
\text { consider account owner } \\
\text { responses. The } \\
\text { comment was removed } \\
\text { from the data set. }\end{array}$ \\
\hline
\end{tabular}


Table A2: Dear Sophie (2011) - Oldest 100 report for blank, duplicate, and multiple responses.

\begin{tabular}{|c|c|c|c|}
\hline Criteria & User & Comment & Research Notes \\
\hline \multicolumn{4}{|l|}{$\begin{array}{l}\text { Blank } \\
\text { Comments }\end{array}$} \\
\hline \multicolumn{4}{|l|}{$\begin{array}{l}\text { Duplicate } \\
\text { Comments }\end{array}$} \\
\hline \multicolumn{4}{|l|}{$\begin{array}{l}\text { Multiple } \\
\text { Comments } \\
\text { (Consecutive) } \\
\end{array}$} \\
\hline \multicolumn{4}{|l|}{$\begin{array}{l}\text { Multiple } \\
\text { Comments } \\
\text { (Nonconsecutive) } \\
\end{array}$} \\
\hline \multirow{5}{*}{$\begin{array}{l}\text { Multiple } \\
\text { Comments } \\
\text { (Nonconsecutive, } \\
\text { in response to } \\
\text { other users' } \\
\text { comments) }\end{array}$} & hhays 92 & $\begin{array}{l}\text { Comment 1: I teared up a } \\
\text { little, lol. :P } \\
\text { Comment 2: @dominiccss } \\
\text {...um, does it matter? }\end{array}$ & $\begin{array}{l}\text { Combined as one } \\
\text { comment in the data set }\end{array}$ \\
\hline & Huy Ho & $\begin{array}{l}\text { Comment 1: what's the song } \\
\text { used in this video!?. } \\
\text { Comment 2: @garbagecat1 } \\
\text { thank you sir. }\end{array}$ & $\begin{array}{l}\text { Combined as one } \\
\text { comment in the data set }\end{array}$ \\
\hline & $\begin{array}{l}\text { Shamir } \\
\text { Adnan }\end{array}$ & $\begin{array}{l}\text { Comment 1: Thank you for } \\
\text { tracking our daily life } \\
\text { activity... And let the whole } \\
\text { world know about our private } \\
\text { life... } \\
\text { Comment 2: @fakundo01 Am } \\
\text { just saying... ;) }\end{array}$ & $\begin{array}{l}\text { Combined as one } \\
\text { comment in the data set }\end{array}$ \\
\hline & $\begin{array}{l}\text { Prashanth } \\
\text { Akunuri }\end{array}$ & $\begin{array}{l}\text { Comment 1: where's the } \\
\text { favorite button! hehe ! } \\
\text { Comment 2: } 0\end{array}$ & $\begin{array}{l}\text { Combined as one } \\
\text { comment in the data set }\end{array}$ \\
\hline & $\begin{array}{l}\text { flop vingt- } \\
\text { cinq }\end{array}$ & $\begin{array}{l}\text { Comment 1: Well, so good to } \\
\text { have his private life on youtube } \\
\text { picassa etc ! When she'll be an } \\
\text { teenager, the first thing she will } \\
\text { do, is to delete all "her" content } \\
\text { ! } \\
\text { Comment 2: @gheorghe } 3000 \\
\text { yep you're right! She'll try but } \\
\text { her life is stuck in the web }\end{array}$ & $\begin{array}{l}\text { Combined as one } \\
\text { comment in the data set }\end{array}$ \\
\hline
\end{tabular}


Table A3: Your Chrome, Everywhere (2012) - Newest 100 report for blank, duplicate, and multiple responses.

\begin{tabular}{|c|c|c|c|}
\hline Criteria & User & Comment & Research Notes \\
\hline \multirow[t]{2}{*}{$\begin{array}{l}\text { Blank } \\
\text { Comments }\end{array}$} & $\begin{array}{l}\text { Marie } \\
\text { Aquilegye }\end{array}$ & No Comment & Removed from data set \\
\hline & Myline Dee & No Comment & Removed from data set \\
\hline \multicolumn{4}{|l|}{$\begin{array}{l}\text { Duplicate } \\
\text { Comments }\end{array}$} \\
\hline \multirow[t]{4}{*}{$\begin{array}{l}\text { Multiple } \\
\text { Comments } \\
\text { (Consecutive) }\end{array}$} & Khoa Pham & $\begin{array}{l}\text { Comment 1: kkkkkkkkkk pv } \\
\text { zk bschk zpvzkpv bschk zk pv } \\
\text { zk bschk zpvzkpv bschk zk pv } \\
\text { zk bschk zpvzkpv bschk zk } \\
\text { pschk pv bschk bschk pv . pv } \\
\text { zk bschk zpvzkpv bschk zk pv } \\
\text { zk bschk zpvzkpv bschk zk pv } \\
\text { zk bschk zpvzkpv bschk zk } \\
\text { pschk pv pschk bschk pv . pv } \\
\text { zk bschk zpvzkpv bschk zk pv } \\
\text { zk bschk zpvzkpv bschk zk pv } \\
\text { zk bschk zpvzkpv bschk zk pv } \\
\text { zk bschk zpvzkpv bschk zk pv } \\
\text { zk bschk zpvzkpv bschk zk pv } \\
\text {. kkkkkkkkkk bschk zk pv zk } \\
\text { bschk zpvzkpv bschk zk pv zk } \\
\text { bschk zpvzkpv bschk zk pv zk } \\
\text { bschk zpvzkpv pschk zk pv zk } \\
\text { Comment 2: ...bschk zpvzkpv } \\
\text { bschk zk pv }\end{array}$ & $\begin{array}{l}\text { Combined as one } \\
\text { comment in the data set }\end{array}$ \\
\hline & David Ivey & $\begin{array}{l}\text { Comment 1: @TheMillman7 } \\
\text { Comment 2: @vitababkin } 835\end{array}$ & $\begin{array}{l}\text { Combined as one } \\
\text { comment in the data set }\end{array}$ \\
\hline & oatto king & $\begin{array}{l}\text { Comment 1: Free Dom in } \\
\text { World ...same World is Life. } \\
\text { Can Touch everytime } \\
\text { Comment 2: Teacher real... } \\
\text { Have teach with Vedio ...good }\end{array}$ & $\begin{array}{l}\text { Combined as one } \\
\text { comment in the data set }\end{array}$ \\
\hline & wooders 2310 & $\begin{array}{l}\text { Comment 1: because when he } \\
\text { says "and now even here" hes } \\
\text { referring to the fact that } \\
\text { chrome is now available on } \\
\text { iOS because it hasn't always } \\
\text { been where as it was on }\end{array}$ & $\begin{array}{l}\text { Combined as one } \\
\text { comment in the data set }\end{array}$ \\
\hline
\end{tabular}


Table A3 (continued)

\begin{tabular}{|c|c|c|c|}
\hline Criteria & User & Comment & Research Notes \\
\hline \multirow[t]{5}{*}{$\begin{array}{l}\text { Multiple } \\
\text { Comments } \\
\text { (Consecutive) }\end{array}$} & & $\begin{array}{l}\text { iOS because it hasn't always } \\
\text { been where as it was on } \\
\text { android since release. } \\
\text { Comment 2: I don't need } \\
\text { saving by a pretend dead man } \\
\text { in a dress thanks. }\end{array}$ & \\
\hline & Avin 21 & $\begin{array}{l}\text { Comment 1: I freakin love this } \\
\text { commercial. The whole sounds } \\
\text { coming together is awesome! } \\
\text { Comment 2: They're just } \\
\text { showing that Crhome is now } \\
\text { available on the iPhone }\end{array}$ & $\begin{array}{l}\text { Combined as one } \\
\text { comment in the data set }\end{array}$ \\
\hline & $\begin{array}{l}\text { rand42Studio } \\
\mathrm{s}\end{array}$ & $\begin{array}{l}\text { Comment 1: listen! not lisent! } \\
\text { Comment 2: 0:19 are you a } \\
\text { troll, google? } \\
\text { Comment 3: LOLZ. }\end{array}$ & $\begin{array}{l}\text { Combined as one } \\
\text { comment in the data set }\end{array}$ \\
\hline & $\begin{array}{l}\text { Jasper de } \\
\text { Jong }\end{array}$ & $\begin{array}{l}\text { Comment 1: No. } \\
\text { Comment 2: Don't worry, i } \\
\text { won't tell anyone. }\end{array}$ & $\begin{array}{l}\text { Combined as one } \\
\text { comment in the data set }\end{array}$ \\
\hline & Danny Perski & $\begin{array}{l}\text { Comment 1: No, because that } \\
\text { is an iPhone } 4 . \\
\text { Comment 2: It really isn't. }\end{array}$ & $\begin{array}{l}\text { Combined as one } \\
\text { comment in the data set }\end{array}$ \\
\hline \multirow[t]{3}{*}{$\begin{array}{l}\text { Multiple } \\
\text { Comments } \\
\text { (Nonconsecutive) }\end{array}$} & Tom Hyde & $\begin{array}{l}\text { Comment 1: You got Android } \\
\text { 2.3. No. You have ICS, that's } \\
\text { the point I'm making } \\
\text { Comment 2: Hehehe. I never } \\
\text { noticed the comment. Ahh well } \\
\text { you're lucky if you have } \\
\text { gingerbread and it works for } \\
\text { you. }\end{array}$ & $\begin{array}{l}\text { Considered as two } \\
\text { separate comments in } \\
\text { the data set }\end{array}$ \\
\hline & Yuval & $\begin{array}{l}\text { Comment 1: * Replacing the } \\
\text { Safari in the dock to Chrome* } \\
\text { Comment 2: I'm trying to } \\
\text { search it in the Appstore but I } \\
\text { can't find it. Where is it? }\end{array}$ & $\begin{array}{l}\text { Considered as two } \\
\text { separate comments in } \\
\text { the data set }\end{array}$ \\
\hline & $\begin{array}{l}\text { Donovan } \\
\text { Saccone }\end{array}$ & $\begin{array}{l}\text { Comment 1: Haha! Google is } \\
\text { about bringing information and } \\
\text { the joy of communication to }\end{array}$ & $\begin{array}{l}\text { Considered as two } \\
\text { separate comments in } \\
\text { the data set }\end{array}$ \\
\hline
\end{tabular}


Table A3 (continued)

\begin{tabular}{|c|c|c|c|}
\hline Criteria & User & Comment & Research Notes \\
\hline \multirow[t]{2}{*}{$\begin{array}{l}\text { Multiple } \\
\text { Comments } \\
\text { (Nonconsecutive) }\end{array}$} & & $\begin{array}{l}\text { EVERYONE, } \\
\text { EVERYWHERE, ALL THE } \\
\text { TIME. It's not a business } \\
\text { worried about competitors. It's } \\
\text { not about Android or iOS. } \\
\text { Comment 2: It's not the only } \\
\text { owner, but you seem to have } \\
\text { missed my point. It's a smart } \\
\text { move actually, to allow Apple } \\
\text { users to use Chrome. That way } \\
\text { they'll be exposed to Google's } \\
\text { products, and might make a } \\
\text { switch to Android for their } \\
\text { next phone. }\end{array}$ & \\
\hline & $\begin{array}{l}\text { Lukas Frimer } \\
\text { Tholander }\end{array}$ & $\begin{array}{l}\text { Comment 1: } \\
\text { 1. Go to Google Translate } \\
\text { 2. Type that (Or Copy/Paste if } \\
\text { you want..) } \\
\text { 4. Click the speaker. It now } \\
\text { says "Beatbox", insted of } \\
\text { "lisent". } \\
\text { 5. Congratz. You can now hear } \\
\text { Google Translate beatbox! } \\
\text { Comment 2: Sorry. im SO } \\
\text { sorry. Did it hurrrt you? Ooooh } \\
\text { siht does this shti anoie yuo. } \\
\text { Butt i do'nt ca're. Yo'ud } \\
\text { understanded me in dat' } \\
\text { coment, rihgt? Sho STFU. }\end{array}$ & $\begin{array}{l}\text { Considered as two } \\
\text { separate comments in } \\
\text { the data set }\end{array}$ \\
\hline \multirow{2}{*}{$\begin{array}{l}\text { Multiple } \\
\text { Comments } \\
\text { (Nonconsecutive, } \\
\text { in response to } \\
\text { other users' } \\
\text { comments) }\end{array}$} & $\begin{array}{l}\text { Pantellis } \\
\text { Bugatti }\end{array}$ & $\begin{array}{l}\text { Comment 1: will Chrome } \\
\text { have flash player plug in? } \\
\text { Comment 2: when you } \\
\text { download flash or chrome? o.O }\end{array}$ & $\begin{array}{l}\text { Combined as one } \\
\text { comment in the data set }\end{array}$ \\
\hline & $\begin{array}{l}\text { Maxwell } \\
\text { Fong }\end{array}$ & $\begin{array}{l}\text { Comment 1: Flash comes with } \\
\text { Chrome when you download it. } \\
\text { Comment 2: @pantelos96 } \\
\text { Chrome. A Flash Player is } \\
\text { already installed in Chrome. } \\
\text { That means no messy setup or } \\
\text { updates. }\end{array}$ & $\begin{array}{l}\text { Combined as one } \\
\text { comment in the data set }\end{array}$ \\
\hline
\end{tabular}


Table A4: Your Chrome, Everywhere (2012) - Oldest 100 report for blank, duplicate, and multiple responses.

\section{Your Chrome, Everywhere - Oldest 100}

Criteria

Blank Comments

\begin{tabular}{|l|l|l|}
\hline Duplicate & Parmeet & Comment 1: Google really did
\end{tabular}

Comments

Multiple

Comments

(Consecutive)

Bhatia

David Albizu

Comment 2: Google really does live up to its motto

Comment 1: Just type in chrome and it should show up

Comment 2: To get Chrome for iPhone just type in Chrome and it should show up

\begin{tabular}{l|l}
\hline Pete Kemp & Comment 1: It says it's been
\end{tabular}
pulled from the store??? :(

Comment 2: "The item you tried to buy is no longer available" : ( :

xFelicianoX Comment 1: Same here, I love it

Comment 2: Just go to safari and type google.com/chrome/mobile. That's how I got it.

\begin{tabular}{|c|c|c|}
\hline $\begin{array}{l}\text { Ruperto } \\
\text { Quintero }\end{array}$ & $\begin{array}{l}\text { Comment 1: IT'S A IPHONE } \\
\text { 5? SEE SCREEN } \\
\text { Comment 2: SECOND } 52\end{array}$ & $\begin{array}{l}\text { Combined as one } \\
\text { comment in the data set }\end{array}$ \\
\hline $\begin{array}{l}\text { Mohammed } \\
\text { Babur }\end{array}$ & $\begin{array}{l}\text { Comment 1: they're just } \\
\text { giving apple a little love tap } \\
\text { Comment 2: hah. Your funny } \\
\text { Comment 3: I can't le find }\end{array}$ & $\begin{array}{l}\text { Combined as one } \\
\text { comment in the data set }\end{array}$ \\
\hline TheMr1Boy & $\begin{array}{l}\text { Comment 1: Wow this is } \\
\text { gonna be cool!!! } \\
\text { Comment 2: It's not out yet, } \\
\text { somewhere today }\end{array}$ & $\begin{array}{l}\text { Combined as one } \\
\text { comment in the data set }\end{array}$ \\
\hline Thre3Dawg & $\begin{array}{l}\text { Comment 1: Google develops } \\
\text { and owns Android though. } \\
\text { Comment 2: Welcome to the } \\
\text { future, iOS users. } 1 \text { step at a } \\
\text { time guys. }\end{array}$ & $\begin{array}{l}\text { Combined as one } \\
\text { comment in the data set }\end{array}$ \\
\hline
\end{tabular}


Table A4 (continued)

\begin{tabular}{|c|c|c|c|}
\hline Criteria & User & Comment & Research Notes \\
\hline $\begin{array}{l}\text { Multiple } \\
\text { Comments } \\
\text { (Consecutive) }\end{array}$ & jaydekaytv & $\begin{array}{l}\text { Comment 1: I'm currently not } \\
\text { seeing this for iOS in the App } \\
\text { Store... } \\
\text { Comment 2: is this only } \\
\text { avilable through no-App-Store } \\
\text { means? }\end{array}$ & $\begin{array}{l}\text { Combined as one } \\
\text { comment in the data set }\end{array}$ \\
\hline \multirow[t]{2}{*}{$\begin{array}{l}\text { Multiple } \\
\text { Comments } \\
\text { (Nonconsecutive) }\end{array}$} & xFelicianoX & $\begin{array}{l}\text { Comment 1: Same here, I love } \\
\text { it. Just go to safari and type } \\
\text { google.com/chrome/mobile. } \\
\text { That's how I got it. } \\
\text { Comment 2: Apple letting it } \\
\text { through is surprising, Google } \\
\text { already has plenty of apps on } \\
\text { the App store. }\end{array}$ & $\begin{array}{l}\text { Considered as two } \\
\text { separate comments in } \\
\text { the data set }\end{array}$ \\
\hline & The3Dawg & $\begin{array}{l}\text { Comment 1: Google develops } \\
\text { and owns Android though. } \\
\text { Welcome to the future, iOS } \\
\text { users. } 1 \text { step at a time guys. } \\
\text { Comment 2: As much as I } \\
\text { believe that everyone should be } \\
\text { able to experience chrome for } \\
\text { mobile, I'm a little bitter that } \\
\text { google has decided to put it on } \\
\text { iOS. Chrome isn't one of the } \\
\text { reasons I'm on android, but it's } \\
\text { a nice distinguishing GOOGLE } \\
\text { feature. } \\
\text { It's like google doesn't want } \\
\text { Android to succeed.. }\end{array}$ & $\begin{array}{l}\text { Considered as two } \\
\text { separate comments in } \\
\text { the data set }\end{array}$ \\
\hline $\begin{array}{l}\text { Multiple } \\
\text { Comments } \\
\text { (Nonconsecutive, } \\
\text { in response to } \\
\text { other users' } \\
\text { comments) }\end{array}$ & & & \\
\hline
\end{tabular}




\section{Appendix B: Part I: Comparative Analysis NVivo Final Coding}

The following Figures B1 and B2 in Appendix B provide screenshots of the final coding in NVivo for each advertisement. The summary of data indicates the number of responses grouped into the following predefined categories: reactional, non-reactional other, and subcategories: positive, negative, neutral, foreign language, non-related content and non-legible spam. The corresponding Table 4.1 in the Discussion of Results section of the MRP provides a summary of the results in percentage of comments per set of 200 responses, per advertisement.

Figure B1: Dear Sophie (2011) NVivo Final Coding

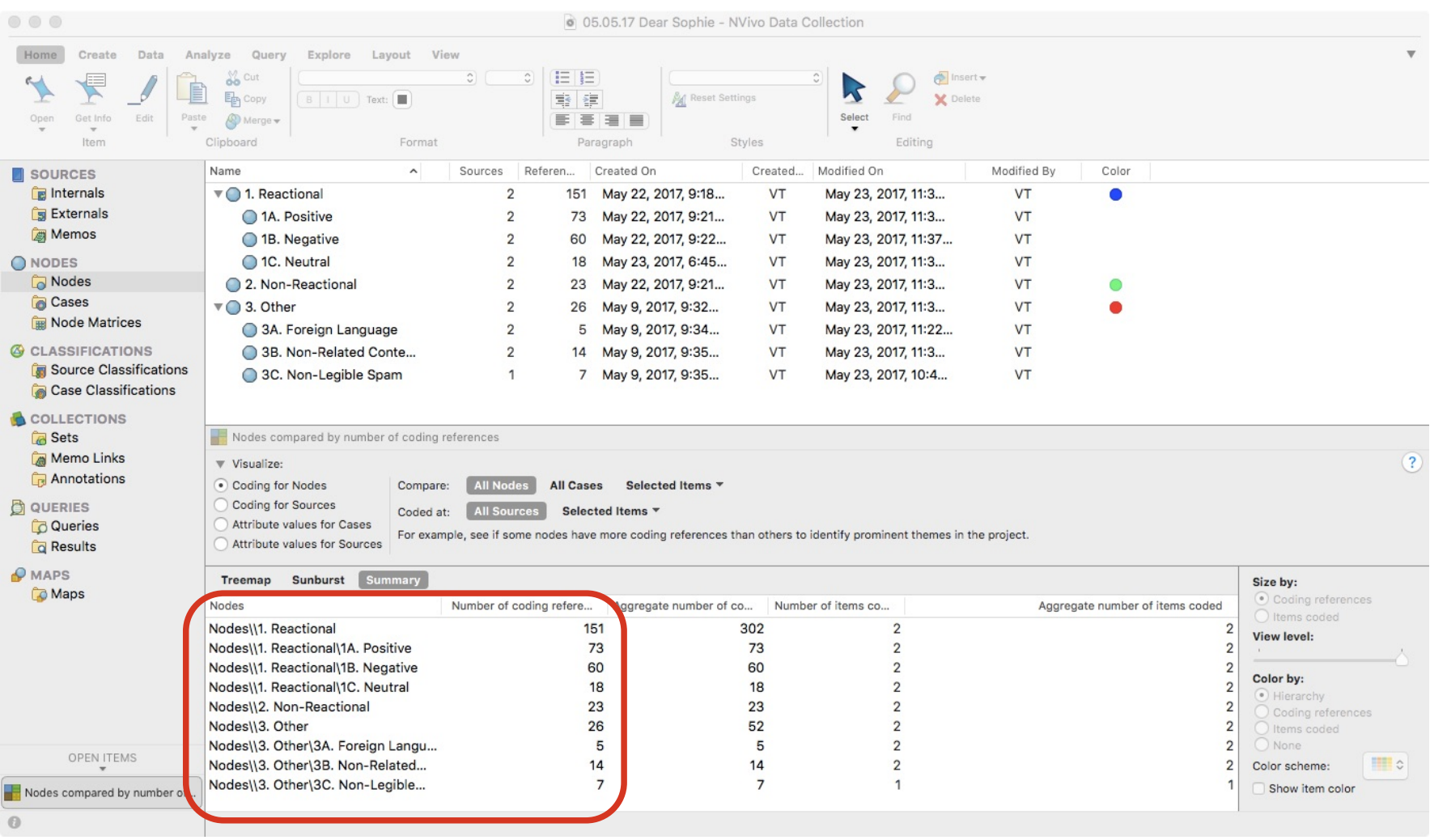

\begin{tabular}{|c|c|}
\hline Nodes & Number of Coding References \\
\hline Nodes $\backslash \backslash 1$. Reactional & 151 \\
\hline Nodes $\backslash \backslash 1$. Reactional $\backslash 1$ A. Positive & 73 \\
\hline Nodes $\backslash \backslash 1$. Reactional $\backslash 1 B$. Negative & 60 \\
\hline Nodes $\backslash \backslash 1$. Reactional $\backslash 1 C$. Neutral & 18 \\
\hline Nodes $\backslash \backslash 2$. Non-Reactional & 23 \\
\hline Nodes $\backslash \backslash 3$. Other & 26 \\
\hline Nodes $\backslash \backslash 3$. Other $\backslash 3 \mathrm{~A}$. Foreign Language & 5 \\
\hline Nodes $\backslash \backslash 3$. Other $\backslash 3 B$. Non-Related Content & 14 \\
\hline Nodes \\
3. Other $\backslash 3 \mathrm{C}$. Non-Legible Spam & 7 \\
\hline
\end{tabular}


Figure B2: Your Chrome, Everywhere (2012) NVivo Final Coding

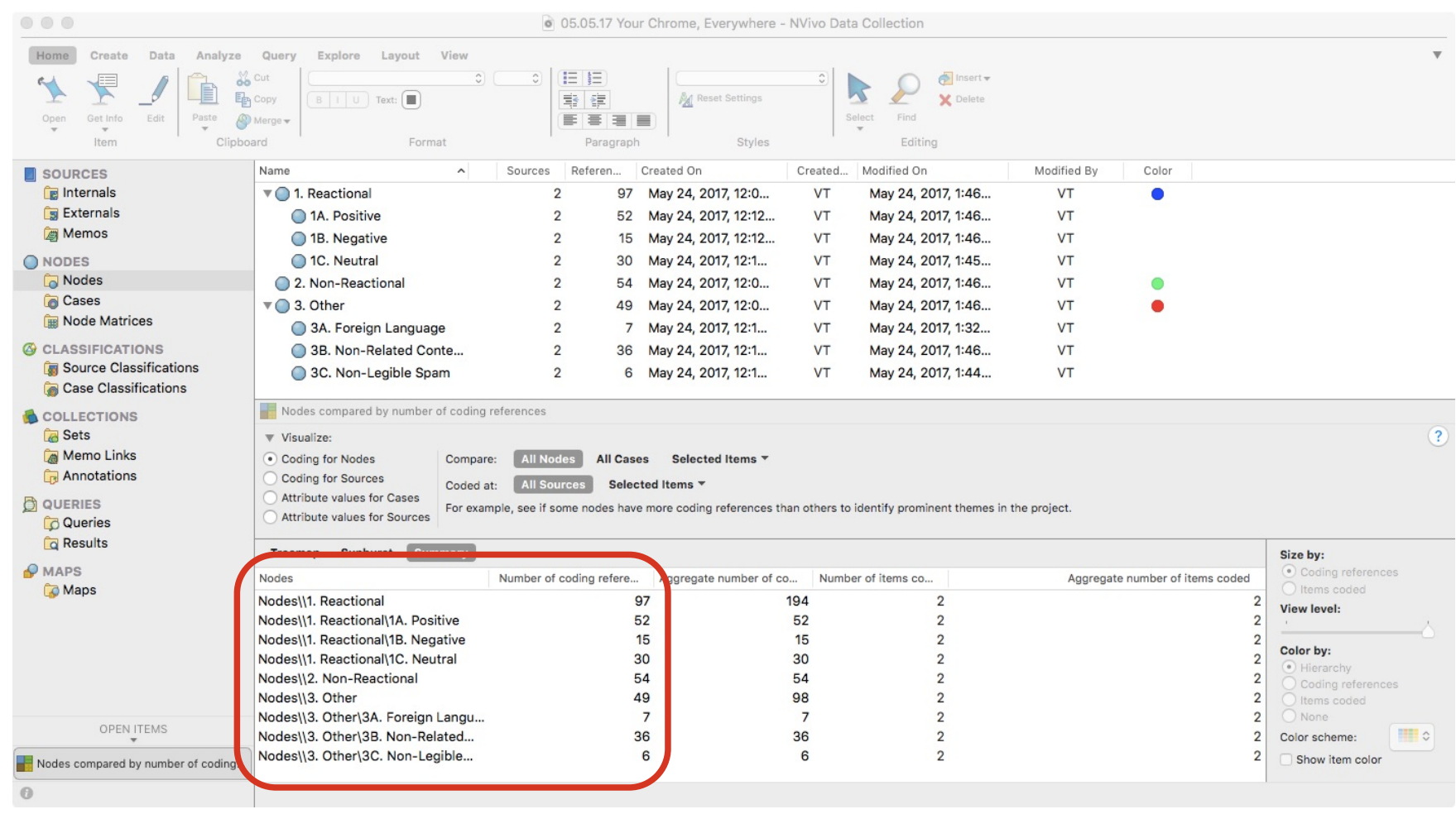

\begin{tabular}{|c|c|}
\hline Nodes & Number of Coding References \\
\hline Nodes $\backslash \backslash 1$. Reactional & 97 \\
\hline Nodes $\backslash \backslash 1$. Reactional $\backslash 1$ A. Positive & 52 \\
\hline Nodes $\backslash \backslash 1$. Reactional $\backslash 1 B$. Negative & 15 \\
\hline Nodes $\backslash \backslash 1$. Reactional $\backslash 1 C$. Neutral & 30 \\
\hline Nodes $\backslash \backslash 2$. Non-Reactional & 54 \\
\hline Nodes $\backslash \backslash 3$. Other & 49 \\
\hline Nodes $\backslash \backslash 3$. Other $\backslash 3 \mathrm{~A}$. Foreign Language & 7 \\
\hline Nodes $\backslash \backslash 3$. Other $\backslash 3 B$. Non-Related Content & 36 \\
\hline Nodes $\backslash \backslash 3$. Other $\backslash 3$ C. Non-Legible Spam & 6 \\
\hline
\end{tabular}




\section{Appendix C: Part I: Comparative Analysis Vanity Metrics}

The following Figures $\mathrm{C} 1$ and $\mathrm{C} 2$ provide a screenshot of each advertisement, indicating vanity metrics as per Table 4.2 in the Discussion of Results section of the MRP. The screenshots were taken on May 5, 2017.

Figure C1: Dear Sophie (2011) Screenshot as of May 5, 2017

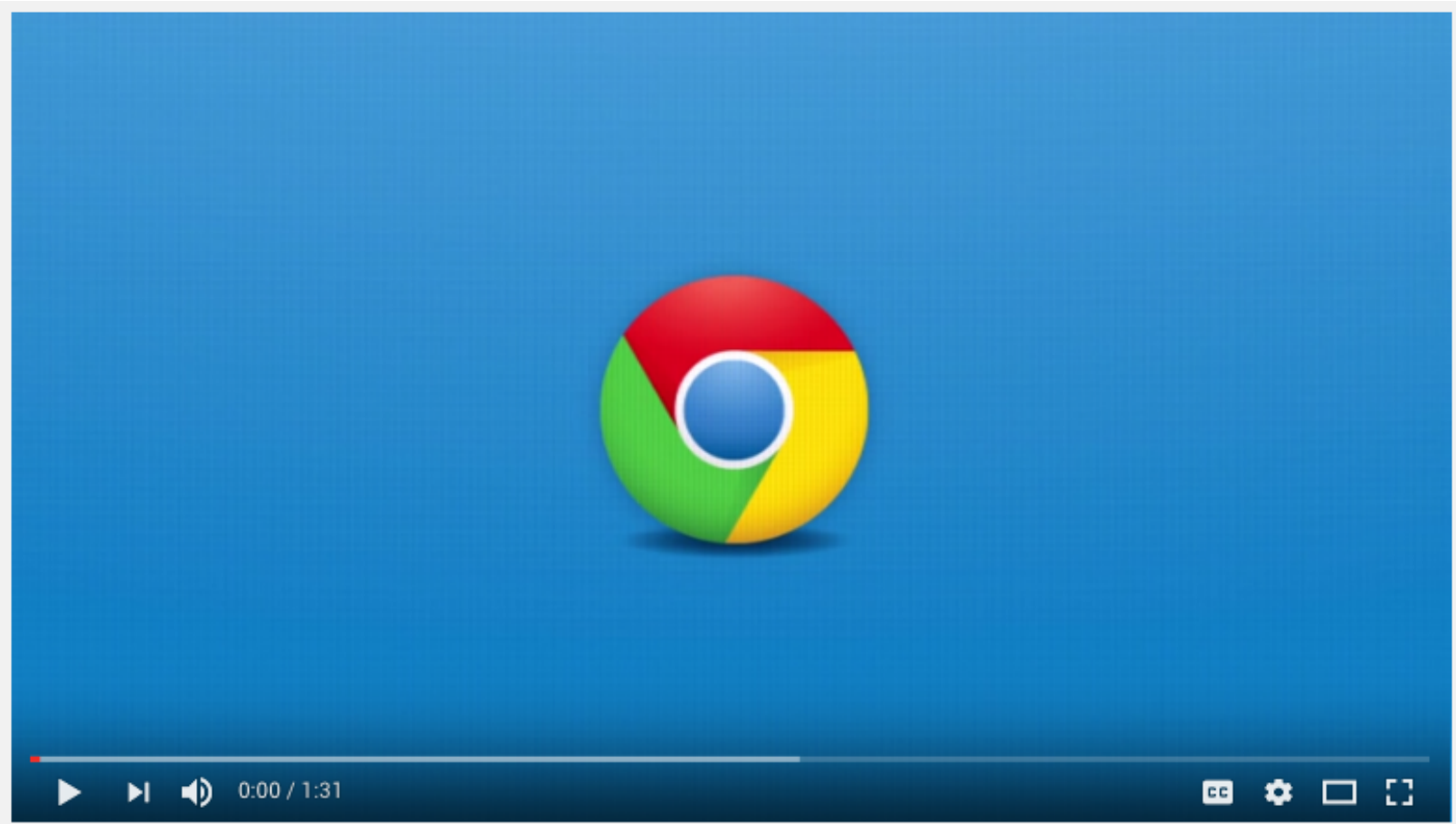

Google Chrome: Dear Sophie

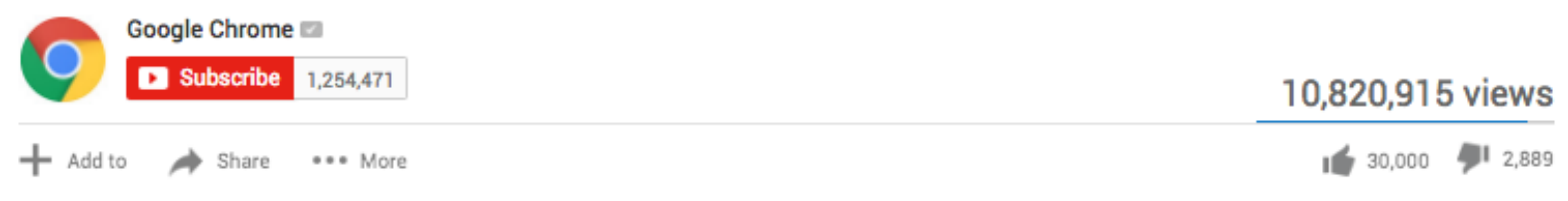

Published on May 2, 2011

A father uses the web to share memories with his daughter as she grows up in this video depiction.

Music by: Ingrid Michaelson 
Figure C2: Your Chrome, Everywhere (2012) Screenshot as of May 5, 2017

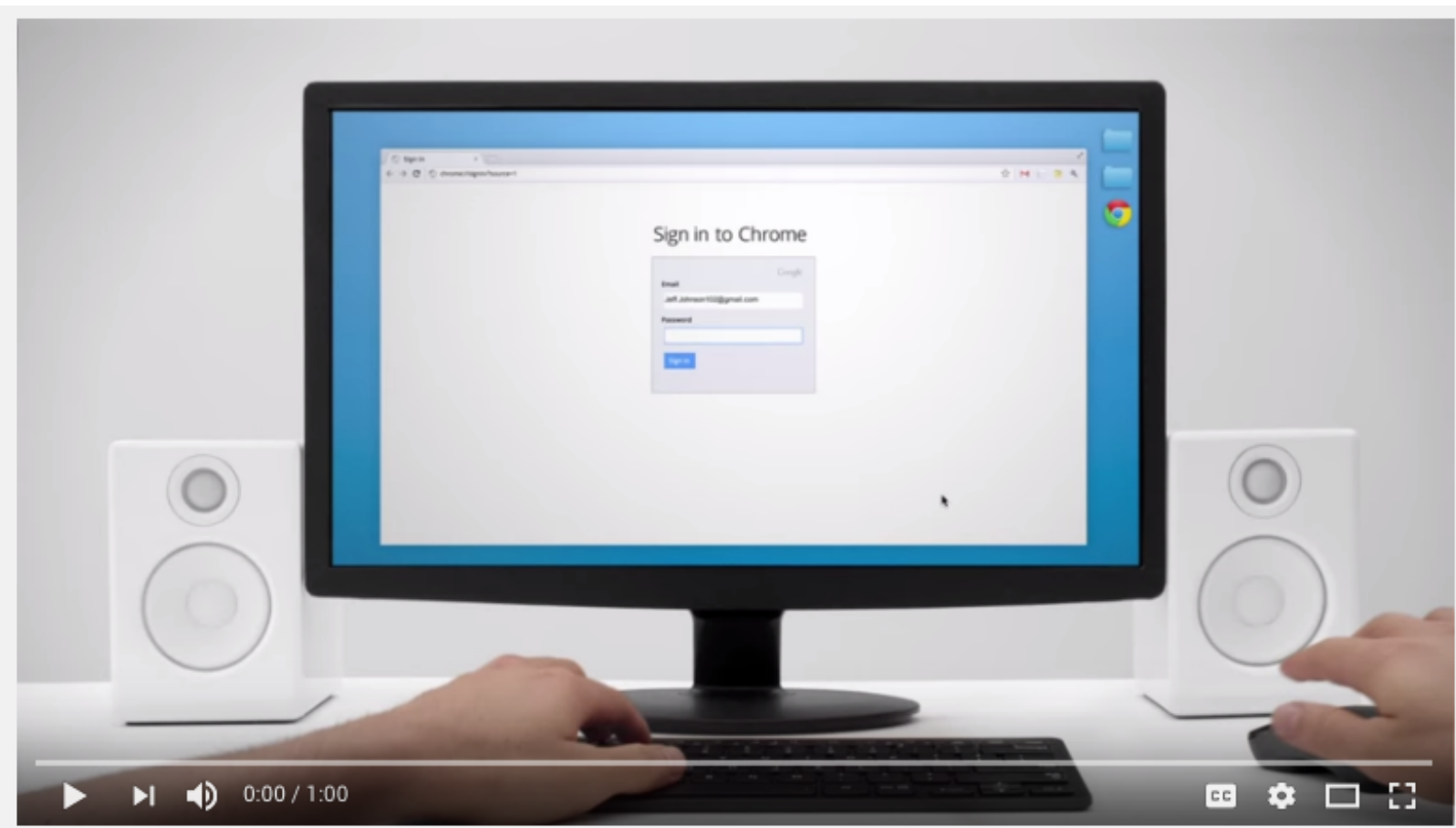

Your Chrome, Everywhere

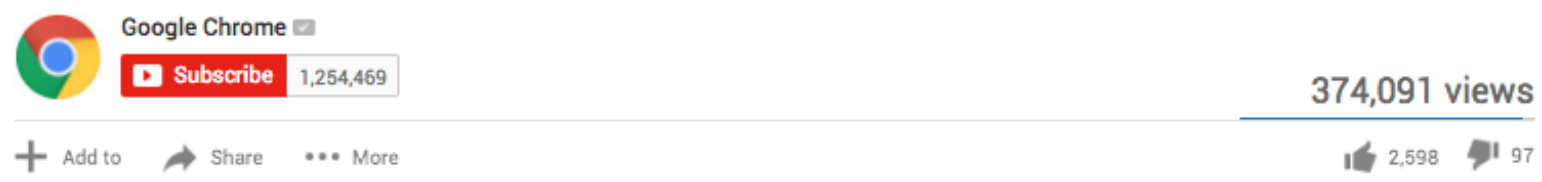

\section{Published on Jun 28, 2012}

Sign-in and seamlessly experience your personalized web across desktops, phones, and tablets with Chrome for Mobile.

http://google.com/chrome/mobile

Category Science \& Technology

License Standard YouTube License

SHOW LESS

COMMENTS $\cdot 286$ 


\section{Appendix D: Part I: Comparative Analysis Dear Sophie (2011) Data Set}

The following Tables D1, D2, D3, D4, D5, D6, and D7 in Appendix D provide summaries of the data collected for Dear Sophie (2011), as coded in NVivo.

Table D1: Dear Sophie (2011) - 1.Reactional/1A.Positive Responses

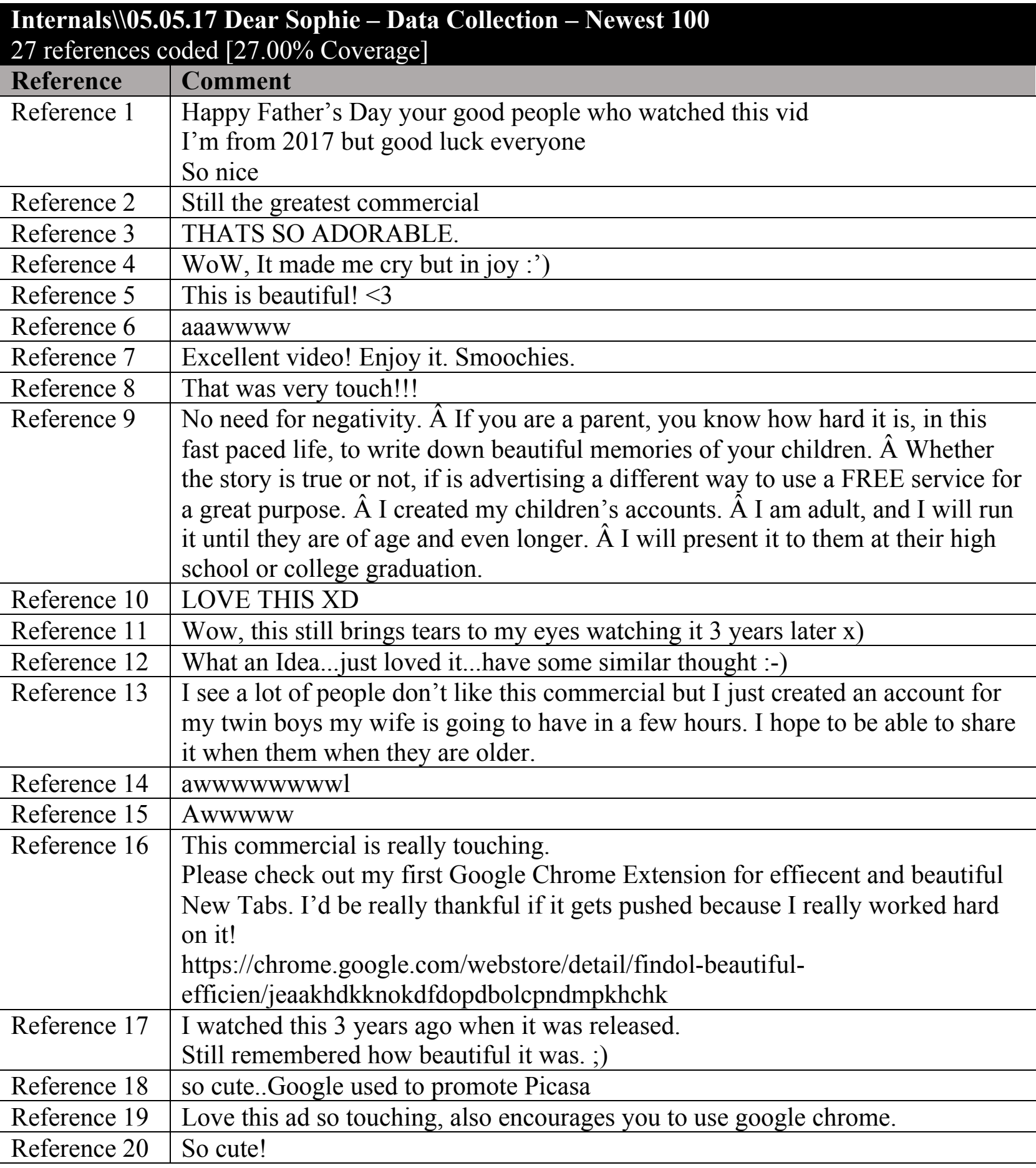


Table D1 (continued)

\begin{tabular}{|c|c|}
\hline Reference & Comment \\
\hline Reference 21 & Best \\
\hline Reference 22 & This is adorable. $\partial \ddot{Y}_{\mid}^{\sim} \hat{\mathrm{a}}^{\alpha^{0}} i, \quad \partial \ddot{Y}^{\sim} \check{S}^{\prime} \delta \ddot{Y}^{\sim}$ \\
\hline Reference 23 & Daniel Lee + marketing team and Google, you are incredibly talented. \\
\hline Reference 24 & So adorable! Wonderful ad! The best! \\
\hline Reference 25 & This video is very cute and happy! : : ( \\
\hline Reference 26 & i like \\
\hline Reference 27 & Google ads are really inspirational it's amazing what you can do with the web \\
\hline \multicolumn{2}{|c|}{$\begin{array}{l}\text { Internals } \mid \backslash 05.05 .17 \text { Dear Sophie - Data Collection - Oldest } 100 \\
46 \text { references coded [46.00\% Coverage] }\end{array}$} \\
\hline Reference & Comment \\
\hline Reference 1 & $\begin{array}{l}\text { I love that Google promotes the web more than their actual products. What if } \\
\text { BMW could promote just driving. }\end{array}$ \\
\hline Reference 2 & Ouuun so sweet $; ;<3$ \\
\hline Reference 3 & $\begin{array}{l}\text { gawawhwahaw this is so swwwwwweeet ;-; } \\
\text { what if the dad isn't always around the girl when she's older } \\
\text { she can always look back into the memories -.- }\end{array}$ \\
\hline Reference 4 & love it! \\
\hline Reference 5 & ooouuunnn :') \\
\hline Reference 6 & The best add from an internet browser ever! \\
\hline Reference 7 & $\begin{array}{l}\text { @ Robstailey He creates an email account for his daughter and sending the } \\
\text { emails to that address. :-) }\end{array}$ \\
\hline Reference 8 & BRAVO! \\
\hline Reference 9 & Internet, I love you $<3$ \\
\hline Reference 10 & that's fantastic I wanna do that myself in the future \\
\hline Reference 11 & $\begin{array}{l}\text { This is GENIUS. First in the marketing approach......way to hit 'em where it } \\
\text { hurts. Second, because well, why the shit didn't my crazy scrapbooking, picture- } \\
\text { taking, journaling ass think to do this a long time ago??? I always forget to write } \\
\text { down all the funny things the kids do but this is so much easier! I am setting up } \\
\text { thier gmail accounts immediately :) Also, Google...... love you. }\end{array}$ \\
\hline Reference 12 & $\begin{array}{l}\text { So so beauty!!! } \\
\text { :,) }\end{array}$ \\
\hline Reference 13 & $\begin{array}{l}\text { @ Hiiyuki } \\
\text { :O make a video like this if you do! =) }\end{array}$ \\
\hline Reference 14 & I am SO gonna do this if I'll have a child! :] \\
\hline Reference 15 & Yep. \\
\hline Reference 16 & awww, i love thiss :D \\
\hline Reference 17 & Amazing stuff. \\
\hline Reference 18 & very well done video. \\
\hline Reference 19 & 6 people pressed the 'I dislike button' by mistake.... \\
\hline
\end{tabular}


Table D1 (continued)

\begin{tabular}{|c|c|}
\hline Reference & Comment \\
\hline Reference 20 & i love that outro \\
\hline Reference 21 & beautiful ad...I love it :) \\
\hline Reference 22 & awesome. kudos. to both google \& their advertising agency BBH NY \\
\hline Reference 23 & Whoever came up with this video is simply a genius. \\
\hline Reference 24 & $\begin{array}{l}\text { wow!!! } \\
\text { i would like to make a e diary like this for my kid!!! }\end{array}$ \\
\hline Reference 25 & $\begin{array}{l}\text { I'm a super Apple Fan and a Dad of twins.... Google... you had me at "dear } \\
\text { Sophie".... }\end{array}$ \\
\hline Reference 26 & As a father myself to two girls, this video really touched me. \\
\hline Reference 27 & $\begin{array}{l}\text { Lovely video. Just waiting for the parody where in the end says: "Love, your } \\
\text { dad, Joseph Fritzl." }\end{array}$ \\
\hline Reference 28 & dawwww this was so sweet \\
\hline Reference 29 & I love how one of the video tags is "salt" \\
\hline Reference 30 & this is so heart warming! \\
\hline Reference 31 & Inspired me to do something similar methinks! \\
\hline Reference 32 & thumbs up if you love the ending animation of chrome \\
\hline Reference 33 & $\begin{array}{l}\text { I love these commercials. Such a way that they can make an internet browser } \\
\text { more than just a browser. It is everything right there. That is why I'm a proud } \\
\text { Chrome user. : } 3\end{array}$ \\
\hline Reference 34 & These sort of videos always makes my heart go warm for some reason. \\
\hline Reference 35 & Hehe, really good job Google. \\
\hline Reference 36 & Beautiful. I love seeing Google advocate wholesome, traditional values. \\
\hline Reference 37 & Nice Job Google, Pure love \\
\hline Reference 38 & Google 4 life :D \\
\hline Reference 39 & $\begin{array}{l}\text { where's the favorite button! hehe ! } \\
0\end{array}$ \\
\hline Reference 40 & $\begin{array}{l}\text { This is the most innovative idea that I have ever seen the internet used for. If I } \\
\text { am ever diagnosed with Alzheimer's, I'm going to want my kids to e-mail me } \\
\text { my life history and what-not to keep me up to date. }\end{array}$ \\
\hline Reference 41 & love this its such a great idea $: \mathrm{D}^{\wedge} \wedge \wedge$ \\
\hline Reference 42 & $<3$ \\
\hline Reference 43 & Great spot! Reminds me of my own daughter! \\
\hline Reference 44 & This is such a wonderful video : $\hat{\mathrm{A}}^{\prime} 3$ \\
\hline Reference 45 & $\operatorname{cool~O.O~}$ \\
\hline Reference 46 & $\begin{array}{l}\text { @qwrasw Well that added much to the world, twice. } \\
\text { Thumbs up if you are a googler, a chromer, a gmailer, a googlemapser, a go.... } \\
\text { well you get the idea :-) }\end{array}$ \\
\hline
\end{tabular}


Table D2: Dear Sophie (2011) - 1.Reactional/1B. Negative Responses

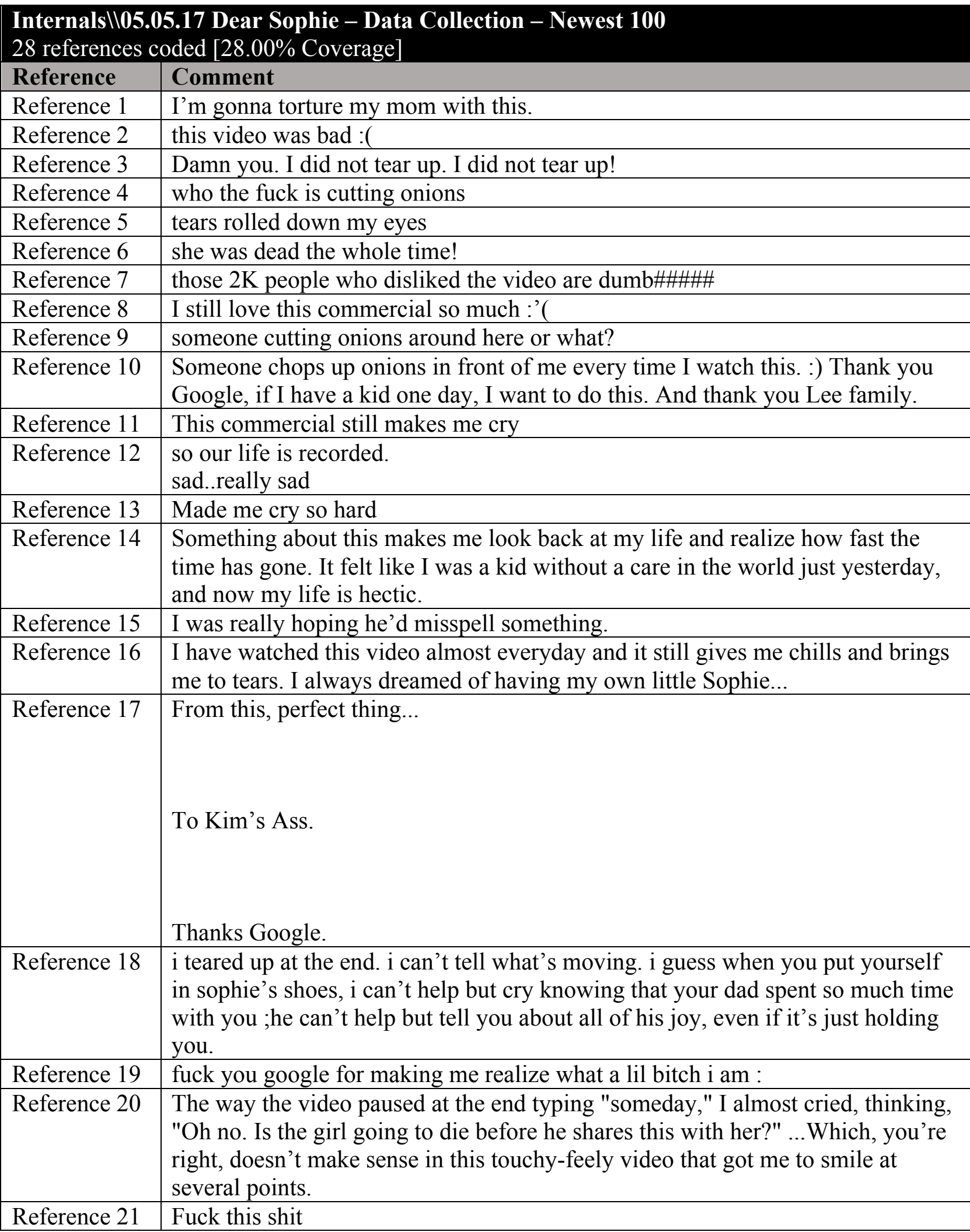


Table D2 (continued)

\begin{tabular}{|c|c|}
\hline Reference & Comment \\
\hline Reference 22 & $\begin{array}{l}\text { I told myself I wouldn't do this.... } \\
\text { Oh god, it always gets me. }\end{array}$ \\
\hline Reference 23 & $\begin{array}{l}\text { Sad to know that Google, that Google Will abuse Sophie and her information. } \\
\text { By selling her information, to rulers and Big companies. }\end{array}$ \\
\hline Reference 24 & Watching these ads again still makes me tear up. Amazing, Google. \\
\hline Reference 25 & $\begin{array}{l}2724 \hat{A} \text { thumbs down ??? } \\
\text { geez }\end{array}$ \\
\hline Reference 26 & $\begin{array}{l}\text { I often come to see this commercial when I am sad.. This } 1 \text { minute } 31 \text { sec video } \\
\text { such an amazing life embedded into it. Wow.. simply wow.. Hats off to the } \\
\text { makers. and } 2720 \text { dislikers.. what do like guyz!!! come on.. have a life }\end{array}$ \\
\hline Reference 27 & this is gay af \\
\hline Reference 28 & So Sad, Yet So Happy! :'( \\
\hline \multicolumn{2}{|c|}{$\begin{array}{l}\text { Internals } \backslash \text { 05.05.17 Dear Sophie - Data Collection - Oldest } 100 \\
32 \text { references coded [32.00\% Coverage] }\end{array}$} \\
\hline Reference & Comment \\
\hline Reference 1 & No those aren't goosebumps on my skin, and those definitely aren't tears either. \\
\hline Reference 2 & or...you could just spend more time with your kid. \\
\hline Reference 3 & hate commercials that make me cry. in a good way. \\
\hline Reference 4 & $\begin{array}{l}\text { Dear Sophie, } \\
\text { I decided to store all your childhood memories in Google Wave so you can see } \\
\text { them all in one convenient location when you're older. Oh wait, scrap that, they } \\
\text { cancelled it. }\end{array}$ \\
\hline Reference 5 & Marketing consultants take note - make people fecking cry! \\
\hline Reference 6 & Dear tears, \\
\hline Reference 7 & Wow... 23 people don't have souls \\
\hline Reference 8 & who the fuck is he sending them to??! \\
\hline Reference 9 & $\begin{array}{l}\text { like this if you think those who have disliked this video are Morons and have no } \\
\text { feelings. }\end{array}$ \\
\hline Reference 10 & $\begin{array}{l}\text { I wonder what the chinese tiger mom would be emailing her daughter. "Get off } \\
\text { the computer! PIANO! PIANO! You LOSER! }\end{array}$ \\
\hline Reference 11 & At Google, we have no problem using children as a marketing device. \\
\hline Reference 12 & $\begin{array}{l}\text { I teared up a little, lol. :P } \\
\text { @,dominiccss ...um, does it matter? }\end{array}$ \\
\hline Reference 13 & hmm kind of creepy. \\
\hline Reference 14 & $\begin{array}{l}\text { What use is an email address full of memories in the post apocalyptic } \\
\text { wasteland? }\end{array}$ \\
\hline Reference 15 & Almost bring tears to my eyes. Very nice video \\
\hline
\end{tabular}


Table D2 (continued)

\begin{tabular}{|l|l|}
\hline Reference & Comment \\
\hline Reference 16 & $\begin{array}{l}\text { WikiLeaks founder Julian Assange says Facebook, Google, and Yahoo are } \\
\text { actually tools for the U.S. intelligence community. What do you think after } \\
\text { watching this video? Google don't want you to have stuff on your hard drive. } \\
\text { They want you to store them in the "cloud" so they know who you are and what } \\
\text { you are doing ALL THE TIME. }\end{array}$ \\
\hline Reference 17 & $\begin{array}{l}\text { So Google Chrome is just for parents who creepily write their children to an } \\
\text { email account? }\end{array}$ \\
\hline Reference 18 & $\begin{array}{l}\text { Well, so good to have his private life on youtube picassa etc ! When she'll be an } \\
\text { teenager, the first thing she will do, is to delete all "her" content ! } \\
\text { @gheorghe3000 yep you're right ! She'll try but her life is stuck in the web }\end{array}$ \\
\hline Reference 19 & $\begin{array}{l}\text { When she'll be an adult there won't be internet anymore and people would fight } \\
\text { for survival. }\end{array}$ \\
\hline Reference 20 & $\begin{array}{l}\text { It's very nice, but it does feel a little like they have sat there going 'How can we } \\
\text { make people cry?' }\end{array}$ \\
\hline Reference 21 & $\begin{array}{l}\text { I almost cried... } \\
\text { so impresive }\end{array}$ \\
\hline Reference 22 & I didn't cry, the people around me said I did. \\
\hline Reference 23 & if this didn't make you cry, something is wrong... very touching \\
\hline Reference 24 & omgaah this totally made me cryy! \\
\hline Reference 25 & $\begin{array}{l}\text { Um, isn't it highly likely that someone out there has that email address, even if it } \\
\text { isn't Sophie Lee, and now it's public and open? }\end{array}$ \\
\hline Reference 26 & Oh dammit, I cried. \\
\hline Reference 27 & So many people are going to start emailing that account... > > \\
\hline Reference 28 & $\begin{array}{l}\text { Thank you for tracking our daily life activity... and let the whole world know } \\
\text { about our private life... } \\
\text { @fakundo01 Am just saying...;) }\end{array}$ \\
\hline Reference 29 & tears....Sophie is a lucky girl. \\
\hline Reference 30 & *starts crying* \\
\hline Reference 31 & $\begin{array}{l}\text { to dear Hacker, } \\
\text { please don't hack that account. }\end{array}$ \\
\hline Reference 32 & wow. that just brought me to tears! ;( \\
\hline
\end{tabular}

Table D3: Dear Sophie (2011) - 1.Reactional/1C. Neutral Responses

\begin{tabular}{|c|c|}
\hline \multicolumn{2}{|c|}{$\begin{array}{l}\text { Internals } \backslash \mathbf{0 5 . 0 5 . 1 7} \text { Dear Sophie - Data Collection - Newest } 100 \\
7 \text { references coded [7.00\% Coverage] }\end{array}$} \\
\hline Reference & Comment \\
\hline Reference 1 & I don't get it. \\
\hline Reference 2 & $\begin{array}{l}\text { Based on the people's behavior in the comment section, google's advertisers has } \\
\text { effectively applied the "evocation strategy". }\end{array}$ \\
\hline
\end{tabular}


Table D3 (continued)

\begin{tabular}{|c|c|}
\hline Reference & Comment \\
\hline Reference 3 & $\begin{array}{l}\text { Dear Sophie, } \\
\text { why did I make you an E-Mail account? }\end{array}$ \\
\hline Reference 4 & $\begin{array}{l}\text { I started one for my son - I just tweaked the year on his bd to say he was old } \\
\text { enough. So what? Same idea. Same functionality. }\end{array}$ \\
\hline Reference 5 & What does he say at $0: 18 ?$ \\
\hline Reference 6 & What is the name of the piano piece playing? \\
\hline Reference 7 & $\begin{array}{l}\text { Radio station 2Day FM in Sydney made a pathetic attempt to steal this idea on } \\
\text { their Facebook page in order to try and make themselves appear creative and } \\
\text { original........they are like } 3 \text { years late with this idea....... }\end{array}$ \\
\hline \multicolumn{2}{|c|}{$\begin{array}{l}\text { Internals } \backslash \text { 05.05.17 Dear Sophie - Data Collection - Oldest } 100 \\
11 \text { references coded [11.00\% Coverage] }\end{array}$} \\
\hline Reference & Comment \\
\hline Reference 1 & They stole this from dearscarlet.tumblr.com. \\
\hline Reference 2 & @InfoPoet it is the same girl. \\
\hline Reference 3 & $\begin{array}{l}\text { They used a chinese girl so you couldn't tell that it wasn't the same girl growing } \\
\text { up. }\end{array}$ \\
\hline Reference 4 & soooo jw...why didn't he just tell her in person \\
\hline Reference 5 & @ Robstailey his daughter... did you not watch it? \\
\hline Reference 6 & baby is also a powerful marketing device \\
\hline Reference 7 & $\begin{array}{l}\text { 2030. Chrome logo still looks like it was from a high school project. Happy } \\
\text { Birthday! }\end{array}$ \\
\hline Reference 8 & I love the little animation of the icon in the end! \\
\hline Reference 9 & $\begin{array}{l}\text { just hope there aint no amazon style disk crash that loses all data... external } \\
\text { backups ftw. }\end{array}$ \\
\hline Reference 10 & I use every google product and more in this video. \\
\hline Reference 11 & $\begin{array}{l}\text { what's the song used in this video!?. } \\
\text { @garbagecat1 thank you sir. }\end{array}$ \\
\hline
\end{tabular}

Table D4: Dear Sophie (2011) - 2.Non-Reactional

Internals $\backslash$ 05.05.17 Dear Sophie - Data Collection - Newest 100
\begin{tabular}{|l|l|} 
17 references coded [17.00\% Coverage] \\
Reference & Comment \\
\hline Reference 1 & $\begin{array}{l}\text { Hello, please can you tell me why this is no longer an option? I created an email } \\
\text { account for my son last year, it has been disabled.... Nobody seems to respond to } \\
\text { twitter either? It's pathetic that you market something like this in 2011, but now } \\
\text { I can't do something like this??? Please explain. }\end{array}$ \\
\hline Reference 2 & gijk \\
\hline Reference 3 & Emalis? Who writes those anymore? \\
\hline
\end{tabular}


Table D4 (continued)

\begin{tabular}{|c|c|}
\hline Reference & Comment \\
\hline Reference 4 & $\begin{array}{l}\text { They should do an updated one with the new software! I would also love if they } \\
\text { could show us how to do this for future kids...maybe they could make a (FREE) } \\
\text { program...call it Google Future. :) You could write your kids letters, leave them } \\
\text { video messages from you, save photos...GET ON IT GOOGLE! }\end{array}$ \\
\hline Reference 5 & I need help on how to email photos \\
\hline Reference 6 & $\begin{array}{l}\text { I sent daddy advice e-mails to my son at his gmail account until they figured out } \\
\text { he was too young to have an account and locked us all out of it. Now I can't } \\
\text { access the emails and they are lost for ever. Sucks! }\end{array}$ \\
\hline Reference 7 & $\begin{array}{l}\text { this is me sherry Patterson } \\
\text { can someone help me get back on Facebook plz }\end{array}$ \\
\hline Reference 8 & $\begin{array}{l}\text { ironically, Google don't allow google Accounts for anyone under } 13 \ldots \text { sooo.... } \\
\text { yeah! }\end{array}$ \\
\hline Reference 9 & $\begin{array}{l}\text { The thing is that this video defeats itself because if you enter the childrens ages } \\
\text { into their profile they will delete the account.. because you have to be } 13+\text { to } \\
\text { hold an account. }\end{array}$ \\
\hline Reference 10 & thats untrue. noone under 13 can get a google account \\
\hline Reference 11 & $\begin{array}{l}\text { Shame this is utter bollocks because you can't create a gmail account for anyone } \\
\text { under the age of } 13 \text {. }\end{array}$ \\
\hline Reference 12 & $\begin{array}{l}\text { This advertisment is false advertising, and children are not even allowed on } \\
\text { Gmail till 13. My brother can't even get Minecraft because of this }\end{array}$ \\
\hline Reference 13 & $\begin{array}{l}\text { Is this really possible??? } \\
\text { Creating an account for a person who just born... :/ }\end{array}$ \\
\hline Reference 14 & $\begin{array}{l}\text { The problem is that google chrome will not let me do what this video shows, in } \\
\text { gfact it has locked me out of adding an account now, after trying to create an } \\
\text { account for my unborn child, says the account is to young, also it states you need } \\
\text { a previous email address, but what happens if this is your first email address, } \\
\text { anyone who can help? } \\
\text { Even if you can tell me how to get rid of the refusal to allow me to now add any } \\
\text { account. }\end{array}$ \\
\hline Reference 15 & $\begin{array}{l}\text { Very disappointed about this ad. Â It is totally against Google's policies, yet } \\
\text { they make it sound OK. Â I think this ad should be shut down as false } \\
\text { advertisement. }\end{array}$ \\
\hline Reference 16 & $\begin{array}{l}\text { This ad proves why email is important, and should never be lost in the wealth of } \\
\text { online resources. }\end{array}$ \\
\hline Reference 17 & $\begin{array}{l}\text { I want to ask: If all google's services are closed to children, WHY it even allows } \\
\text { them to use apps for education? Just bar them from using them too. }\end{array}$ \\
\hline \multicolumn{2}{|c|}{$\begin{array}{l}\text { Internals } \mid 105.05 .17 \text { Dear Sophie - Data Collection - Oldest } 100 \\
6 \text { references coded [6.00\% Coverage] }\end{array}$} \\
\hline Reference & Comment \\
\hline Reference 1 & $\begin{array}{l}\text { I just created accounts for my } 11 \text { week old twin daughters on my personal } \\
\text { domain (Google Apps). This is a great idea. }\end{array}$ \\
\hline
\end{tabular}


Table D4 (continued)

\begin{tabular}{|l|l|}
\hline Reference & Comment \\
\hline Reference 2 & $\begin{array}{l}\text { Now if there was just an easy way to export all emails with attachments into a } \\
\text { digital photo book. Someone make that, I'll only take 5\% of the company for } \\
\text { coming up with the idea :) }\end{array}$ \\
\hline Reference 3 & @BlackTeaBag No problem. Gmail filter - done. \\
\hline Reference 4 & $\begin{array}{l}\text { anyone know what that picasa plugin is they use? all the ones I've tried are } \\
\text { pretty bad }\end{array}$ \\
\hline Reference 5 & This is awssm ... can user create their own chrome experiences ... ?? \\
\hline Reference 6 & Yeah $\sim$ the web/internet doesn't just have to be for PkZ0rn \\
\hline
\end{tabular}

Table D5: Dear Sophie (2011) - 3.Other/3A.Foreign Languages

\begin{tabular}{|c|c|}
\hline \multicolumn{2}{|c|}{$\begin{array}{l}\text { Internals } \backslash \mid 05.05 .17 \text { Dear Sophie - Data Collection - Newest } 100 \\
3 \text { references coded [3.00\% Coverage] }\end{array}$} \\
\hline Reference & Comment \\
\hline Reference 1 & 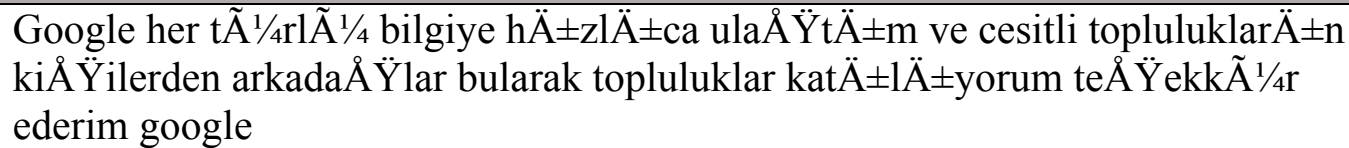 \\
\hline Reference 2 & Interessant zu sehen, wie Google an unserem Leben teilnimmt \\
\hline Reference 3 & $\begin{array}{l}\text { Nesacma hayat bu boyle birhayat olmaz olsun diyecem ama yaradanin } \\
\text { gucunegider herseye ragmen hayat cok gozel isyan etme doslar birgun onune } \\
\text { cikarir yaradan }\end{array}$ \\
\hline \multicolumn{2}{|c|}{$\begin{array}{l}\text { Internals } \mid 105.05 .17 \text { Dear Sophie - Data Collection - Oldest } 100 \\
2 \text { references coded [2.00\% Coverage] }\end{array}$} \\
\hline Reference & Comment \\
\hline Reference 1 & FODÃ STICO! \\
\hline Reference 2 & quero fazer isso com meus filhos algum dia :P \\
\hline
\end{tabular}

Table D6: Dear Sophie (2011) - 3.Other/3B.Non-Related Content

\begin{tabular}{|c|c|}
\hline \multicolumn{2}{|c|}{$\begin{array}{l}\text { Internals } \backslash \text { 05.05.17 Dear Sophie - Data Collection - Newest } 100 \\
11 \text { references coded [11.00\% Coverage] }\end{array}$} \\
\hline Reference & Comment \\
\hline Reference 1 & $\mathrm{Hi}$ \\
\hline Reference 2 & $\begin{array}{l}\text { Just realised that "Daniel Lee" is also Tablo's name. Totally something he would } \\
\text { do for Haru :3 }\end{array}$ \\
\hline Reference 3 & y \\
\hline Reference 4 & tq from malaysia \\
\hline Reference 5 & Happy Mother's Day too \\
\hline Reference 6 & Miki \\
\hline Reference 7 & hi! \\
\hline
\end{tabular}


Table D6 (continued)

\begin{tabular}{|l|l|}
\hline Reference & Comment \\
\hline Reference 8 & van \\
\hline Reference 9 & Bello \\
\hline Reference 10 & Terra Dimiourgos how is this false ? \\
\hline Reference 11 & Rob Johnston \\
\hline $\begin{array}{l}\text { Internals } \backslash \mathbf{0 5 . 0 5 . 1 7} \text { Dear Sophie - Data Collection - Newest 100 } \\
\text { 3 references coded [3.00\% Coverage] }\end{array}$ \\
\hline Reference & Comment \\
\hline Reference 1 & $\begin{array}{l}\text { @ shamiradnan Actually no one is forcing you to use Google services } \\
\text { anything else... }\end{array}$ \\
\hline Reference 2 & $\begin{array}{l}\text { @prashanthaku click the arrow pointing down next to the add to button } \\
\text { and it chould be the first choice that pops up. }\end{array}$ \\
\hline Reference 3 & aw first again \\
\hline
\end{tabular}

Table D7: Dear Sophie (2011) - 3.Other/3C.Non-Legible Spam

\begin{tabular}{|c|c|}
\hline \multicolumn{2}{|c|}{$\begin{array}{l}\text { Internals } \backslash 05.05 .17 \text { Dear Sophie - Data Collection - Newest } 100 \\
7 \text { references coded }[7.00 \% \text { Coverage] }\end{array}$} \\
\hline Reference 1 & gdfsu GT uegehfeye in 3+\#+@6\#:'* \\
\hline Reference 2 & 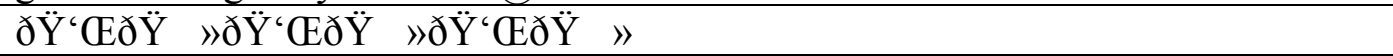 \\
\hline Reference 3 & 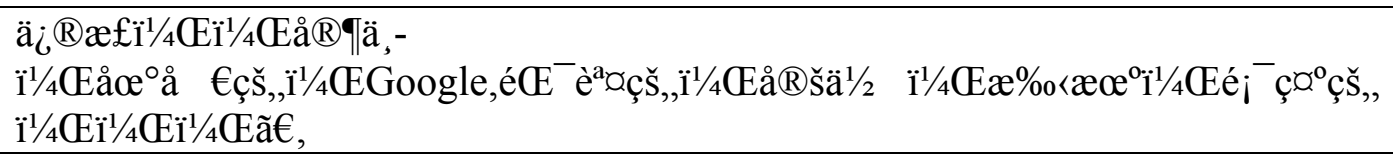 \\
\hline Reference 4 & cdsfaryyyuuuyruytg \\
\hline Reference 5 & 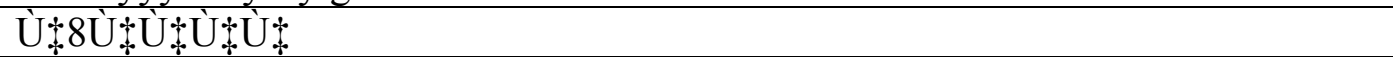 \\
\hline Reference 6 & 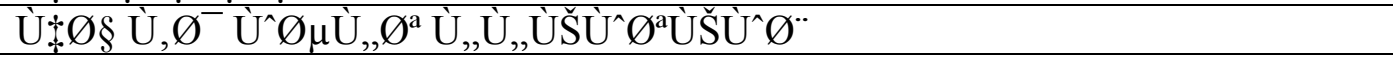 \\
\hline Reference 7 & 123456 \\
\hline
\end{tabular}




\section{Appendix E: Part I: Comparative Analysis Your Chrome, Everywhere (2012) Data Set}

The following Tables E1, E2, E3, E4, E5, E6, and E7 in Appendix E provide summaries of the data collected for Your Chrome, Everywhere (2012), as coded in NVivo.

Table E1: Your Chrome, Everywhere (2012) - 1.Reactional/1A.Positive Responses

\begin{tabular}{|c|c|}
\hline \multicolumn{2}{|c|}{$\begin{array}{l}\text { Internals } \backslash \mathbf{0 5 . 0 5 . 1 7} \text { Your Chrome, Everywhere - Data Collection - Newest } 100 \\
21 \text { references coded }[21.00 \% \text { Coverage] }\end{array}$} \\
\hline Reference & Comment \\
\hline Reference 1 & Hi dad :) \\
\hline Reference 2 & Love Google! They are the innovators. \\
\hline Reference 3 & All so nice thex \\
\hline Reference 4 & Google knows whats up! \\
\hline Reference 5 & I'm so trying that beatbox \\
\hline Reference 6 & nice! \\
\hline Reference 7 & Great \\
\hline Reference 8 & Awesome \\
\hline Reference 9 & super cool! \\
\hline Reference 10 & Ha ha Hi dog \\
\hline Reference 11 & Google knows how to make videos. \\
\hline Reference 12 & Google can put his seed in my daughter's belly \\
\hline Reference 13 & Google's commercials are THE BEST!! \\
\hline Reference 14 & best commercial ever!!! \\
\hline Reference 15 & Coool \\
\hline Reference 16 & $\begin{array}{l}\text { I freakin love this commercial. The whole sounds coming together is awesome! } \\
\text { They're just showing that Chrome is now available on the iPhone }\end{array}$ \\
\hline Reference 17 & Nice \\
\hline Reference 18 & Hi Dog! \\
\hline Reference 19 & Nice \\
\hline Reference 20 & $\begin{array}{l}\text { Making this my default browser in my iphone :) been looking forward to having } \\
\text { this app since } 2009\end{array}$ \\
\hline Reference 21 & this is great. i try it in google translate and its beatbox. \\
\hline \multicolumn{2}{|c|}{$\begin{array}{l}\text { Internals } \backslash \text { 05.05.17 Your Chrome, Everywhere - Data Collection - Oldest } 100 \\
31 \text { references coded [31.00\% Coverage] }\end{array}$} \\
\hline Reference & Comment \\
\hline Reference 1 & Pretty nice jam \\
\hline Reference 2 & $\begin{array}{l}\text { i love how they don't even mention the iphone by name - they just say "and now } \\
\text { even here". brilliant. }\end{array}$ \\
\hline
\end{tabular}


Table E1 (continued)

\begin{tabular}{|c|c|}
\hline Reference & Comment \\
\hline Reference 3 & $\begin{array}{l}\text { there is no war between apple and googleâ } €_{\mid}^{\prime} \text { google not releasing their app on } \\
\text { IOS ?? must be foolish, cos its the number } 1 \text { market, with no fragmentation, the } \\
\text { proff is that chrome on android is only for the newest smartphones, and a beta, } \\
\text { on IOS it works great, and compatible with all devices starting at firmware } \\
4.2 \text { â } €_{\mid}^{\prime} \text {. lol } \\
\text { and chekc the googleplex video's, they all have macs, and love appleâ } €_{\mid}^{\prime} \text {.as apple } \\
\text { love google too at the end. }\end{array}$ \\
\hline Reference 4 & $\begin{array}{l}\text { Apple letting it through is surprising, Google already has plenty of apps on the } \\
\text { App store. }\end{array}$ \\
\hline Reference 5 & Bravo,google is simply the best \\
\hline Reference 6 & $\begin{array}{l}\text { Don't know what is more surprising. } \\
\text { Google making Chrome for iOS or Apple actually letting it through censorship } \\
\text { in the first place. }\end{array}$ \\
\hline Reference 7 & beautiful video :) \\
\hline Reference 8 & $\begin{array}{l}\text { Same here, I love it } \\
\text { Just go to safari and type google.com/chrome/mobile. that's how I got it. }\end{array}$ \\
\hline Reference 9 & XD funny \\
\hline Reference 10 & $\begin{array}{l}\text { It's not the only owner, but you seem to have missed my point. It's a smart } \\
\text { move actually, to allow Apple users to use Chrome. That way they'll be exposed } \\
\text { to Google's products, and might make a switch to Android for their next phone. }\end{array}$ \\
\hline Reference 11 & Because Android is dead... :P \\
\hline Reference 12 & AWESOME GOOGLE CHROME! \\
\hline Reference 13 & $\begin{array}{l}\text { ITS A IPHONE } 5 ? \text { SEE SCREEN } \\
\text { SECOND } 52\end{array}$ \\
\hline Reference 14 & $\begin{array}{l}\text { LOLOLOLOLOLOLOLOLOLOLOLOLOLOLOLOLOLOLOLOLOLOLOLO } \\
\text { LOLOLOLOLOLOLOL } \\
\text { OLOLOLOL } \\
\text { V } \\
\text { E } \\
\text { IPHONE :) }\end{array}$ \\
\hline Reference 15 & LOLOL \\
\hline Reference 16 & $\begin{array}{l}\text { they're just giving apple a little love tap } \\
\text { hah. your funny } \\
\text { i can't le find }\end{array}$ \\
\hline Reference 17 & Finally for IOS!:D \\
\hline Reference 18 & $\begin{array}{l}\text { Wow this is gonna be cool!!! } \\
\text { It's not out yet, somewhere today }\end{array}$ \\
\hline Reference 19 & Google really did live up to its motto! \\
\hline Reference 20 & Now I love chrome \\
\hline Reference 21 & I have no use for this browser but man that ad was great \\
\hline Reference 22 & Haha I love that weird song! \\
\hline
\end{tabular}


Table E1 (continued)

\begin{tabular}{|l|l|}
\hline Reference & Comment \\
\hline Reference 23 & $\begin{array}{l}\text { Haha! Google is about bringing information and the joy of communication to } \\
\text { EVERYONE, EVERYWHERE, ALL THE TIME. It's not a business worried } \\
\text { about competitors. It's not about Android or iOS. }\end{array}$ \\
\hline Reference 24 & Chrome. Sex. Chrome. Finally, Forgetting about Safari. Thanks Google :) \\
\hline Reference 25 & CHROME FOR IPHONE!!!! YES!!!!!! \\
\hline Reference 26 & Chrome FTW \\
\hline Reference 27 & Cool video! :) \\
\hline Reference 28 & Chrome for iOS?! I'll have to check this out. \\
\hline Reference 29 & great idea \\
\hline Reference 30 & Thanks Google! \\
\hline Reference 31 & FINALLY!! I can get rid of safari on my iPod! \\
\hline
\end{tabular}

Table E2: Your Chrome, Everywhere (2012) - 1.Reactional/1B.Negative Responses

\begin{tabular}{|c|c|}
\hline \multicolumn{2}{|c|}{$\begin{array}{l}\text { Internals } \backslash \mathbf{0 5 . 0 5 . 1 7} \text { Your Chrome, Everywhere - Data Collection - Newest } 100 \\
8 \text { references coded [8.00\% Coverage] }\end{array}$} \\
\hline Reference & Comment \\
\hline Reference 1 & Chrome for Symbian please :( \\
\hline Reference 2 & The dislike's from Mozilla Firefox :D \\
\hline Reference 3 & $\begin{array}{l}\text { I emulated the song on technitone, but it never can match the one in this } \\
\text { video...: ( }\end{array}$ \\
\hline Reference 4 & ANNOYING commercial!! \\
\hline Reference 5 & $\begin{array}{l}\text { I see this commercial EVERYWHERE and it annoys the living heck out of me... } \\
\text { PLEASE LET IT STOP!!!!!! }\end{array}$ \\
\hline Reference 6 & $\begin{array}{l}\text { listen! not lisent! } \\
0: 19 \text { are you a troll, google? } \\
\text { LOLZ. }\end{array}$ \\
\hline Reference 7 & My Chrome everywhere, except my Android device.Yeah, that's funny... \\
\hline Reference 8 & $\begin{array}{l}\text { "and now even }>>\text { here }<<\text { " hahaha one cannot but love how they refuse to name } \\
\text { it :) }\end{array}$ \\
\hline \multicolumn{2}{|c|}{$\begin{array}{l}\text { Internals } \| \text { 05.05.17 Your Chrome, Everywhere - Data Collection - Oldest } 100 \\
7 \text { references coded [7.00\% Coverage] }\end{array}$} \\
\hline Reference & Comment \\
\hline Reference 1 & Correction: You can take it anywhere but my shitty Windows Phone \\
\hline Reference 2 & wtf with iPhone screen? \\
\hline Reference 3 & Thumbs up if you thought it is for Android. :| \\
\hline Reference 4 & fuck $u$ the ad sooing a ios platform it is a fack \\
\hline
\end{tabular}


Table E2 (continued)

\begin{tabular}{|l|l|}
\hline Reference & Comment \\
\hline Reference 5 & $\begin{array}{l}\text { As much as I believe that everyone should be able to experience chrome for } \\
\text { mobile, I'm a little bitter that google has decided to put it on iOS. Chrome isn't } \\
\text { one of the reasons I'm on android, but it's a nice distinguishing GOOGLE } \\
\text { feature. }\end{array}$ \\
\hline Reference 6 & dis's like google doesn't want Android to succeed.. \\
\hline Reference 7 & $\begin{array}{l}\text { So Google can release Chrome for IOS But they can release a fucking version } \\
\text { for Gingerbread... }\end{array}$ \\
\hline
\end{tabular}

Table E3: Your Chrome, Everywhere (2012) - 1.Reactional/1C.Neutral Responses

\begin{tabular}{|c|c|}
\hline \multicolumn{2}{|c|}{$\begin{array}{l}\text { Internals } \backslash \mathbf{0 5 . 0 5 . 1 7} \text { Your Chrome, Everywhere - Data Collection - Newest } 100 \\
17 \text { references coded }[17.00 \% \text { Coverage] }\end{array}$} \\
\hline Reference & Comment \\
\hline Reference 1 & Hi dog! \\
\hline Reference 2 & $\begin{array}{l}\text { Is it "Hi, dog" or "Hi, dad"? I read the transcription but it's just weird for your } \\
\text { daughter to say "Hi, dog" when she sees you on the phone }\end{array}$ \\
\hline Reference 3 & This commercial was made to demonstrate Chrome for iOS. \\
\hline Reference 4 & My Google Chrome On the World. \\
\hline Reference 5 & $\begin{array}{l}\text { because when he says "and now even here" hes referring to the fact that chrome } \\
\text { is now available on iOS because it hasn't always been where as it was on } \\
\text { android since release. } \\
\text { I don't need saving by a pretend dead man in a dress thanks. }\end{array}$ \\
\hline Reference 6 & Did any 1 realize that was a fake iPhone. \\
\hline Reference 7 & $\begin{array}{l}\text { was he using a iphone ? would he not use a galaxy seeing how Google helped } \\
\text { make that }\end{array}$ \\
\hline Reference 8 & Everyone running GOOGLE is a GOLDBERG. \\
\hline Reference 9 & i was expecting the galaxy nexus to appear after the tablet. \\
\hline Reference 10 & anyone noticed they used an iphone lol \\
\hline Reference 11 & $0: 46$ Its the code! \\
\hline Reference 12 & It said it was remixed game music on the subtitles.Anyone know what the it is? \\
\hline Reference 13 & I don't get it? \\
\hline Reference 14 & Wait. Why an iPhone? Not a Nexus? \\
\hline Reference 15 & what does it means \\
\hline Reference 16 & $\begin{array}{l}\text { Were we watching the same video? 0:27 Im pretty sure that that is chrome on } \\
\text { android }\end{array}$ \\
\hline Reference 17 & their kinda skipping those loading times! haha \\
\hline
\end{tabular}


Table E3 (continued)

\begin{tabular}{|c|c|}
\hline \multicolumn{2}{|c|}{$\begin{array}{l}\text { Internals } \backslash \mathbf{0 5 . 0 5 . 1 7} \text { Your Chrome, Everywhere - Data Collection - Oldest } 100 \\
13 \text { references coded [13.00\% Coverage] }\end{array}$} \\
\hline Reference & Comment \\
\hline Reference 1 & But why is there an iPhone when Google has ardour \\
\hline Reference 2 & I think their trying to say their browser now works with iOS devices.. :) \\
\hline Reference 3 & Google and Apple have always been competitive buddies \\
\hline Reference 4 & $0: 43$...even_here_.:D \\
\hline Reference 5 & WHAT IS THE SONG!!! ALSO ANDROID FTW \\
\hline Reference 6 & Is it out on the app store now? Cause $\mathrm{i}$ cant find it \\
\hline Reference 7 & The simulation on the screen is out of sync with the guy's finger. \\
\hline Reference 8 & I love how they say it "here",.... \\
\hline Reference 9 & That was one cool remix \\
\hline Reference 10 & $\begin{array}{l}\text { If this is an ad for Chrome on Android (which it is), why are they using an } \\
\text { iPhone? }\end{array}$ \\
\hline Reference 11 & You fucked up with the ios \\
\hline Reference 12 & Your botnet, everywhere \\
\hline Reference 13 & $\begin{array}{l}\text { I'm currently not seeing this for iOS in the App Store... } \\
\text { is this only available through non-App-Store means? }\end{array}$ \\
\hline
\end{tabular}

Table E4: Your Chrome, Everywhere (2012) - 2. Non-Reactional

\begin{tabular}{|c|c|}
\hline \multicolumn{2}{|c|}{$\begin{array}{l}\text { Internals } \backslash \mathbf{0 5 . 0 5 . 1 7} \text { Your Chrome, Everywhere - Data Collection - Newest } 100 \\
21 \text { references coded }[21.00 \% \text { Coverage] }\end{array}$} \\
\hline Reference & Comment \\
\hline Reference 1 & Chrome for android add suport desktop plugins \\
\hline Reference 2 & $\begin{array}{l}\text { I want to know why Chrome Lock } \\
\text { is one of the browsers that hangs over my computer }\end{array}$ \\
\hline Reference 3 & $\begin{array}{l}\text { TECHNITONE is now offline... } \\
:(\end{array}$ \\
\hline Reference 4 & They missed something.. "Never coming to Windows Phone." Google, why. \\
\hline Reference 5 & can't open technitone on Iphone??? \\
\hline Reference 6 & why iphone? \\
\hline Reference 7 & but... why iphone ? and galaxy nexus? \\
\hline Reference 8 & $\begin{array}{l}\text { Last time I checked, my phone is running Gingerbread. } \\
\text { And that's basically the reason why I wondered about your original point ... } 3 \\
\text { months ago. O_o }\end{array}$ \\
\hline
\end{tabular}


Table E4 (continued)

\begin{tabular}{|c|c|}
\hline Reference & Comment \\
\hline Reference 9 & Its the most amazing browser yet \\
\hline Reference 10 & $\begin{array}{l}\text { the android browser is fine as it is... Chrome takes too much ram/space.. } \\
\text { seriously the only useful feature is sync... otherwise they're the same }\end{array}$ \\
\hline Reference 11 & Two words. Internet connection. \\
\hline Reference 12 & $\begin{array}{l}\text { that's not google's fault though; apple doesn't allow 3rd party libraries for web } \\
\text { rendering, so they have to use the same webview that apps like facebook use to } \\
\text { display webpages. apple doesn't use their nitro js engine (which they use in } \\
\text { safari) in webview, so chrome, and any other browser on ios, is slower than } \\
\text { safari. }\end{array}$ \\
\hline Reference 13 & $\begin{array}{l}\text { Stock Android Browser still feels a little more snappy and is faster with rending } \\
\text { when you do a lot of zooming and scrolling. }\end{array}$ \\
\hline Reference 14 & $\begin{array}{l}\text { Please include an update to have the google translate within the mobile } \\
\text { browser!! Thanks!! }\end{array}$ \\
\hline Reference 15 & Too bad Chrome for iOS is laggy as shit. \\
\hline Reference 16 & $\begin{array}{l}\text { 1. Go to Google Translate } \\
\text { 2. Type that (Or Copy/Paste if you want..) } \\
\text { 4. Click the speaker. It now says "Beatbox", insted of "lisent". } \\
\text { 5. Congratz. You can now hear Google Translate beatbox! }\end{array}$ \\
\hline Reference 17 & Flash comes with Chrome when you download it. \\
\hline Reference 18 & $\begin{array}{l}\text { will Chrome have flash player plug in? } \\
\text { when you download flash or chrome? o.O }\end{array}$ \\
\hline Reference 19 & $\begin{array}{l}\text { Nice to know chrome is taking over the world, but the video accuracy is way } \\
\text { way off :/ }\end{array}$ \\
\hline Reference 20 & It will work on any android device with ICS and up. Not on gingerbread though \\
\hline Reference 21 & the stock ICS browser is a lot more fluid. You can't even use flash on chrome \\
\hline \multicolumn{2}{|c|}{$\begin{array}{l}\text { Internals } \backslash \mathbf{0 5 . 0 5 . 1 7} \text { Your Chrome, Everywhere - Data Collection - Oldest } 100 \\
33 \text { references coded [33.00\% Coverage] }\end{array}$} \\
\hline Reference & Comment \\
\hline Reference 1 & Tab syncing won't work on my iPhone \\
\hline Reference 2 & $\begin{array}{l}\text { when i open i new tab on my upgraded google chrome i dont see "other devices" } \\
\text {, }\end{array}$ \\
\hline Reference 3 & it needs to be on atleast android 4.0 \\
\hline Reference 4 & $\begin{array}{l}\text { Just type in chrome and it should show up } \\
\text { To get Chrome for iPhone just type in Chrome and it should show up }\end{array}$ \\
\hline Reference 5 & so where can i get this in the market for android? \\
\hline Reference 6 & $\begin{array}{l}\text { well, because of nitro javascript engine, safari is still faster than chrome on ios } \\
\text { A }\end{array}$ \\
\hline Reference 7 & $\begin{array}{l}\text { It says it's been pulled from the store??? :( } \\
\text { "The item you tried to buy is no longer available" :(: }(\end{array}$ \\
\hline Reference 8 & $\begin{array}{l}\text { To get it, go to google.com/chrome/mobile in safari on your iPhone ;) thumps up } \\
\text { so everyone can see, it wasn't the easiest to figure out }\end{array}$ \\
\hline Reference 9 & $\begin{array}{l}\text { Haha, just like in Windows - you have to download the better browser from the } \\
\text { wrost. :) }\end{array}$ \\
\hline
\end{tabular}


Table E4 (continued)

\begin{tabular}{|c|c|}
\hline Reference & Comment \\
\hline Reference 10 & Chrome isn't showing up in the App Store for me. Anyone know why this is? \\
\hline Reference 11 & $\begin{array}{l}\text { Finally Chrome for iOS - THis is a day I have been waiting for ever since man } \\
\text { walked on the moon! }\end{array}$ \\
\hline Reference 12 & Go to link in description, there is a link to the app store page for chrome \\
\hline Reference 13 & I'm trying to search it in the Appstore but I can't find it. Where is it? \\
\hline Reference 14 & $\begin{array}{l}\text { Google chrome tab sync was here before apple even thougt using icloud tab } \\
\text { sync!! }\end{array}$ \\
\hline Reference 15 & *Replacing the Safari in the dock to Chrome* \\
\hline Reference 16 & Meh Safari is still the best mobile browser \\
\hline Reference 17 & Well not everywere. not on my android fone :( no ics no chrome :-( \\
\hline Reference 18 & They should release chrome for Gingerbread devices first. \\
\hline Reference 19 & Cant wait to try it out on iphone \\
\hline Reference 20 & still no privacy options \\
\hline Reference 21 & They just announced Chrome for iOS today and it will be out later today. \\
\hline Reference 22 & i cant find it on the app store!!!! \\
\hline Reference 23 & now they have Chrome on IOS. \\
\hline Reference 24 & $\begin{array}{l}\text { Wow, youtube loads in } 0.5 \text { seconds without even touching the screen. What } \\
\text { witchcraft is this!!!???!! }\end{array}$ \\
\hline Reference 25 & $\begin{array}{l}\text { It's weird that nobody has ever asked yet for the Dog and Kid video. Here it is } \\
\text { anyway /watch?v=DlT4rLrvPS4 }\end{array}$ \\
\hline Reference 26 & Chrome on iPAD!! CAN I DELETE SAFARI ON IOS????? \\
\hline Reference 27 & @antoinecampbell Please put this on iPad as well! \\
\hline Reference 28 & Where can I get Chrome for my iPhone? \\
\hline Reference 29 & $\begin{array}{l}\text { Google develops and owns Android though. } \\
\text { Welcome to the future, iOS users. } 1 \text { step at a time guys. }\end{array}$ \\
\hline Reference 30 & i love it too open porn at one pc with many tab and open in tab in room lol \\
\hline Reference 31 & Where can I get Chrome on my iPod Touch? :D \\
\hline Reference 32 & $\begin{array}{l}\text { You can't get rid of it, in any other app links will open in Safari, since you can't } \\
\text { set other browsers as the default browser }\end{array}$ \\
\hline Reference 33 & beatbox doesn't work. \\
\hline
\end{tabular}

Table E5: Your Chrome, Everywhere (2012) - 3.Other/3A.Foreign Languages

Internals $\backslash$ 05.05.17 Your Chrome, Everywhere - Data Collection - Newest 100 2 references coded [2.00\% Coverage]

Reference $\quad$ Comment

Reference 1 Muy util

Reference 2 je na rive pas a installe google chrome icon 
Table E5 (continued)

\begin{tabular}{|c|c|}
\hline \multicolumn{2}{|c|}{$\begin{array}{l}\text { Internals } \backslash \mathbf{0 5 . 0 5 . 1 7} \text { Your Chrome, Everywhere - Data Collection - Oldest } 100 \\
5 \text { references coded }[5.00 \% \text { Coverage }]\end{array}$} \\
\hline Reference & Comment \\
\hline Reference 1 & Un video muy original \\
\hline Reference 2 & Beatbox...ME GUSTA \\
\hline Reference 3 & Ils ont Motorola et Android! Donc cela ne sera $\tilde{A}$ rien pour mettre sur iOS! \\
\hline Reference 4 & SerÃ $i$ gratis? \\
\hline Reference 5 & Muy bueno, felicitaciones ;) \\
\hline
\end{tabular}

Table E6: Your Chrome, Everywhere (2012) - 3. Other/3B. Non-Related Content

\begin{tabular}{|c|c|}
\hline \\
\hline \multicolumn{2}{|c|}{$\begin{array}{l}\text { Internals } \backslash \mathbf{0 5 . 0 5 . 1 7} \text { Your Chrome, Everywhere - Data Collection - Newest } 100 \\
27 \text { references coded [27.00\% Coverage] }\end{array}$} \\
\hline \multicolumn{2}{|l|}{ Reference 1} \\
\hline \multirow{2}{*}{$\begin{array}{l}\text { Reference } 2 \\
\text { Reference } 3\end{array}$} & because the iPhone holds a bigger market share. \\
\hline & $\begin{array}{l}\text { @TheMillman7 } \\
\text { @,vitababkin } 835\end{array}$ \\
\hline Reference 4 & $\begin{array}{l}\text { Free Dom in World ...same World is Life. Can Touch everytime } \\
\text { Teacher real... Have teach with Vedio ...good }\end{array}$ \\
\hline Reference 5 & $\begin{array}{l}\text { Each day is an opportunity to our lives, therefore, all the human race must live } \\
\text { the life as if he/she will die tomorrow. Let's emulate the life Jesus Christ lived } \\
\text { while on earth. }\end{array}$ \\
\hline Reference 6 & Which gets the best results? Saving? Or investing? :) \\
\hline Reference 7 & $\begin{array}{l}\text { "What no eye has seen, nor ear heard, nor the heart of man conceived, what God } \\
\text { has prepared for those who love him," }\end{array}$ \\
\hline Reference 8 & even here... lol \\
\hline Reference 9 & Its mystery guitar man!! \\
\hline Reference 10 & you missed out three? \\
\hline Reference 11 & $\begin{array}{l}\text { Hehehe. I never noticed the comment. Ahh well you're lucky if you have } \\
\text { gingerbread and it works for you. }\end{array}$ \\
\hline \multirow{2}{*}{$\begin{array}{l}\text { Reference } 12 \\
\text { Reference } 13\end{array}$} & You got Android 2.3. No. You have ICS, that's the point I'm making \\
\hline & I notice that $\sim \sim$ \\
\hline \multirow{2}{*}{$\begin{array}{l}\text { Reference } 14 \\
\text { Reference } 15\end{array}$} & Android for life! \\
\hline & brothers riedell voices..? \\
\hline Reference 16 & $\begin{array}{l}\text { Sorry. im SO sorry. Did it hurrrt you? Ooooh siht does this shti anoie yuo. Butt i } \\
\text { do'nt ca're. Yo'ud understanded me in dat' coment, rihgt? Sho STFU. }\end{array}$ \\
\hline \multirow{2}{*}{$\begin{array}{l}\text { Reference } 17 \\
\text { Reference } 18\end{array}$} & @)rand42Studios \\
\hline & $\begin{array}{l}\text { No. } \\
\text { Don't worry, i won't tell anyone. }\end{array}$ \\
\hline Reference 19 & Well....there is \\
\hline
\end{tabular}


Table E7 (continued)

\begin{tabular}{|c|c|}
\hline Reference & Comment \\
\hline Reference 2 & $\begin{array}{l}\text { kkkkkkkkkk pv zk bschk zpvzkpv bschk zk pv zk bschk zpvzkpv bschk zk } \\
\text { pv zk bschk zpvzkpv bschk zk pschk pv bschk bschk pv . pv zk bschk } \\
\text { zpvzkpv bschk zk pv zk bschk zpvzkpv bschk zk pv zk bschk zpvzkpv } \\
\text { bschk zk pschk pv pschk bschk pv . pv zk bschk zpvzkpv bschk zk pv zk } \\
\text { bschk zpvzkpv bschk zk pv zk bschk zpvzkpv bschk zk pv zk bschk } \\
\text { zpvzkpv bschk zk pv zk bschk zpvzkpv bschk zk pv . kkkkkkkkkk bschk } \\
\text { zk pv zk bschk zpvzkp bschk zk pv zk bschk zpvzkpv bschk zk pv zk } \\
\text { bschk zpvzkpv pschk zk pv zk } \\
\text {...bschk zpvzkpv bschk zk pv }\end{array}$ \\
\hline Reference 3 & 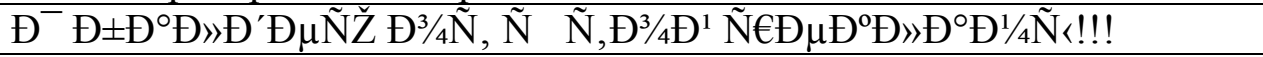 \\
\hline Reference 4 & hffghui \\
\hline \multicolumn{2}{|c|}{$\begin{array}{l}\text { Internals } \backslash \mathbf{0 5 . 0 5 . 1 7} \text { Your Chrome, Everywhere - Data Collection - Newest } 100 \\
2 \text { references coded [2.00\% Coverage] }\end{array}$} \\
\hline Reference & Comment \\
\hline Reference 1 & $* * *$ \\
\hline Reference 2 & 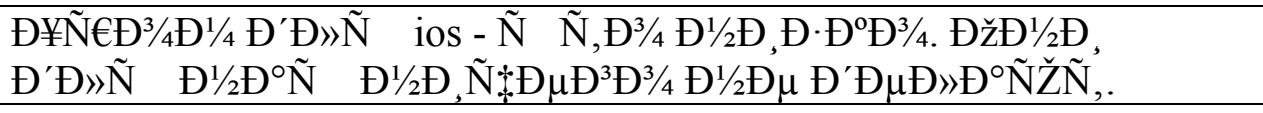 \\
\hline
\end{tabular}


Appendix F: Part II: Multimodal Analysis

Transcription Codebook

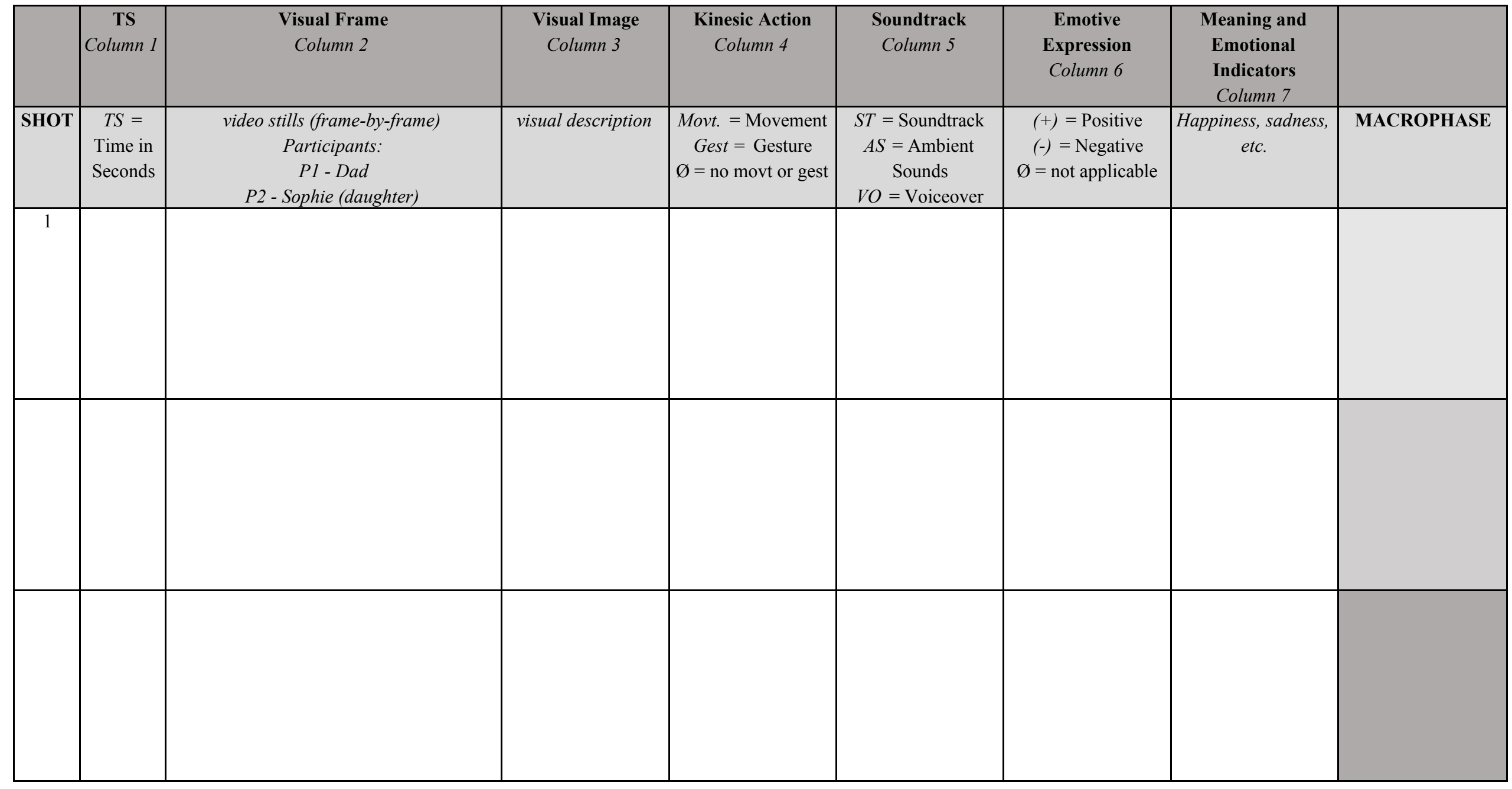


Appendix G: Part II: Multimodal Analysis

Transcription of Google's Dear Sophie (2011) Advertisement

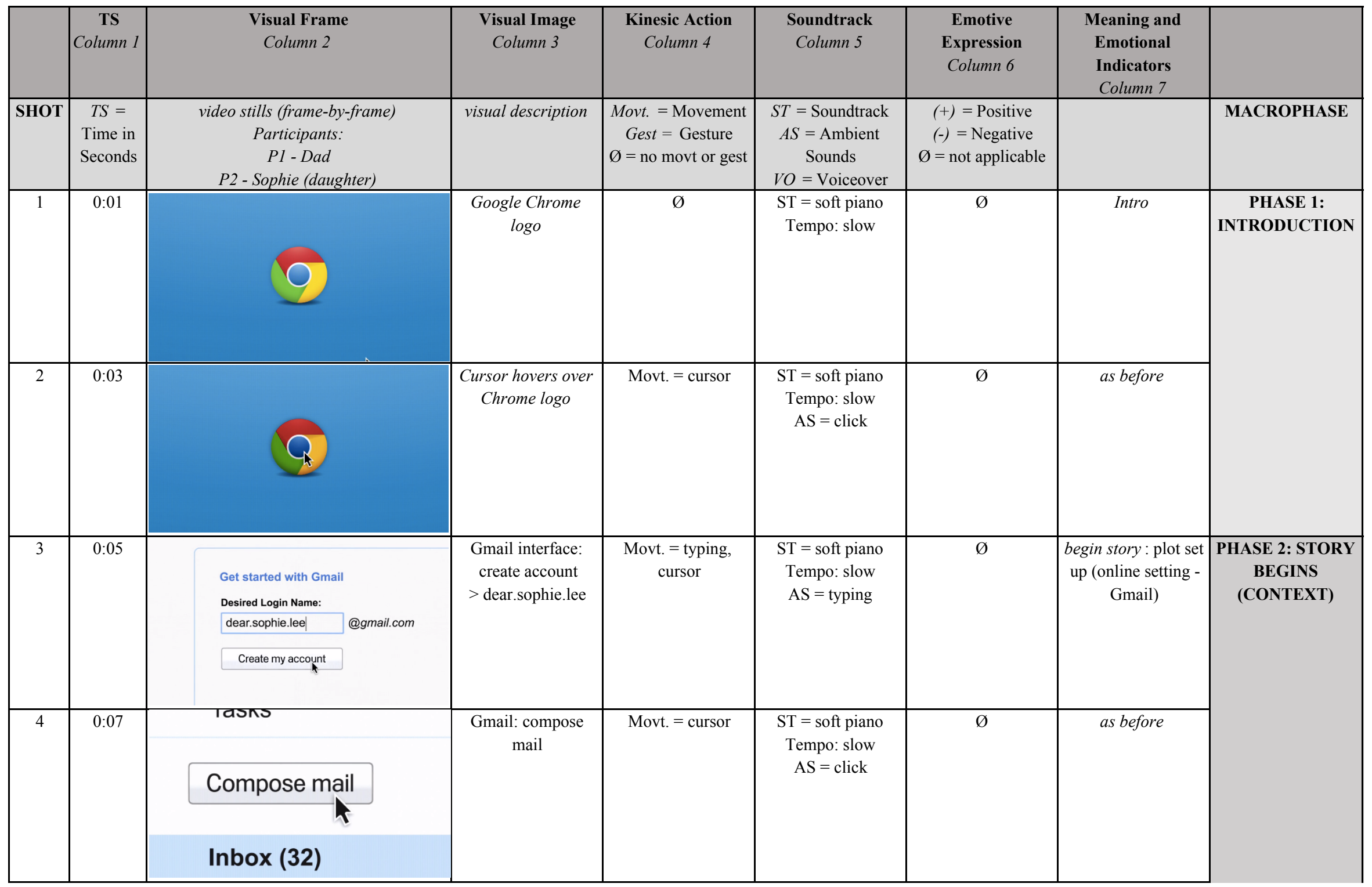




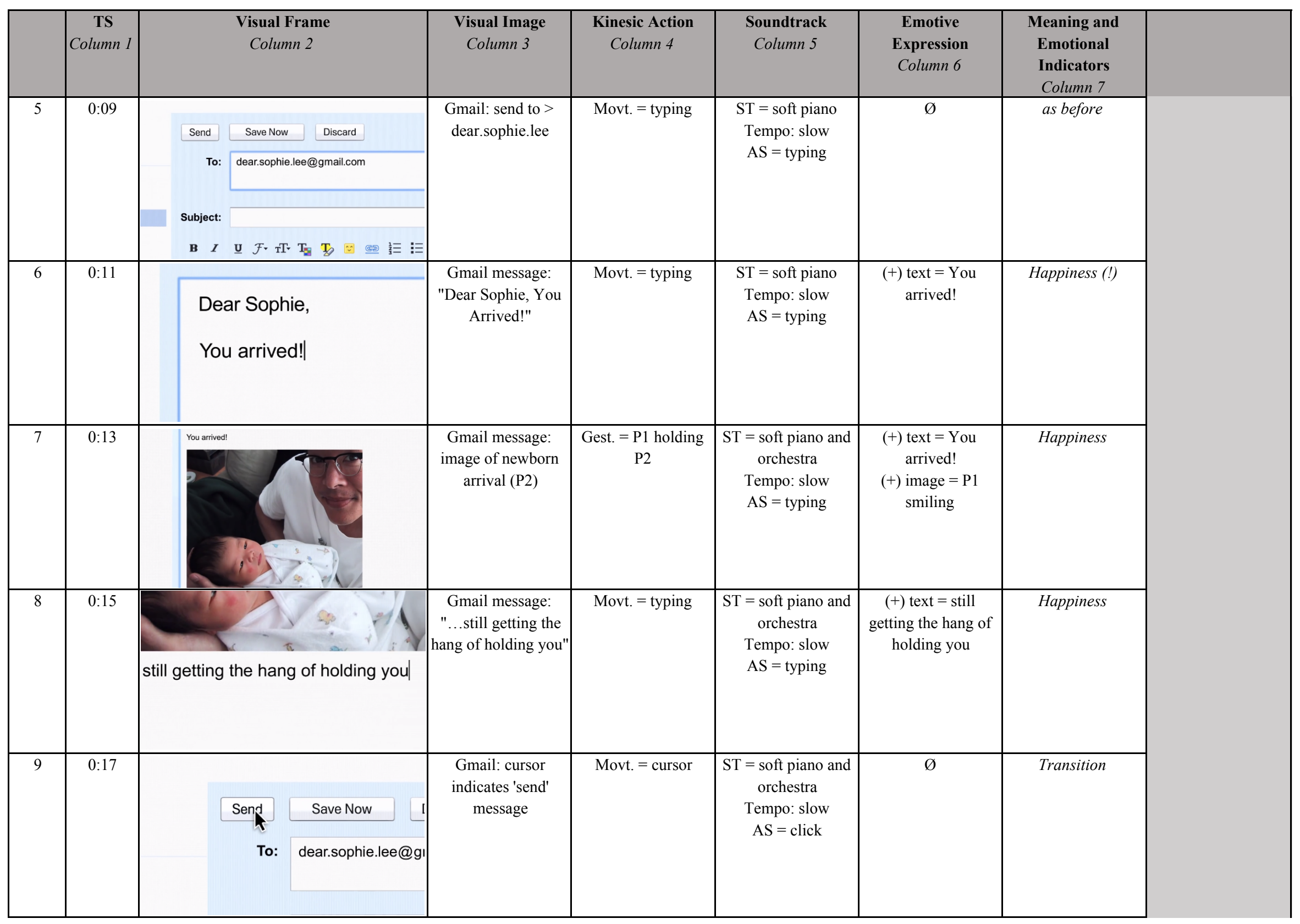




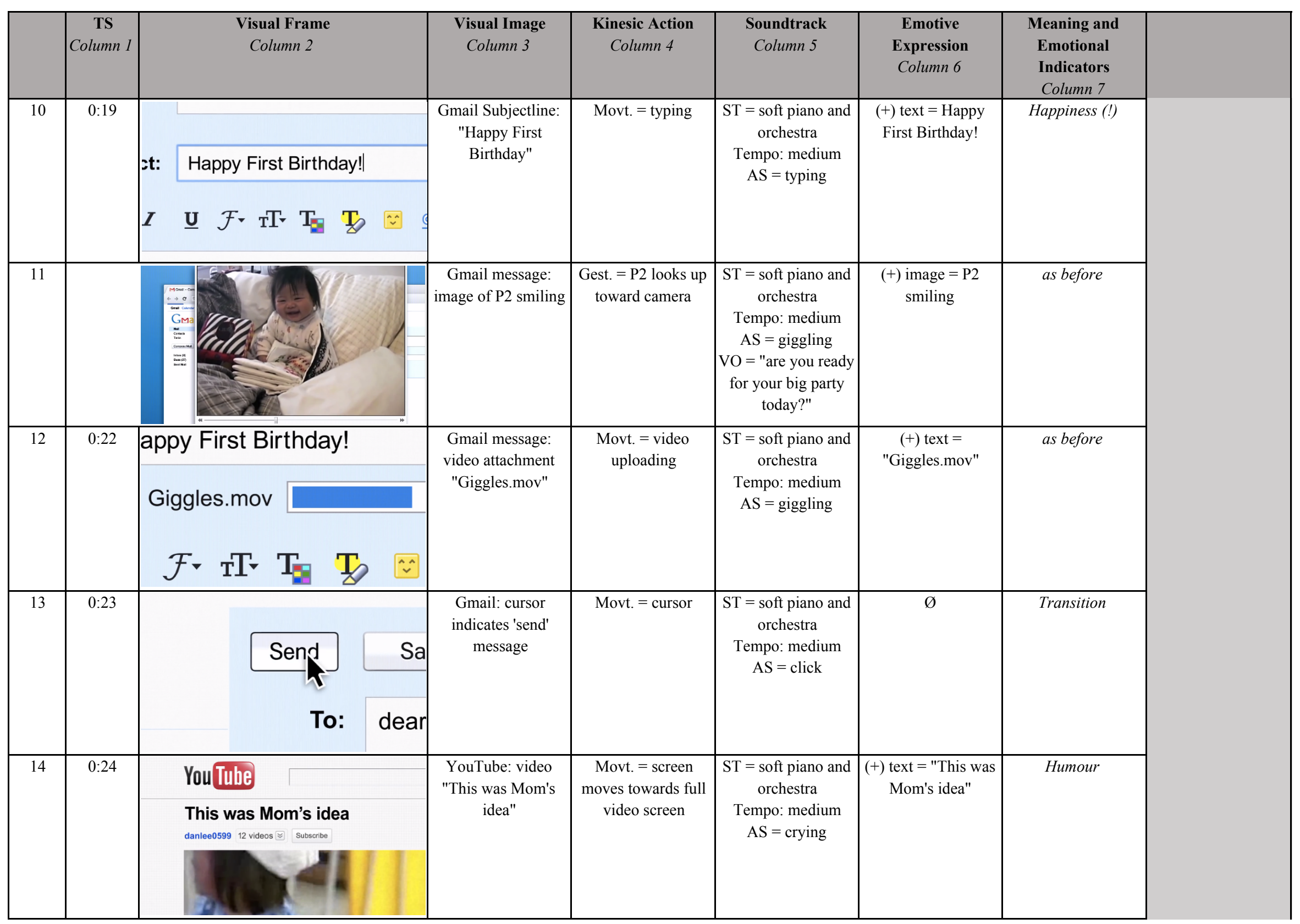




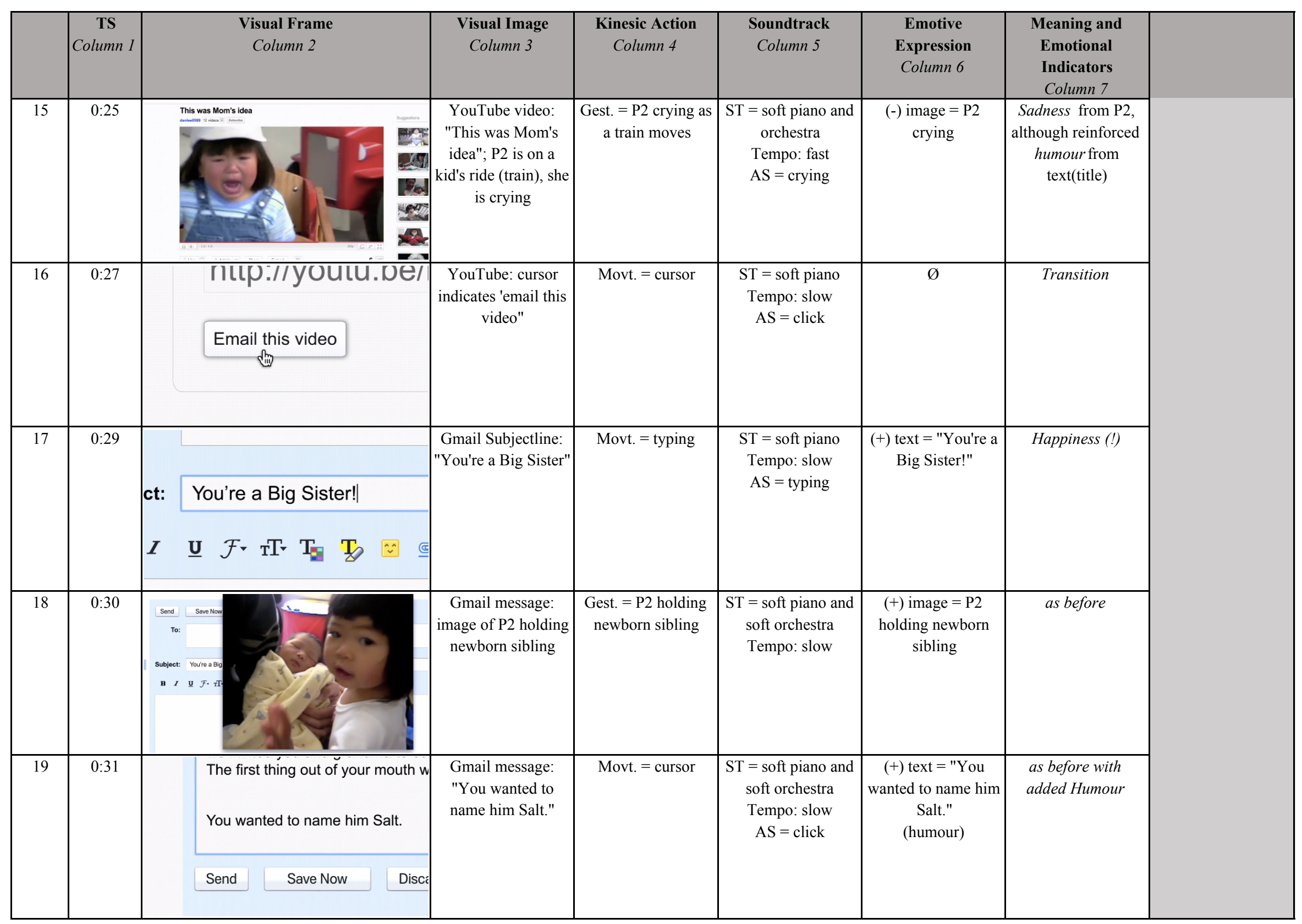




\begin{tabular}{|c|c|c|c|c|c|c|c|c|}
\hline & $\begin{array}{c}\text { TS } \\
\text { Column 1 }\end{array}$ & $\begin{array}{c}\text { Visual Frame } \\
\text { Column } 2\end{array}$ & $\begin{array}{c}\text { Visual Image } \\
\text { Column } 3\end{array}$ & $\begin{array}{l}\text { Kinesic Action } \\
\text { Column } 4\end{array}$ & $\begin{array}{l}\text { Soundtrack } \\
\text { Column } 5\end{array}$ & $\begin{array}{l}\text { Emotive } \\
\text { Expression } \\
\text { Column } 6\end{array}$ & $\begin{array}{l}\text { Meaning and } \\
\text { Emotional } \\
\text { Indicators } \\
\text { Column } 7\end{array}$ & \\
\hline \multirow[t]{2}{*}{20} & $0: 33$ & $L$ & $\begin{array}{l}\text { Gmail Subjectline: } \\
\text { "In the Hospital" }\end{array}$ & Movt. $=$ text appears & $\begin{array}{c}\mathrm{ST}=\text { soft piano and } \\
\text { soft orchestra }\end{array}$ & $\begin{array}{l}\text { (-) text }=\text { "In the } \\
\text { Hospital" }\end{array}$ & Suspense & $\begin{array}{l}\text { PHASE 3: } \\
\text { CONFLICT }\end{array}$ \\
\hline & & ct: In the Hospital & & & & & & \\
\hline 21 & $0: 34$ & $\begin{array}{l}\text { ice vveui iesuay aitei } \\
\text { ¡ a really bad fever.| }\end{array}$ & $\begin{array}{c}\text { Gmail message: "...a } \\
\text { really bad fever" }\end{array}$ & Movt. $=$ typing & $\begin{array}{c}\text { ST = soft piano and } \\
\text { soft orchestra } \\
\text { Tempo: slow } \\
\text { AS = typing }\end{array}$ & $\begin{array}{c}(-) \text { text }=\text { "... a really } \\
\text { bad fever." }\end{array}$ & Sadness, Suspense & \\
\hline 22 & $0: 36$ & $\begin{array}{l}\text { ivas a I eally wau IEver. I u III in yu } \\
\text { as parents. } \\
\text { ut it. We felt so helpless. }\end{array}$ & $\begin{array}{l}\text { Gmail message: "We } \\
\text { felt so helpless" }\end{array}$ & Movt. = typing & $\begin{array}{c}\text { ST = soft piano and } \\
\text { soft orchestra } \\
\text { Tempo: slow } \\
\text { AS = typing }\end{array}$ & $\begin{array}{c}(-) \text { text }=\text { "We felt so } \\
\text { helpless." }\end{array}$ & Sadness, Suspense & \\
\hline 23 & $0: 37$ & $\begin{array}{ll}\text { Love, } \\
\text { Dad }\end{array}$ & $\begin{array}{l}\text { Gmail message: } \\
\text { image of } \mathrm{P} 2 \text { smiling } \\
\text { in hospital bed with }\end{array}$ & $\begin{array}{l}\text { Gest. }=\text { P2 looks up } \\
\text { toward camera }\end{array}$ & $\begin{array}{c}\text { ST }=\text { soft piano and } \\
\text { orchestra } \\
\text { Tempo: medium }\end{array}$ & $\begin{array}{l}(+) \text { image }=\mathrm{P} 2 \\
\text { smiling }\end{array}$ & Happiness (relief) & \\
\hline 24 & $0: 39$ & F) & $\begin{array}{l}\text { YouTube video: "4th } \\
\text { Birthday"; P2 is } \\
\text { blowing out birthday } \\
\text { candles (brother in } \\
\text { the background) }\end{array}$ & $\begin{array}{l}\text { Gest. }=\text { P2 blowing } \\
\text { candles }\end{array}$ & $\begin{array}{c}\text { ST = soft piano and } \\
\text { orchestra } \\
\text { Tempo: medium } \\
\text { AS = blowing, } \\
\text { clapping } \\
\text { VO = "yay!" }\end{array}$ & $\begin{array}{l}(+) \text { text }=" 4 \text { th } \\
\text { Birhtday" } \\
(+) \text { image }=\mathrm{P} 2 \\
\text { blowing candles in } \\
\text { celebration }\end{array}$ & Happiness & $\begin{array}{l}\text { PHASE 4: } \\
\text { CLIMAX }\end{array}$ \\
\hline
\end{tabular}




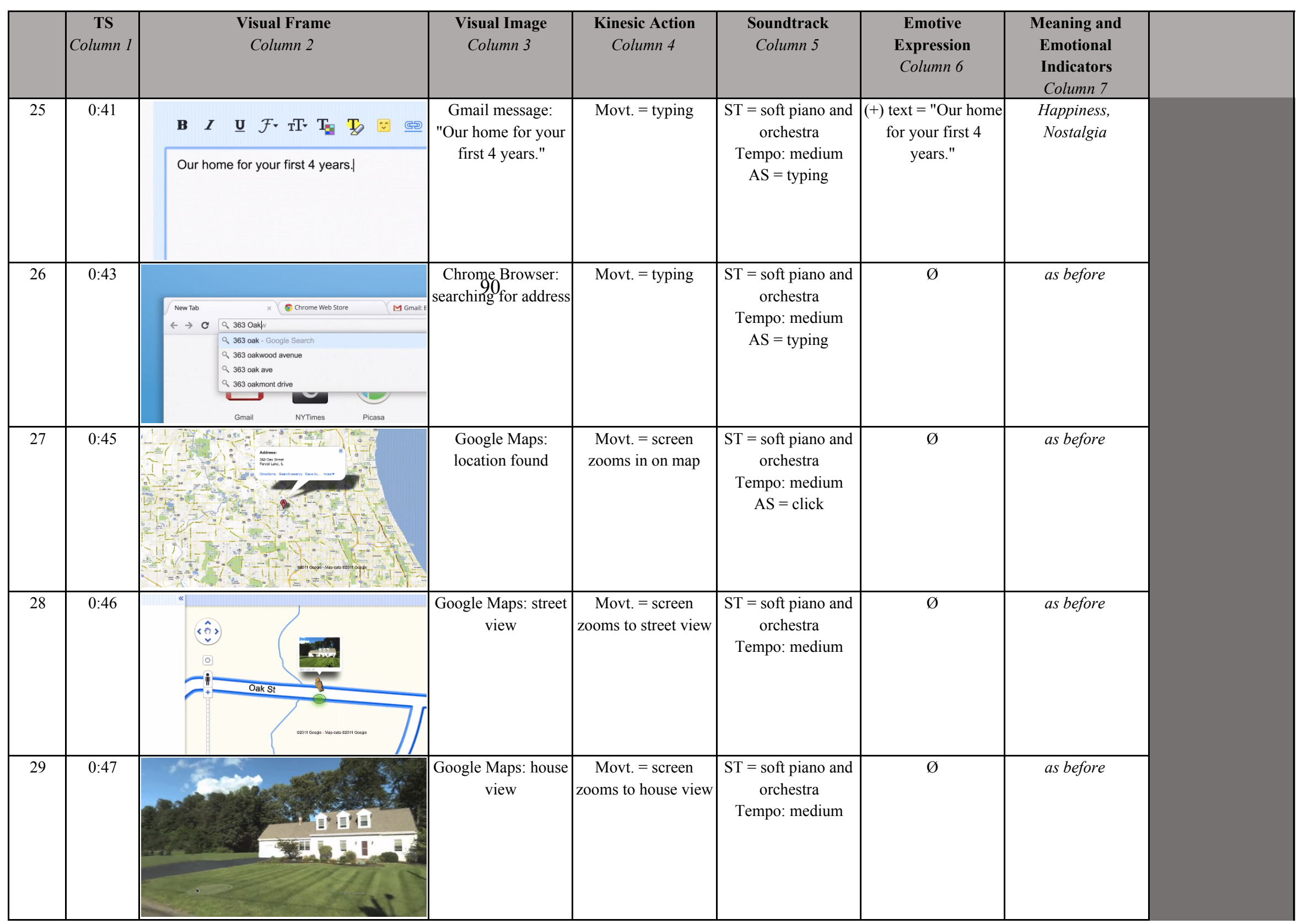




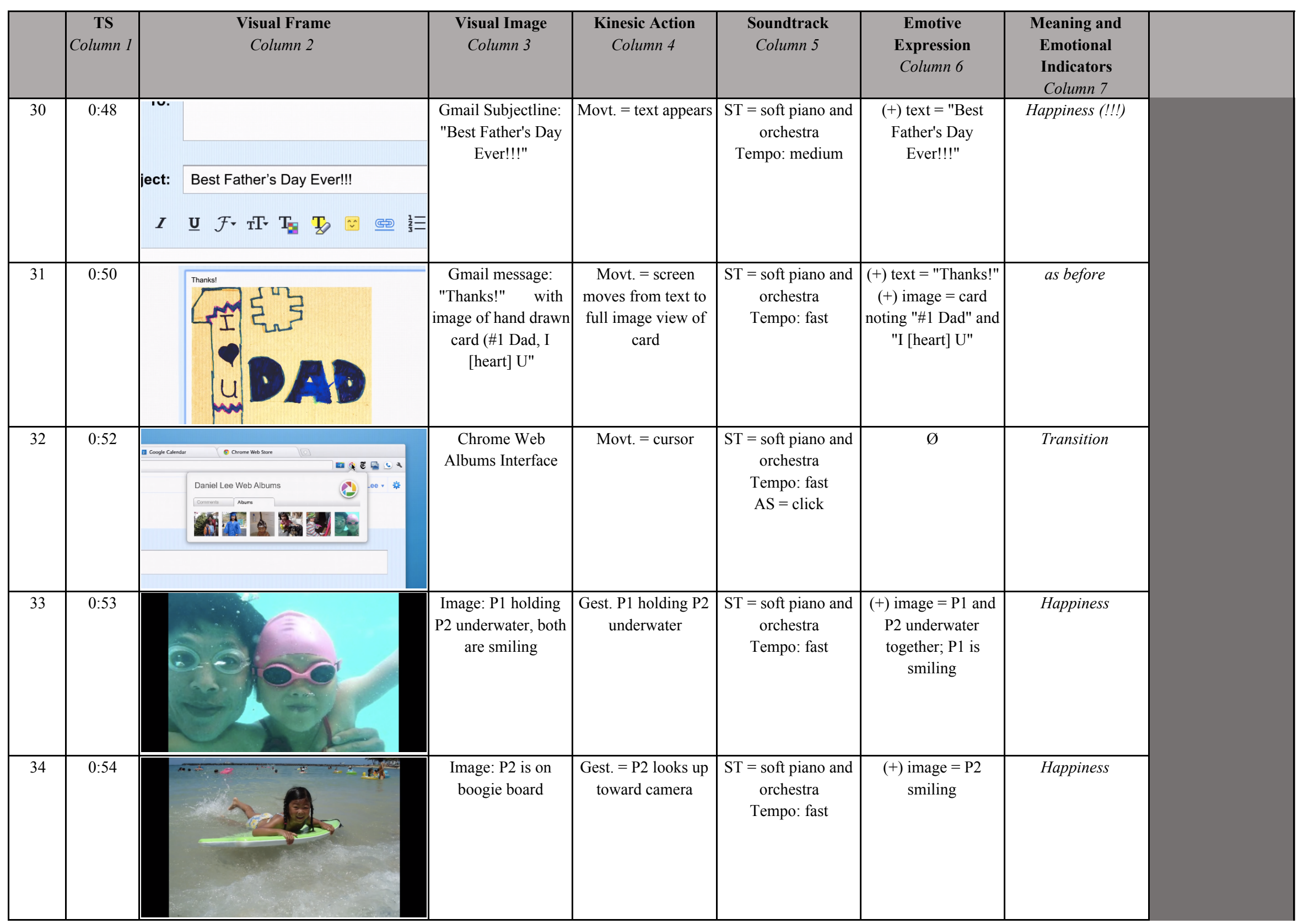




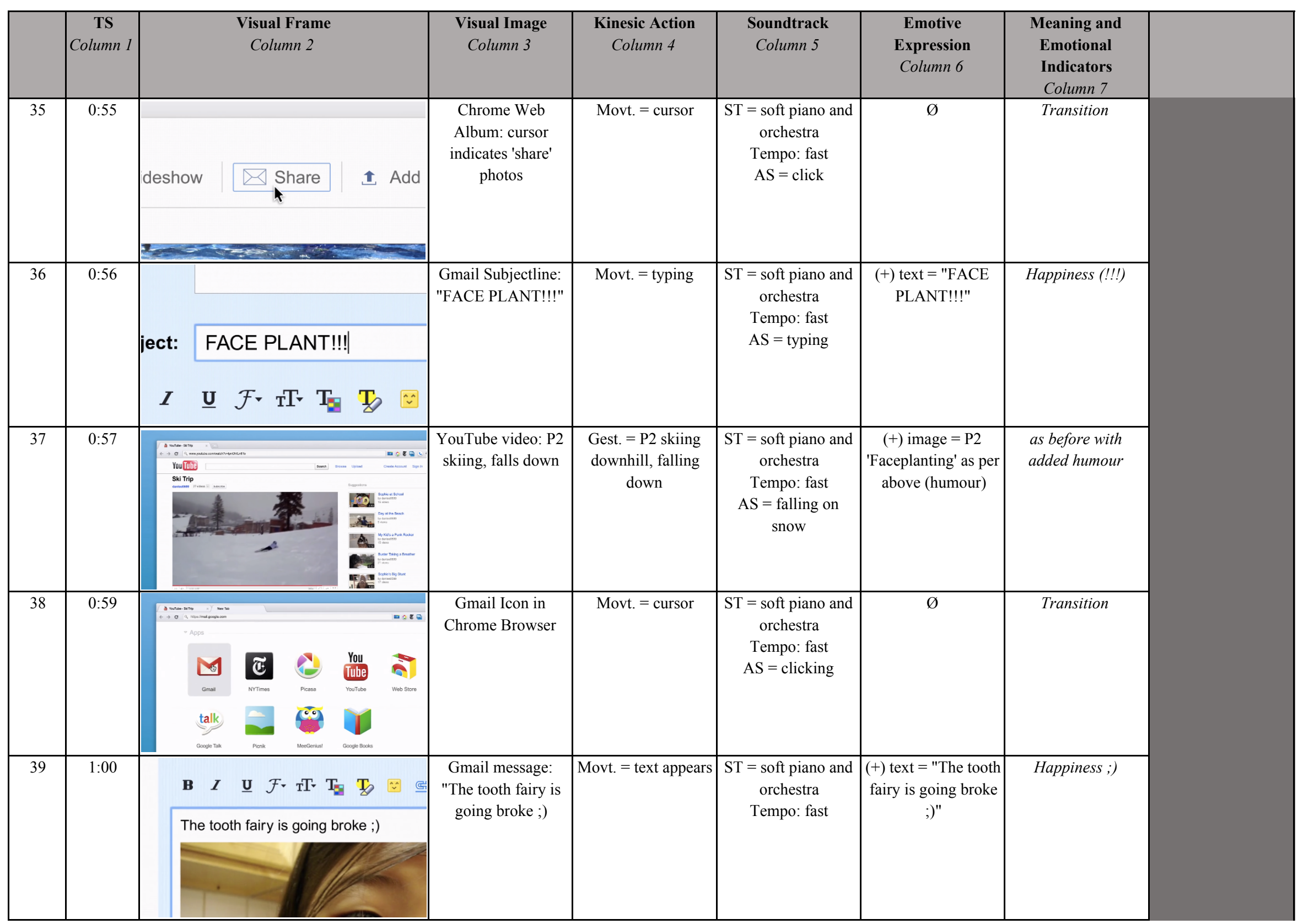




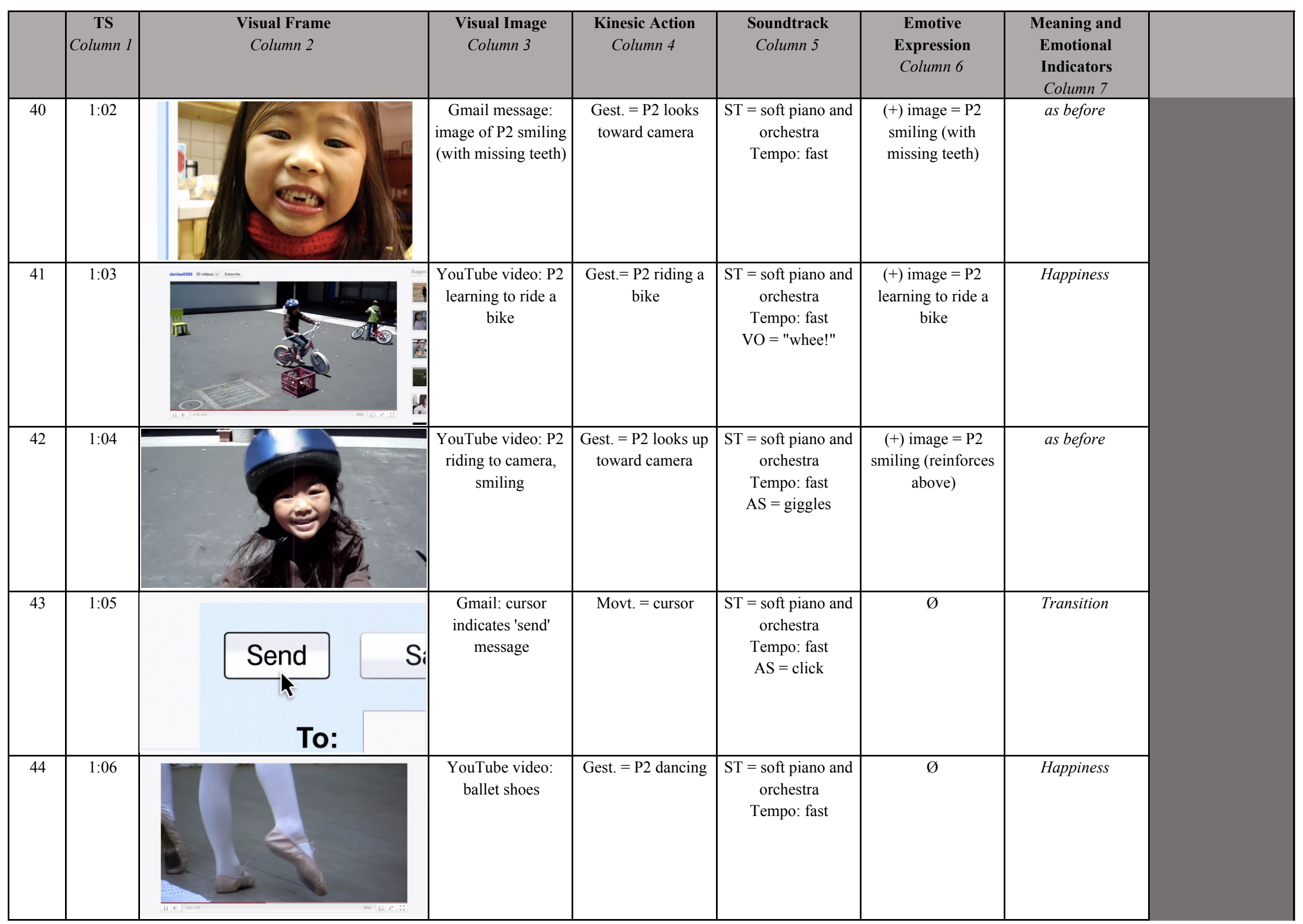




\begin{tabular}{|c|c|c|c|c|c|c|c|c|}
\hline & $\begin{array}{c}\text { TS } \\
\text { Column 1 }\end{array}$ & $\begin{array}{l}\text { Visual Frame } \\
\text { Column } 2\end{array}$ & $\begin{array}{c}\text { Visual Image } \\
\text { Column } 3\end{array}$ & $\begin{array}{l}\text { Kinesic Action } \\
\text { Column } 4\end{array}$ & $\begin{array}{l}\text { Soundtrack } \\
\text { Column } 5\end{array}$ & $\begin{array}{c}\text { Emotive } \\
\text { Expression } \\
\text { Column } 6\end{array}$ & $\begin{array}{l}\text { Meaning and } \\
\text { Emotional } \\
\text { Indicators } \\
\text { Column } 7\end{array}$ & \\
\hline 45 & $1: 06$ & & $\begin{array}{l}\text { YouTube video: P2 } \\
\text { taking ballet lessons }\end{array}$ & Gest. $=\mathrm{P} 2$ dancing & $\begin{array}{c}\mathrm{ST}=\text { soft piano and } \\
\text { orchestra } \\
\text { Tempo: fast }\end{array}$ & $\begin{array}{c}(+) \text { image }=\mathrm{P} 2 \\
\text { taking ballet lessons }\end{array}$ & as before & \\
\hline 46 & $1: 08$ & :t: You're growing up so fast| & $\begin{array}{l}\text { Gmail Subjectline: } \\
\text { "You're growing up } \\
\text { so fast" }\end{array}$ & Movt. = typing & $\begin{array}{c}\mathrm{ST}=\text { soft piano and } \\
\text { orchestra } \\
\text { Tempo: fast } \\
\text { AS = typing }\end{array}$ & $\begin{array}{l}(+) \text { text }=\text { "You're } \\
\text { growing up so fast" }\end{array}$ & Nostalgia & $\begin{array}{l}\text { PHASE 5: } \\
\text { CLOSURE }\end{array}$ \\
\hline 47 & 1:09 & $\begin{array}{l}\text { I didn't share with everyon } \\
\text { ow you already have one, } \\
\text { I've been writing you sil }\end{array}$ & $\begin{array}{c}\text { Gmail message } \\
\text { [BEGIN SCENE]: } \\
\text { "I've been writing } \\
\text { you..." }\end{array}$ & Movt. = typing & $\begin{array}{c}\mathrm{ST}=\text { soft piano and } \\
\text { orchestra } \\
\text { Tempo: fast } \\
\text { AS = typing }\end{array}$ & $\begin{array}{c}\text { BEGIN SCENE }(+) \\
\text { text1: "I've been } \\
\text { writing you..." }\end{array}$ & Nostalgia & \\
\hline 48 & $1: 11$ & $\begin{array}{l}\text { eryone at your party. } \\
\text { one, but this one was } \\
\text { since you were born. }\end{array}$ & $\begin{array}{l}\text { Gmail message } \\
\text { [CONT. SCENE]: } \\
\text { "... since you were } \\
\text { born" }\end{array}$ & Movt. = typing & $\begin{array}{c}\mathrm{ST}=\text { soft piano and } \\
\text { orchestra } \\
\text { Tempo: fast } \\
\text { AS = typing }\end{array}$ & $\begin{array}{l}\text { CONT. SCENE }(+) \\
\text { text } 2: \text { "... since you } \\
\text { were born." }\end{array}$ & Nostalgia & \\
\hline 49 & $1: 12$ & $\begin{array}{l}\text { II II I IIanIIIy. I ve I } \\
\text { I can't wait to share }\end{array}$ & $\begin{array}{c}\text { Gmail message } \\
\text { [CONT. SCENE]: "I } \\
\text { can't wait to share" }\end{array}$ & Movt. = typing & $\begin{array}{c}\mathrm{ST}=\text { soft piano and } \\
\text { orchestra } \\
\text { Tempo: fast }\end{array}$ & $\begin{array}{l}\text { CONT. SCENE (+) } \\
\text { text3: "I can't wait to } \\
\text { share" }\end{array}$ & Nostalgic & \\
\hline
\end{tabular}




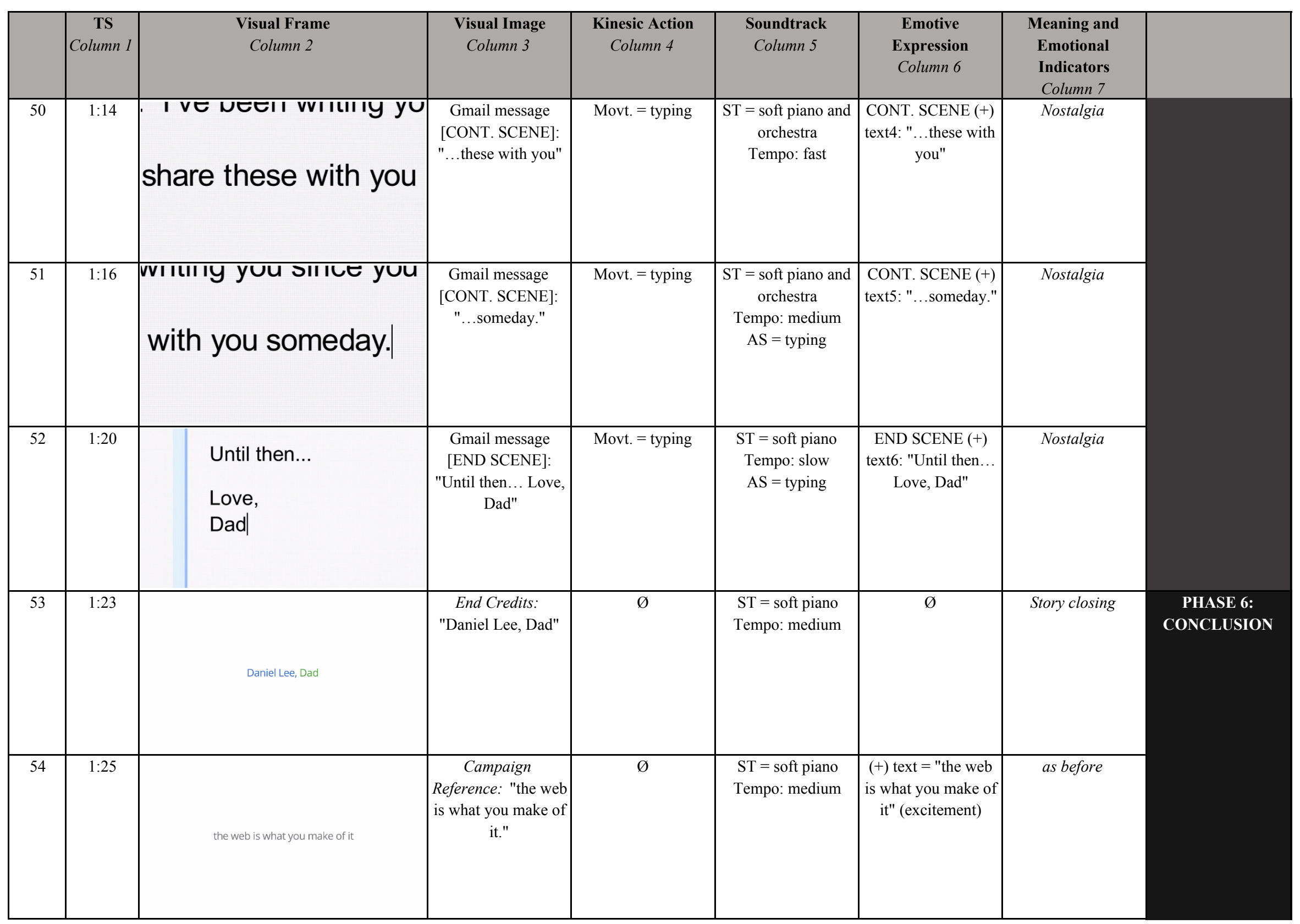




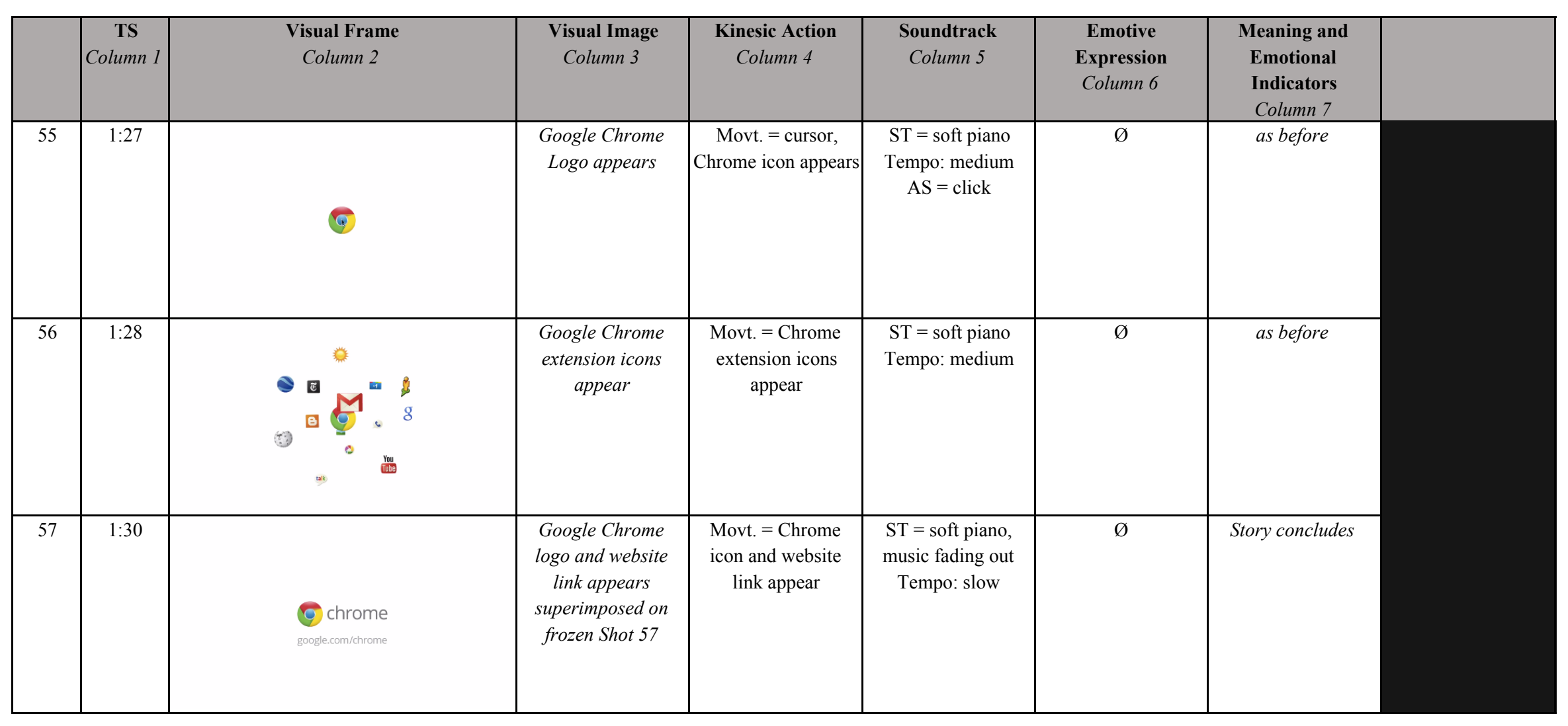

